\title{
WATER-RESOURCES INVESTIGATIONS OF THE U.S. GEOLOGICAL SURVEY
}

IN KANSAS--FISCAL YEARS 1979 AND 1980

\author{
U.S. GEOLOGICAL SURVEY \\ WATER-RESOURCES INVESTIGATIONS \\ OPEN-FILE REPORT 81-348
}

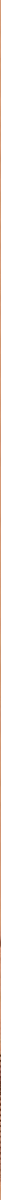




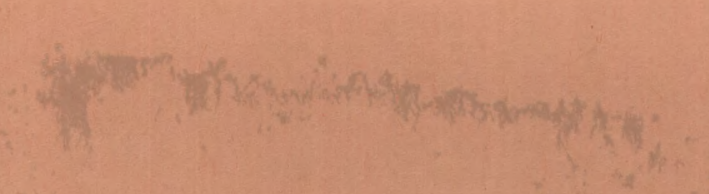


UNITED STATES

DEPARTMENT OF INTERIOR

GEOLOGICAL SURVEY

WATER-RESOURCES INVESTIGATIONS OF THE U.S. GEOLOGICAL SURVEY

IN KANSAS--FISCAL YEARS 1979 AND 1980

Compiled by H. E. McGovern and L. J. Combs

U.S. GEOLOGICAL SURVEY

Water-Resources Investigations

Open-File Report 81-348

Lawrence, Kansas

March 1981 


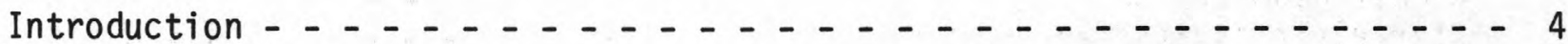

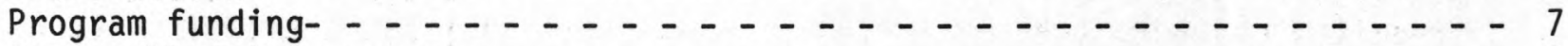

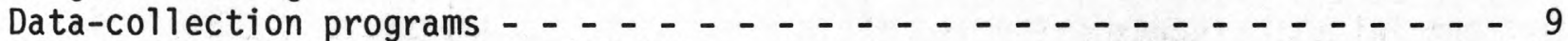

Surface-water stations (KS-001) - - - - - - - - - - - 10

Ground-water stations (KS-002) - . - . - . . . . . . - 16

Water-quality stations (KS-003) _ _ . - . - . - . . . - 20

Sediment stations (KS-004)- _ - _ - . - . . - . . - 26

Automated water-use data base (KS-007) . . . . . . . . . . . 27

Hydrologic data base (KS-086) _ . . . . . . . . . . . . 28

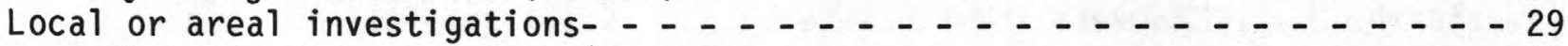

Flood-insurance studies (KS-006)- - - - - - - - - - - 29

Effect of urbanization, Wichita (KS-013) - . - . - . - . - 30

Water for municipal supply during droughts (KS-058) _ _ . - . - . 31

Discharge of saltwater from Permian rocks (KS-073) - - - - - - - 32

Saline discharge to Smoky Hill River (KS-074) - - - - - - - . - 33

Water resources in north-central Kansas (KS-075) - . - . - . - . 34

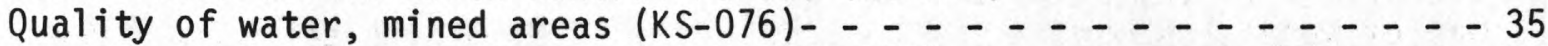

Sandstone aquifers, southwest Kansas (KS-079) - - - - - - - - - 36

Hydrology of mined lands (KS-081) _ _ _ . . . . . . . . 37

Geohydrology for water-supply planning (KS-082) _ . - . - . - . 38

Fluvial sediment, northeast Kansas (KS-083) - - . - . - . - - 39

Geohydrology of Arkansas River valley (KS-088) - _ - . - . - . - 40

Estimating ground-water withdrawals (KS-090) - . . . . . . . - 41

Glacial deposits, northeast Kansas (KS-091) - - . - . - . - - 42

"Equus beds" aquifer, central Kansas (KS-092) _ - . - . - . - 44

Kansas River bank stabilization (KS-095) - . - . . . . . . - 45

Water quality from urban runoff, Topeka (KS-096) - - . - - . - - 46

Wellington aquifer near Salina (KS-098) - - - - - - - - - - 47

Effects of strip mining, Linn, Miami, and Bourbon

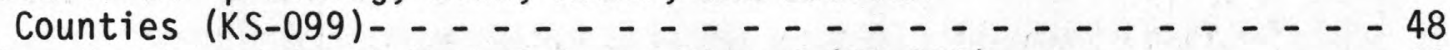

Models, North and South Fork Solomon Rivers (KS-100) - _ - . - . 49

Ground-water depletion maps, west-central Kansas (KS-105) - - - - - 50

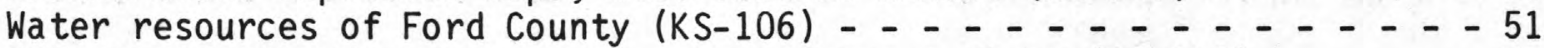

Effects of ground-water withdrawals, Arkansas River (KS-107)- - - - 52

Water quality, deep aquifers, western Kansas (KS-109) - _ - - . - 53

Geohydrology, Wellington Formation, Salina area (KS-110) - - - - - 54

Statewide or regional investigations - - . - . - . - . - . - - 55

Flood investigations (KS-010) - _ - . - . - . - . - 55

Streamflow characteristics (KS-011) - . - . - . - . - . 56

Kansas-0k lahoma Arkansas River Commission (KS-041) - - - - - - - 57

Short-term hydrologic investigations (KS-045) - - - . - - - - 58

Numerical models of streamflow (KS-059) _ . . - . . - . . - 59

Flood-hazard mapping (KS-062) _ _ _ _ . _ . . . . . . 60

Evaluation of Ground-Water-Quality Network (KS-077) _ - - - - - - 61

Potential for liquid-waste injection (KS-078) _ . . . . . . . 62

Aquifer-test evaluation (KS-093) _ . . . . . . . . . . . 63

High Plains aquifer study (KS-094) _ . . . . . . . . . - 64

Central Midwest aquifer study (KS-111) - . . . . . . . . - 65 


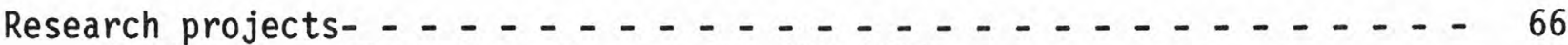

Sediment, active-channel geometry (KS-085) - - - . - - - - 66

Channel geometry of regulated streams (KS-087) - _ - - - - - - 67

Water-yield estimation (KS-089) _ _ _ _ _ . . . . . . 68

Streamflow characteristics, coal-lease areas (KS-097) - - - - - 69

Precipitation variability (KS-101) - - - - - . - - - - 70

Distribution information systems (KS-102) - . - . . - . - 71

List of reports published or released during 1979 and 1980

fiscal years - . . . . . . . . . . . . . . . . 72

Hydrologic-data stations in Kansas, 1980 water year _ . . . . . . . 75

\section{ILLUSTRATIONS}

Figure

Page

1. Map showing location of offices of the Water Resources Division, U.S.

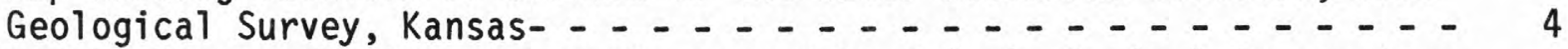

2. Map of Kansas showing areas not covered by U.S. Geological Survey topographic quadrangles, as of February $1979 \ldots \ldots$. 6

3. Pie diagram showing distribution of funding for the water-resources program of the U.S. Geological Survey in Kansas, fiscal years

1979 and 1980 ...

4. Map of Kansas showing location of complete-record surface-

water gaging stations, 1980 water year _ _ _ _ _ _ . - . - 12

5. Map of Kansas showing location of partial-record surface-water

gaging stations, 1980 water year _ _ _ _ . - . . . . - 14

6. Map of Kansas showing location of observation wells, 1980

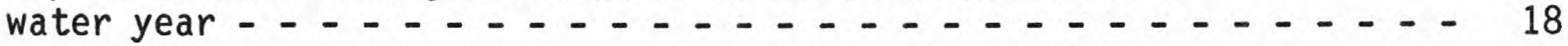

7. Map of Kansas showing location of surface-water-quality

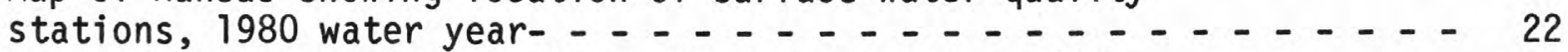

8. Map of Kansas showing location of ground-water-quality

sampling sites, 1980 water year _ _ _ _ _ . . . . . . 24

9. Diagram showing well-numbering system _... . . . . . . . . 77

TABLES

Table

Page

1. Complete-record surface-water gaging stations- - - _ - _ - - - 79

2. Partial-record surface-water gaging stations - _ . - . - . - 85

3. Ground-water-level observation wells _ _ . . . . . . . . - 91

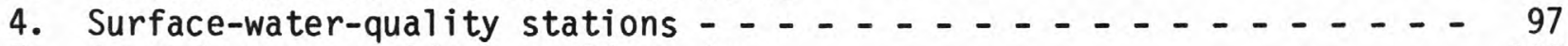

5. Ground-water-quality sampling sites- _ - . - . - . - . - 102 
The Organic Act of March 3, 1879, established the U.S. Geological Survey as a separate Bureau of the Department of the Interior. The Survey's principal mission became (1) the classification and survey of public 1ands, (2) the examination of the geologic structure and the mineral resources of the national domain, and (3) the determination of the water resources of the United States. Seven years later, in 1886, the first water-resources investigation by the U.S. Geological Survey in Kansas was completed by A. C. Peale. A cooperative program with the Kansas State Board of Irrigation and Surveys instituted the first stream-gaging stations in western Kansas during 1895. The gaging program later was extended to eastern Kansas in 1899.

From these early beginnings, the Water Resources Division of the U.S. Geological Survey has expanded its work in Kansas to meet the growing demand for scientific data by Federal, State, and local agencies for use in the planning and management of one of the State's most precious resource--water. The Kansas District of the Water Resources Division, with headquarters in Lawrence and subdistrict offices in Garden City and Sal ina ( $\mathrm{fig} .1$ ), investigates the occurrence, quantity, quality, distribution, and movement of surface and ground waters. Its activities include the systematic collection, analysis, and interpretation of data; the investigation of water demand for publ ic supply, industrial, domestic, and agricultural purposes; and the research and development of new techniques to improve the scientific basis of data collection and investigative principles.

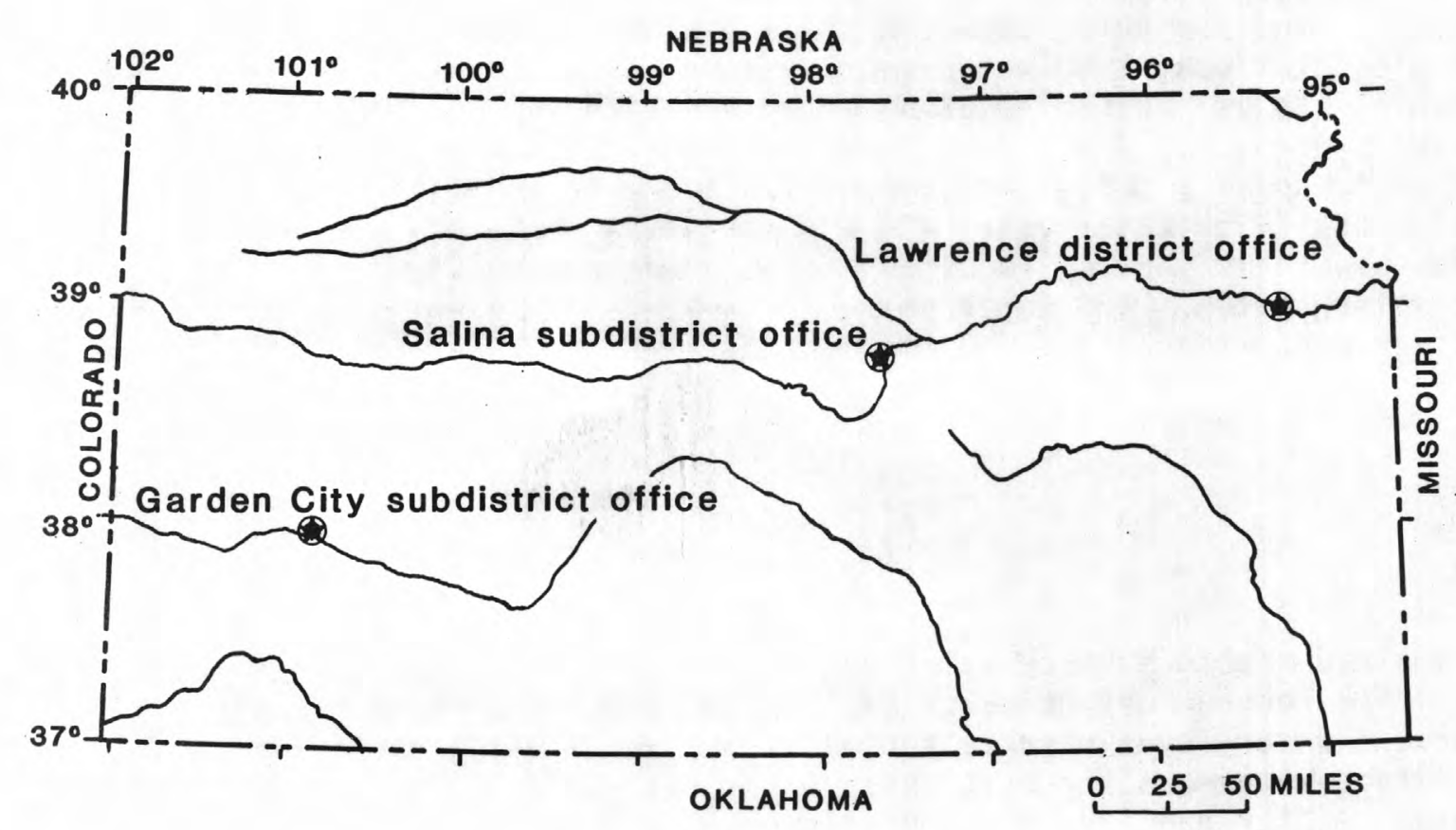

Figure 1.--Location of offices of the Water Resources Division, U.S. Geological Survey, Kansas. 
Water-resources data and the results of hydrologic investigations in Kansas are published or released either by the U.S. Geological Survey, by cooperating agencies, or by journals of technical and scientific organizations. Requests for such information and for publications resulting from past or present investigations of the U.S. Geological Survey in Kansas should be addressed to one of the following:

\author{
District Chief \\ U.S. Geological Survey \\ Water Resources Division \\ 1950 Avenue "A" - Campus West \\ Lawrence, Kansas 66045 \\ Phone: 913-864-4321
}

Subdistrict Chief

U.S. Geological Survey

Water Resources Division

206 Fulton Terrace

Garden City, Kansas 67846

Phone: $\quad 316-275-4123$
Subdistrict Chief U.S. Geological Survey Water Resources Division 211 W. Iron St., Rm. 209

Salina, Kansas 67401

Phone: 913-827-3330

The Topographic Division of the U.S. Geological Survey al so conducts an extensive mapping program in Kansas from its regional office in Rolla, Missouri. Standard topographic quadrangle maps published in the $71 / 2-$ and 15-minute series provide coverage for almost the entire State (see fig. 2). These maps may be purchased from:

Kansas Geological Survey

Publication Sales, 4th Floor

1930 Avenue A - Campus West

Lawrence, Kansas 66045

For additional information on the Topographic Division's mapping program in Kansas, write to:

National Cartographic Information Center

U.S. Geological Survey

507 National Center

Reston, Virginia 22092 


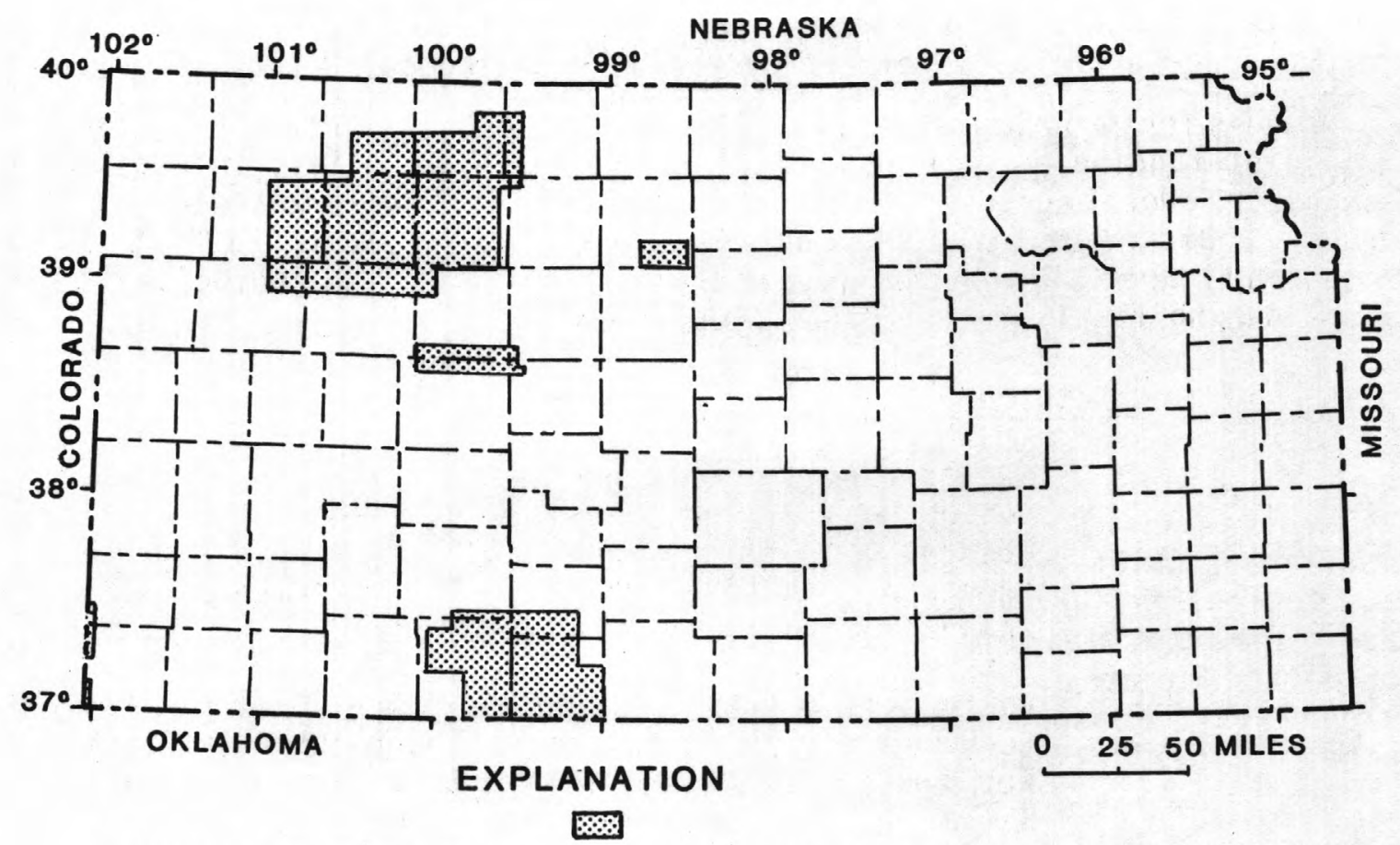

Area not covered by $71 / 2-$ or 15 -minute topographic quadrangles, as of February 1979

Figure 2.--Areas not covered by U.S. Geological Survey topographic quadrangles, as of February 1979.

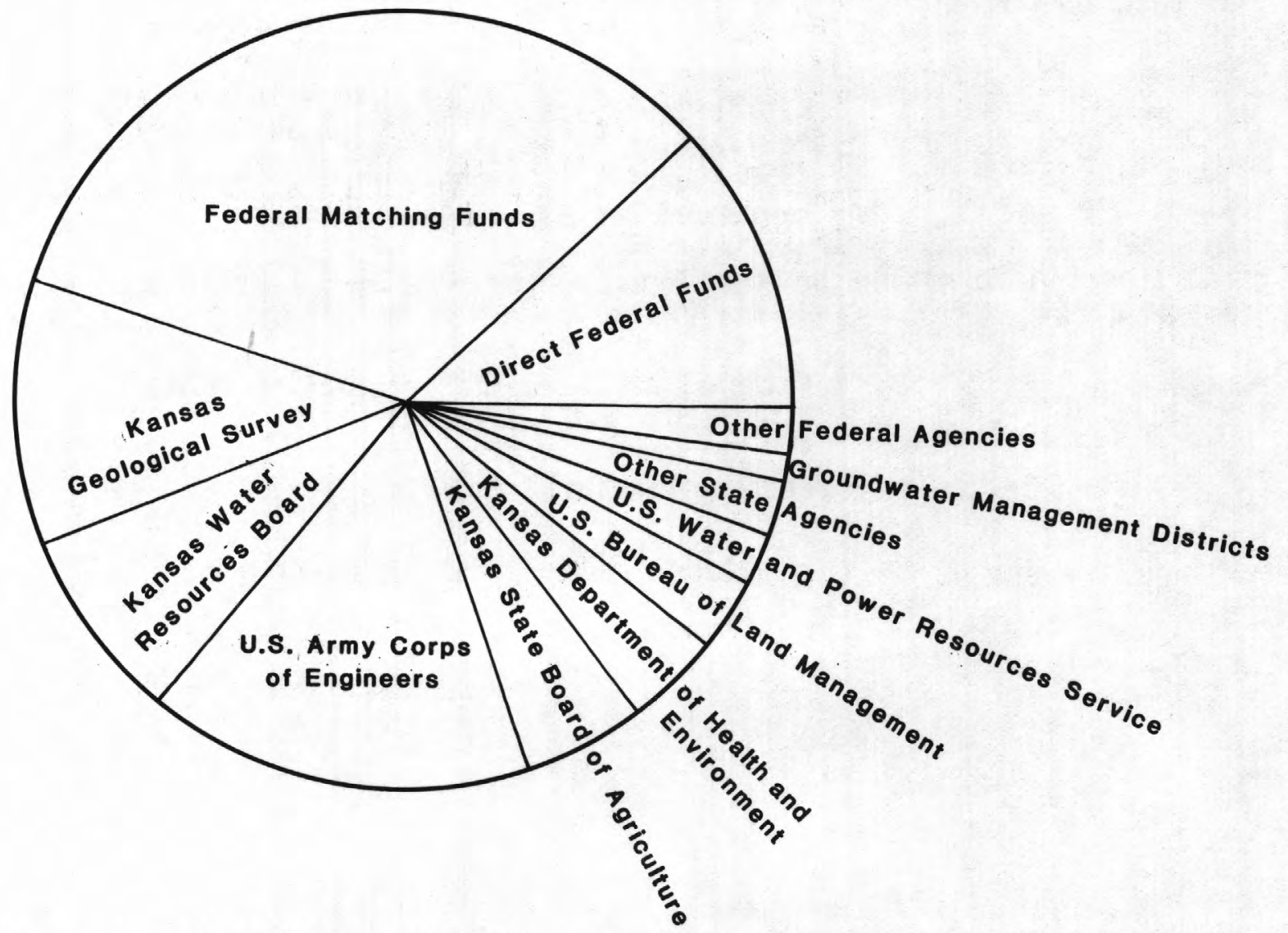

Figure 3.--Distribution of funding for the water-resources program of the U.S. Geological Survey in Kansas, fiscal years 1979 and 1980. 
Moneys for program operation of the Water Resources Division in Kansas come from joint-funding agreements with State and local agencies, transfer of funds from other Federal agencies, and direct Federal allotments to the U.S. Geological Survey . Distribution of funding for program operation in FY79-80 is illustrated in figure 3. Those agencies cooperating with the U.S. Geological Survey in Kansas during the 1979 and 1980 fiscal years were:

\title{
State and local agencies
}

\author{
Kansas Geological Survey \\ Kansas Water Resources Board \\ Kansas State Board of Agriculture \\ Kansas Department of Health and Environment \\ Kansas Department of Transporation \\ City of Wichita \\ Western Kansas Groundwater Management District No. 1 \\ Southwest Kansas Groundwater Management District No. 3 \\ Northwest Kansas Groundwater Management District No. 4 \\ Kansas-Ok1ahoma Arkansas River Commission
}

\section{Federal agencies}

U.S. Department of Agriculture, Soil Conservation Service

U.S. Department of Army, Corps of Engineers

U.S. Department of Housing and Urban Development

U.S. Department of Interior, Bureau of Land Management

U.S. Department of Interior, Fish and Wildi ife Service

U.S. Department of Interior, Office of Surface Mining Reclamation and Enforcement

U.S. Department of Interior, Water and Power Resources Service 
The following projects were funded for fiscal years 1979 and 1980 in the Kansas District:

\begin{tabular}{|c|c|}
\hline $\begin{array}{l}001 \\
002 \\
003 \\
004 \\
006 \\
007 \\
010 \\
011 \\
013 \\
041 \\
045 \\
058 \\
059 \\
062 \\
073 \\
075 \\
076 \\
077 \\
078 \\
079 \\
081 \\
082 \\
083 \\
085 \\
086 \\
087 \\
088 \\
089 \\
090 \\
091 \\
092 \\
093 \\
094 \\
095 \\
096 \\
097 \\
098 \\
099 \\
100 \\
101 \\
102 \\
105 \\
106 \\
107 \\
109 \\
110 \\
111\end{array}$ & $\begin{array}{l}\text { Surface-water stations } \\
\text { Ground-water stations } \\
\text { Water-quality stations } \\
\text { Sediment stations } \\
\text { Flood-insurance studies } \\
\text { Water-use data base } \\
\text { Flood investigations } \\
\text { Streamflow characteristics } \\
\text { Urban runoff, Wichita } \\
\text { Kansas-Oklahoma Arkansas River } \\
\text { Short-term hydrologic investigations } \\
\text { Municipal supply during droughts } \\
\text { Streamflow models } \\
\text { Flood-hazard mapping } \\
\text { Saltwater, Permian rocks } \\
\text { Water resources, north-central Kansas } \\
\text { Water-quality mined areas, southeast Kansas } \\
\text { Ground-Water-Quality Network evaluation } \\
\text { Liquid-waste disposal, Arbuckle Group } \\
\text { Sandstone aquifer, southwest Kansas } \\
\text { Mined-land hydrology, southeast Kansas } \\
\text { Geohydrology for planning, western Kansas } \\
\text { Fluvial sediment, northeast Kansas } \\
\text { Sediment, active-channel geometry } \\
\text { Hydrologic-data base, southwest Kansas } \\
\text { Channel geometry, regulation } \\
\text { Geohydrology, Arkansas River valley } \\
\text { Water-yield estimation } \\
\text { Estimated ground-water withdrawals } \\
\text { Glacial deposits, northeast Kansas } \\
\text { "Equus beds" aquifer } \\
\text { Aquifer-test evaluation } \\
\text { High Plains aquifer study } \\
\text { Stabilization, Kansas River } \\
\text { Urban storm-water quality, Topeka } \\
\text { Channel geometry - coal areas } \\
\text { Wellington aquifer near Salina } \\
\text { Coal hydrology, east-central Kansas } \\
\text { Models, North \& South Fork Solomon Rivers } \\
\text { Precipitation variability } \\
\text { Information systems, Kansas } \\
\text { Ground-water depletion maps } \\
\text { Water resources of Ford County } \\
\text { Ground-water withdrawals, Arkansas River } \\
\text { Water quality, deep aquifers, western Kansas } \\
\text { Geohydrology, Wellington Formation, Salina area } \\
\text { Central Midwest aquifer study }\end{array}$ \\
\hline
\end{tabular}

Subsequent sections of this report describe these projects under the general headings of: (1) data-collection programs, (2) local or areal investigations, (3) statewide or regional investigations, and (4) research projects. 
Throughout its long history of service to the people of Kansas, the primary mission of the Water Resources Division has remained the same--the comprehensive and systematic collection of hydrologic data and the timely release of such data for public use. To help provide this valuable service, a network of hydrologic-data stations is maintained throughout Kansas to obtain records of (1) stage, discharge, chemical quality, and sediment yield of streams; (2) stage, content, and chemical quality of lakes and reservoirs; and (3) water levels and chemical quality of ground water.

Hydrologic data collected in Kansas as part of the water-resources-data network are published annually in a comprehensive report entitled "U.S. Geological Survey Water-Data Report KS-80-1 (orKS-80-2)." The report number identifies the two-letter state abbreviation (KS), the last two digits of the water year $(80)$, and the volume number (1, Missouri River basin; 2, Arkansas River basin). Water-data reports are available from the U.S. Geological Survey office in Lawrence, Kansas, or from the National Technical Information Service, U.S. Department of Commerce, Springfield, Virginia 22161.

Hydrologic data also are stored in both current and historical computer files in the U.S. Geological Survey's National Water-Data Storage and Retrieval System (WATSTORE). The data are available for water planning and management in machine-readable form, computer-printed tables or graphs, statistical analyses, and digital plots. Local assistance in the acquisition of computer services is available from the Kansas District office in Lawrence. 
PROJECT TITLE: Surface-water stations

PROJECT NUMBER: KS-001

COOPERATING AGENCY: Multifunded

PROJECT CHIEF : C. 0 . Geiger

Problem -- Surface-water information is needed for purposes of surveillance, planning, design, hazard warning, operation, and management in such water-related fields as water supply, hydroelectric power, flood control, irrigation, floodplain management, and water-resources development. To provide this information, an appropriate and comprehensive data base is necessary.

Objective -- Collect surface-water data sufficient to satisfy needs for current-purpose uses, such as (1) assessment of water resources, (2) operation of reservoirs or industries, (3) forecasting, (4) disposal of wastes and pollution controls, (5) discharge data to accompany water-quality measurements, (6) compact and legal requirements, and (7) research or special studies.

Collect data necessary for analytical studies to define, for any location, the statistical properties of, and trends in, the occurrence of water in streams, lakes, and reservoirs for use in planning and design.

Approach-- A network of gaging stations is maintained to provide surfacewater data for management and operation, for determination of long-term trends, and for research and special studies. Data are collected on stage and discharge of streams or canals, and on stage, surface area, and content of lakes and reservoirs.

Progress -- The network of stations is revised periodically to ensure the collection of meaningful and worthwhile data. Figures 4 and 5 and tables 1 and 2 (given at the conclusion of this report) list the surface-water stations in operation during the 1980 water year. 
Complete-record stations (shown in figure 4 and listed in table 1) provide continuous data for determination of flow or volume of water in storage on a daily, monthly, or annual basis. Partial-record stations (shown in figure 5 and listed in table 2) provide limited data collected systematically to record low-flow (base-flow) discharges and crest-stage (flood-stage) or maximum discharges on additional streams at selected locations.

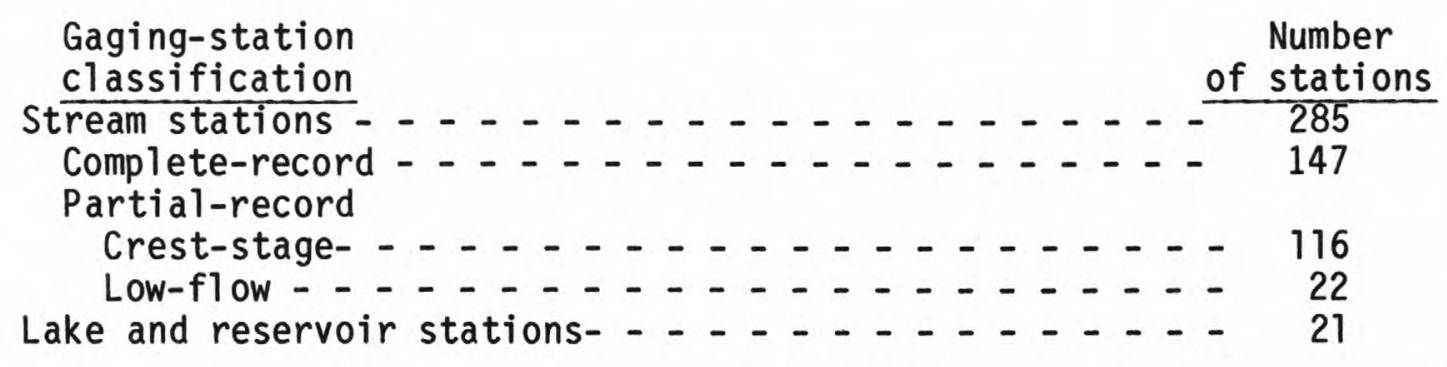

Plans--Data will be collected at 143 continuous streamflow sites, 22 reservoir stations, 47 crest-stage gages, and 23 low-flow sites during the 1981 water year.

Reports published or released--See numbers 31, 36, and 37 in "List of Reports... . 


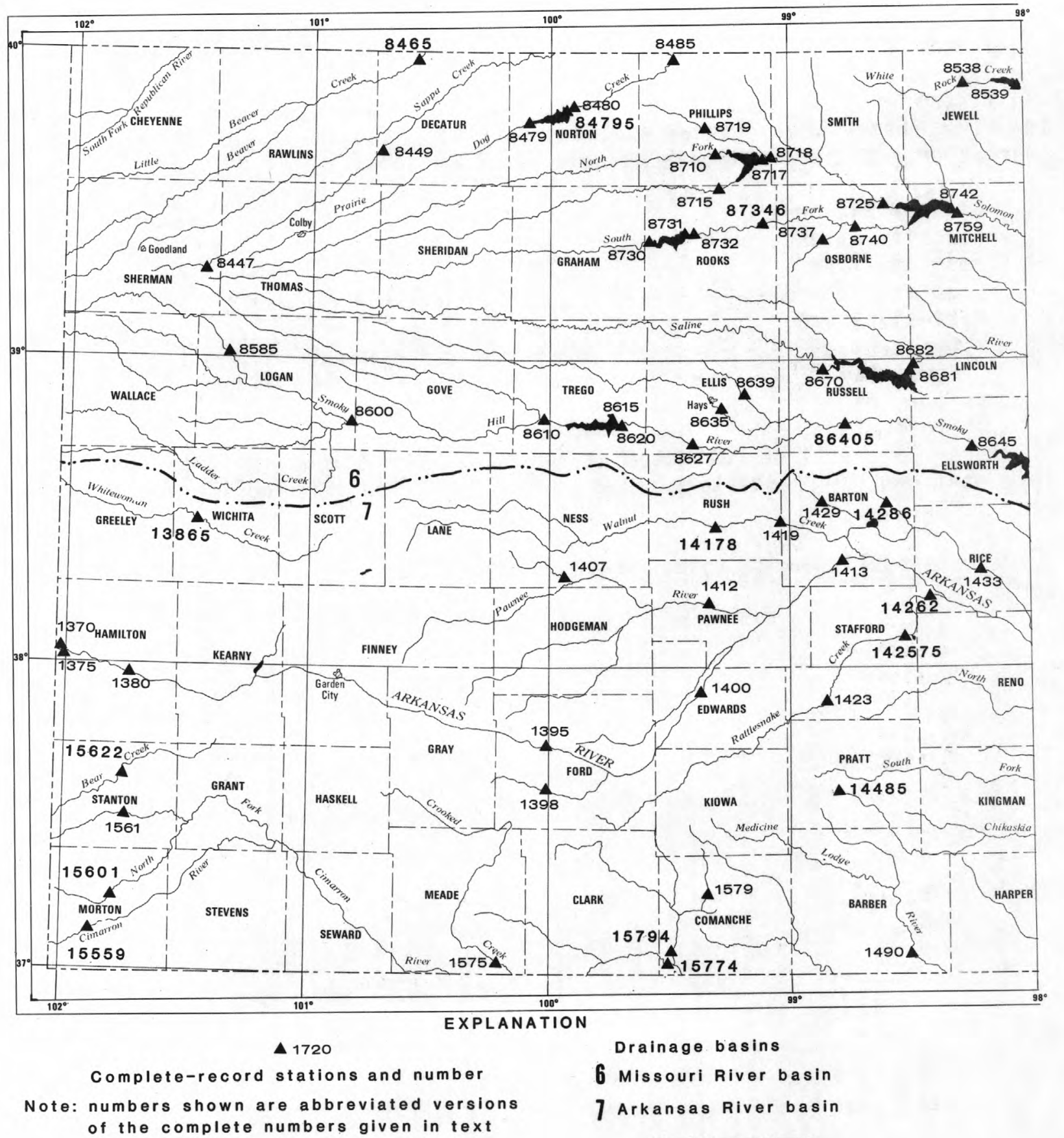

Basin boundary 


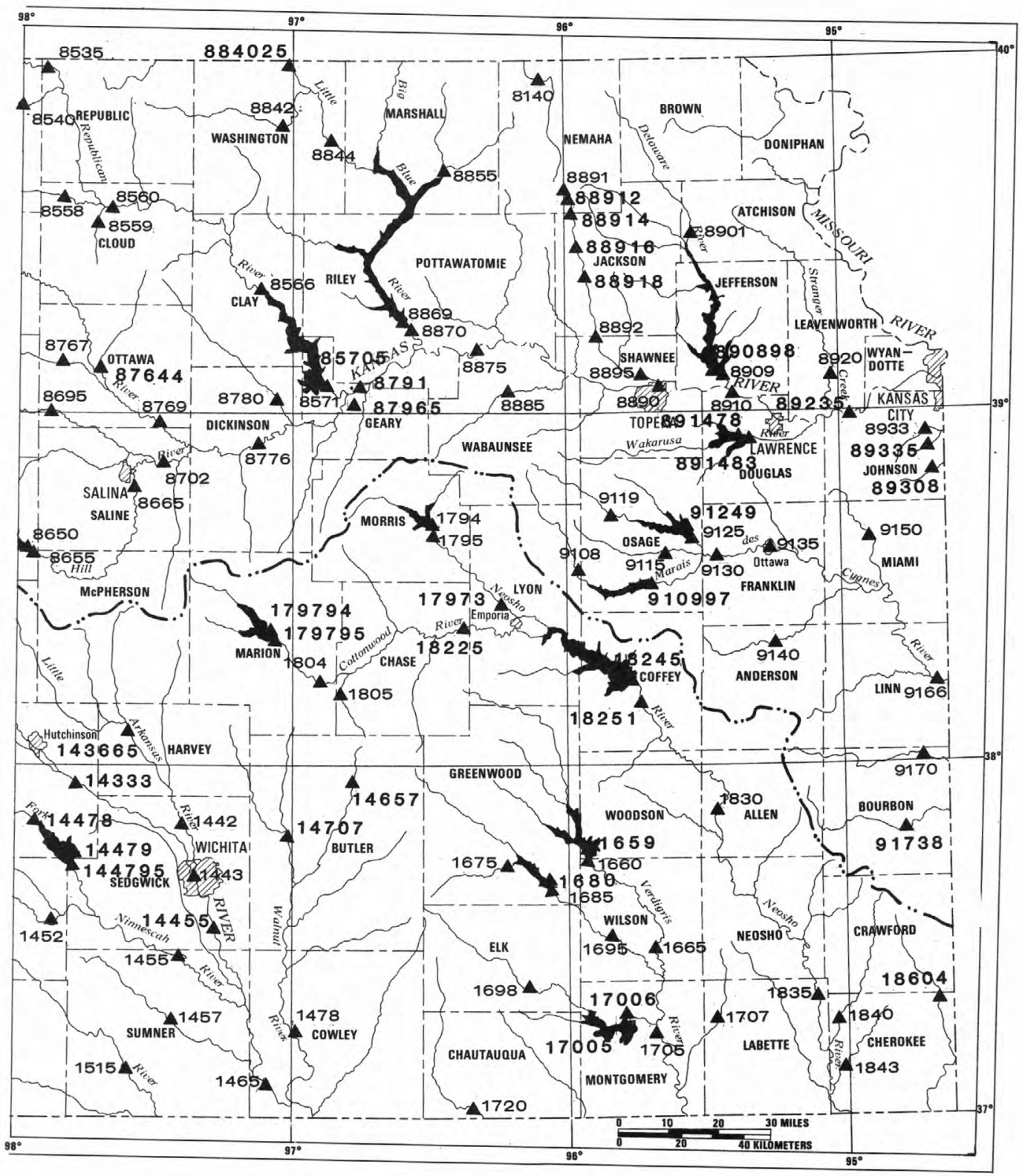

Figure 4.--Location of complete-record surface-water gaging stations, 1980 water year. Stations are listed in table 1. 


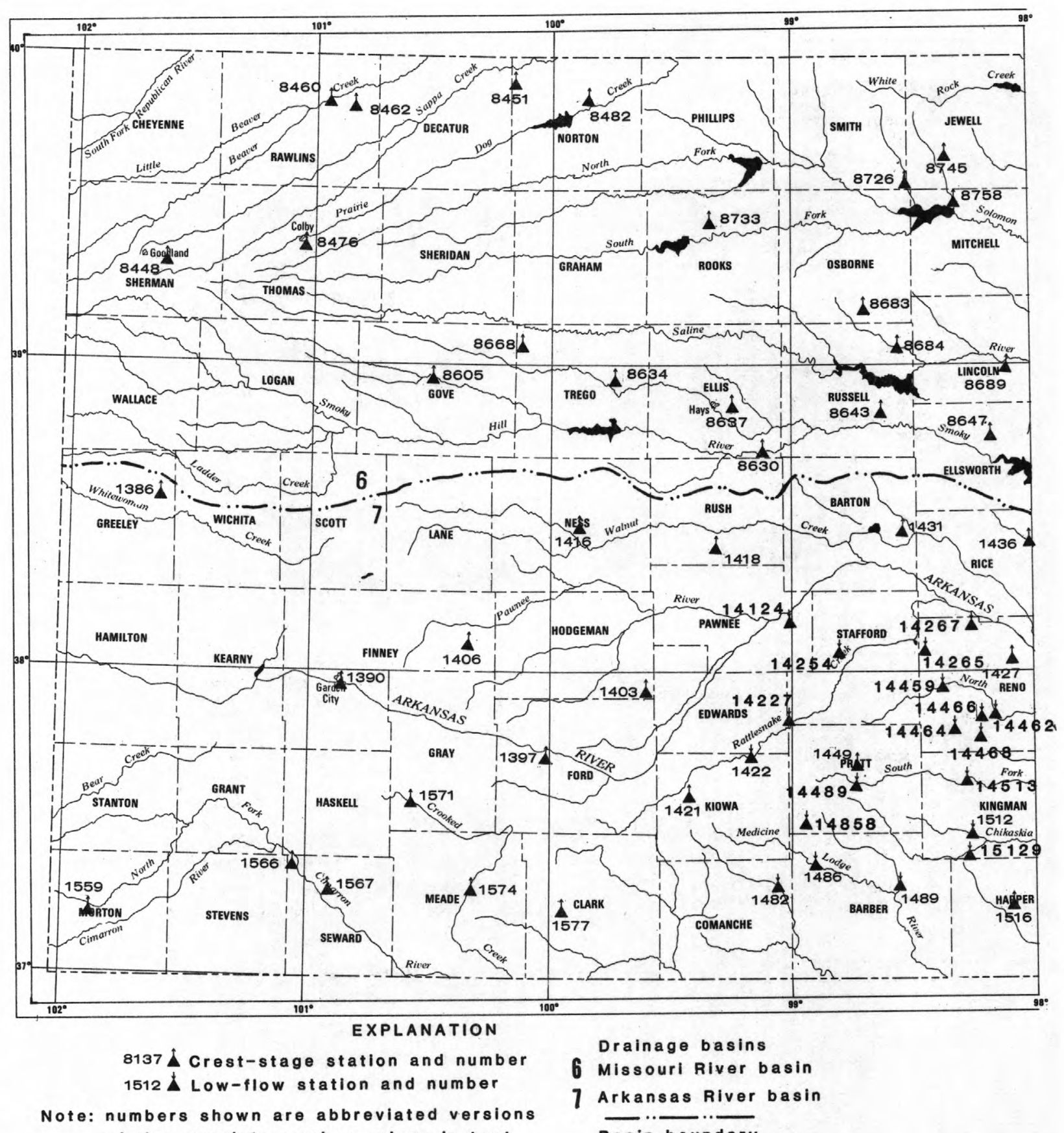

of the complete numbers given in text

Basin boundary 


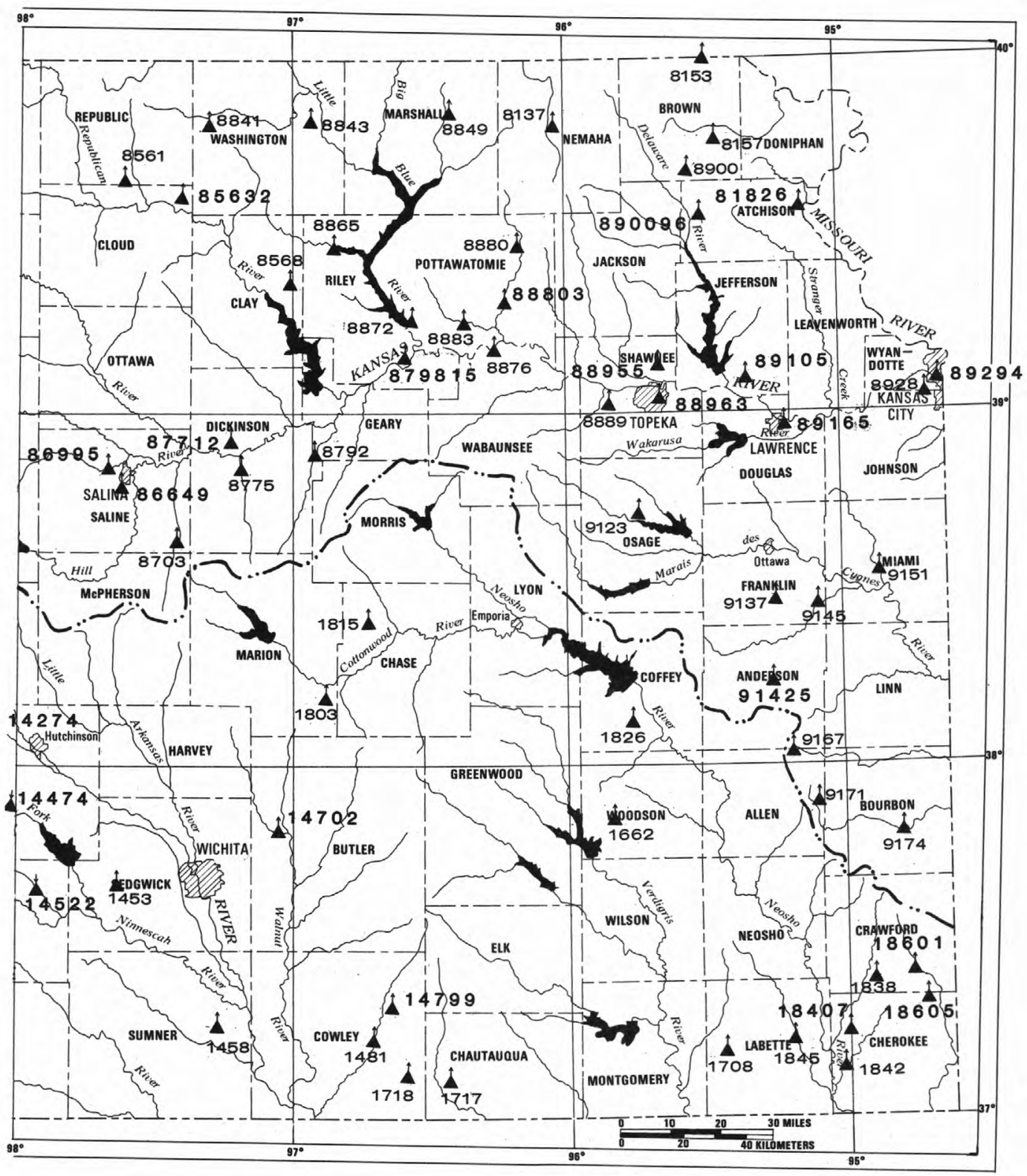

Figure 5.--Location of partial-record surface-water gaging stations, 1980 water year. Stations are listed also in table 2. 
STATE WIDE

PROJECT TIITE: Ground-water stations

PROJECT NUMBER: KS-002

COOPERATING AGENCY: Multifunded

PROJECT CHIEF : C. 0 . Geiger

Problem -- Long-term water-level records are needed (1) to evaluate the effects of climatic variations on the recharge to and discharge from the groundwater systems in Kansas, (2) to provide a data base from which to measure the effects of development, (3) to assist in the prediction of future supplies, and (4) to provide data for management of the resource.

Objective -- Collect water-level data sufficient to provide a minimum longterm database so that the general response of the hydrologic system to natural climatic variations and induced stresses is known and so that potential problems can be defined early enough to allow proper planning and management.

Provide a data base against which the short-term records acquired in areal studies can be analyzed. This analysis must (1) provide an assessment of the ground-water resources, (2) allow predictions of future conditions, (3) detect and define pollution and supply problems, and (4) provide the data base necessary for management of the resource.

Approach -- A network of observation wells is measured to provide a data base for monitoring the general response of ground-water systems to natural climatic variations and to stresses of pumpage. A long-term record of water-level measurements, in conjunction with a determination of the hydrologic system, provides data for proper planning and management. 
Progress -- Water levels were measured in 470 observation wells during the $1 \overline{980}$ water year (shown in figure 6 and listed in table 3 at the conclusion of this report) on a regularly scheduled basis ranging from continuous (recording gage) to annually. The network of wells and the regularity of measurements are designed to provide sufficient water-level data to establish a minimum long-term data base.

In addition, water levels in about 1,475 wells are measured annually in western Kansas with support from personnel of the Division of Water Resources, Kansas State Board of Agriculture. Annual reports are published to show the water-level change resulting from ground-water withdrawals, principally irrigation (see number 24 in "List of Reports...").

The water levels in numerous other wells are measured for short periods as part of interpretive hydrologic studies.

Plans -- Water-level measurements will be obtained from approximately 1,950 wells during the 1981 water year.

Reports published or released -- See numbers $24,26,31,36$, and 37 in "List of Reports..."." 


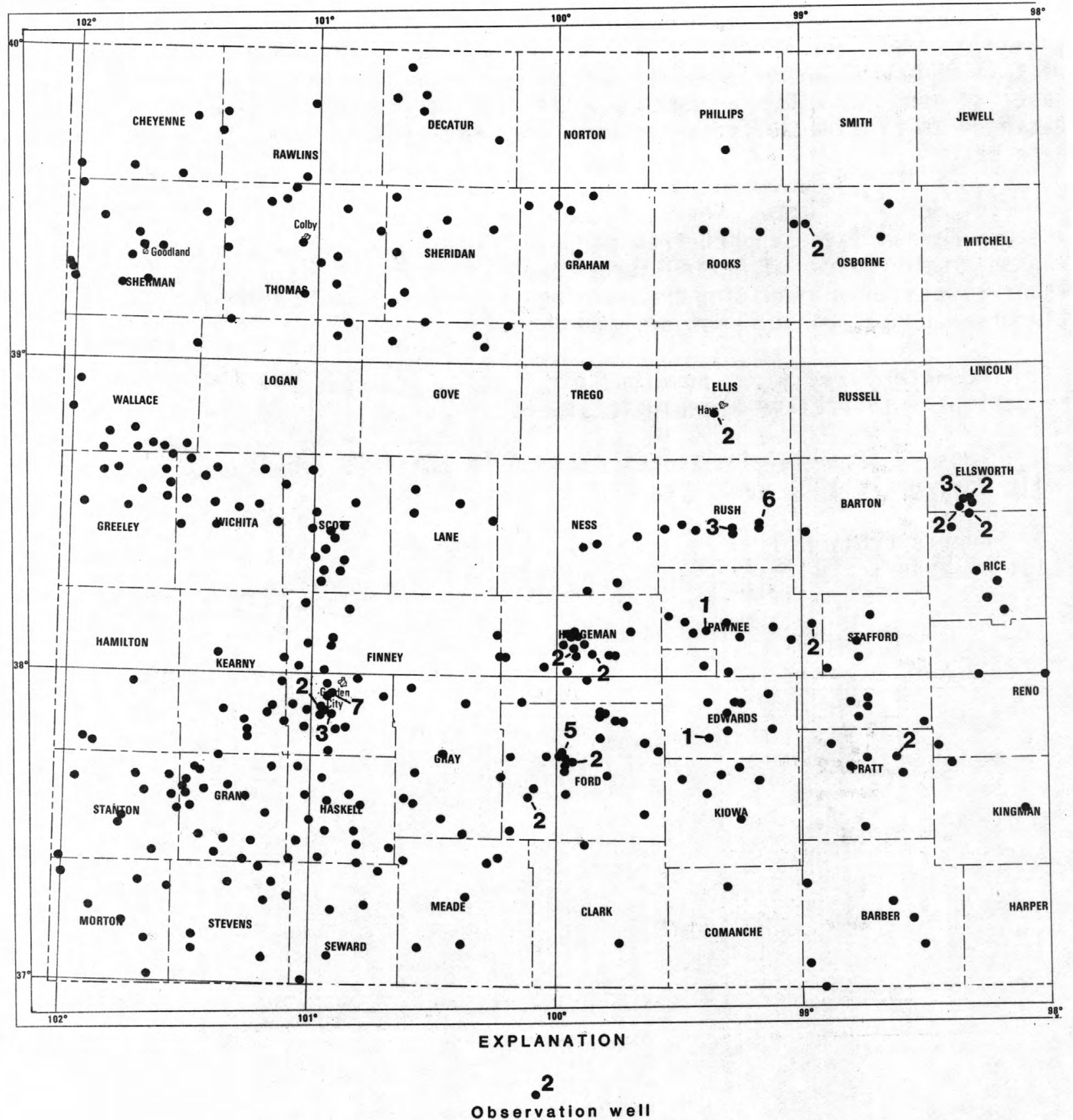

Number indicates more than one well at this site 


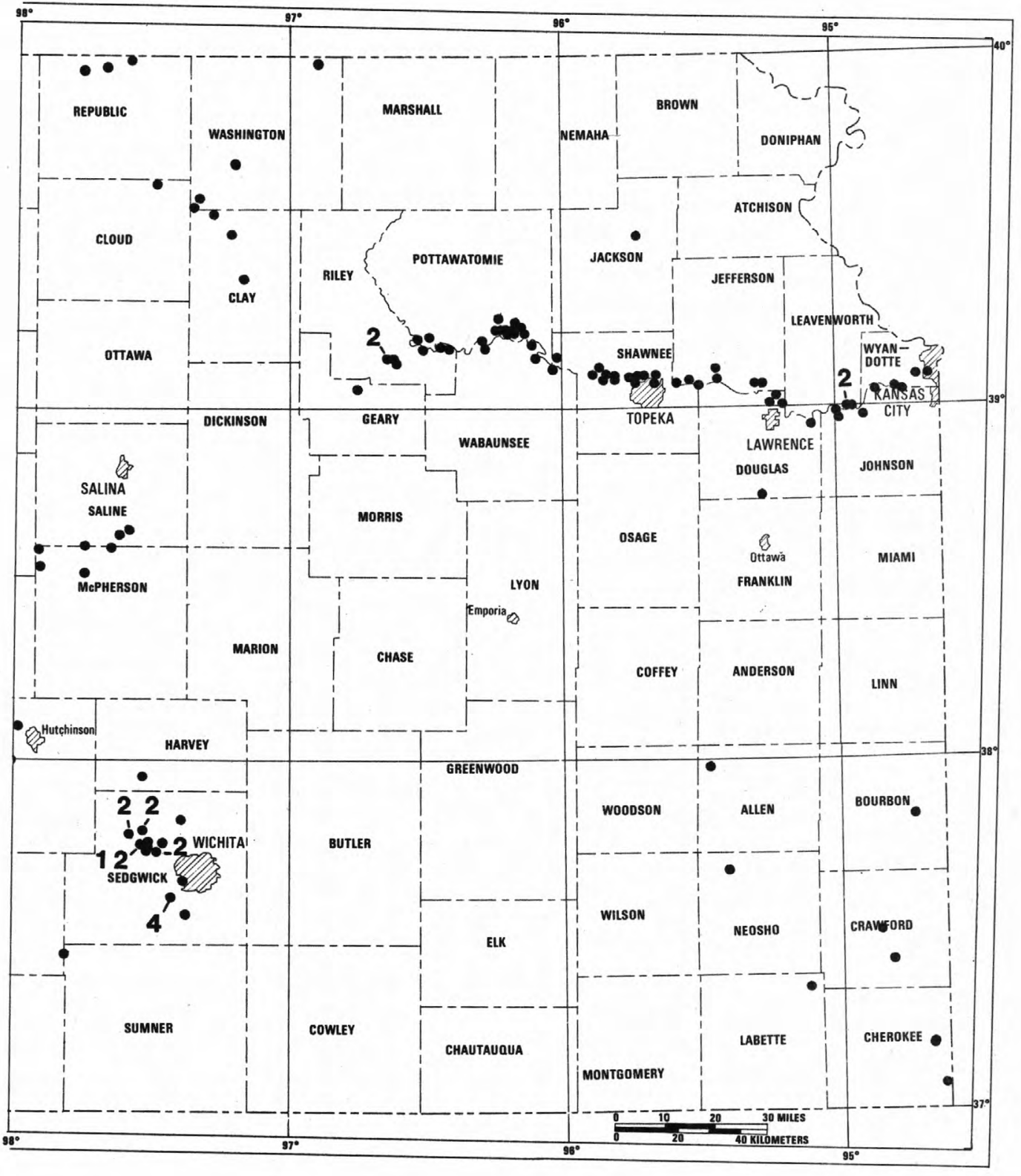

Figure 6.--Location of observation wells, 1980 water year. Well locations are listed also in table 3 . 
PROJECT TITLE: Water-quality stations

PROJECT NUMBER: KS-003

COOPERATING AGENCY: Multifunded

PROJECT CHIEF: C. 0 . Geiger

Problem -- Water-resource planning and water-quality assessment require a national data base of relatively standardized information. For intelligent planning and realistic assessment of the water resource, the chemical and physical quality of the rivers, streams, lakes, and reservoirs, as well as major ground-water aquifer systems, must be defined and monitored.

Objective -- To provide a national bank of water-quality data for State, local, and Federal planning and action programs, and to provide data for the Federal management of interstate waters.

Approach -- Surface-water-quality stations are maintained in Kansas to monitor long-term and short-term trends related to changes in streamflow, reservoir operation, and local or regional pollution. In addition, a collection network of surface-water-quality data, identified as the National Stream-Quality Accounting Network (NASQAN), is designed by the U.S. Geological Survey to meet many of the information demands of agencies or groups involved in national or regional water-quality planning and management. Primary objectives of the network are to depict areal variability of streamflow and water-quality conditions nationwide on a year-by-year basis and to detect and assess long-term changes in streamflow and water quality. Water samples are collected also at a few regular surface-water stations, as a Federal interagency activity, for monitoring the concentration and distribution of pesticides in streams where potential contamination could result from continued or future application of the commonly used insecticides or herbicides. As part of a nationwide sampling of major drainage basins, water also is collected at one station to be analyzed for radioisotopes. 
Approach -- continued.

Water-quality data are collected from a network of wells to determine the chemical characteristics of ground water in the principal aquifers and to assess the suitability of the water for use in domestic and municipal supplies. The information also is collected to establish an adequate data base for monitoring change in water quality according to the provisions of the Safe Drinking Water Act, 1975. Other samples of ground water from various geologic formations at specific locations are analyzed for interpretive hydrologic investigations.

Progress -- Data were collected on a routinely scheduled basis (generally near surface-water gages) at 131 complete-record stations and 2 lakes (shown in figure 7 and listed in table 4 at the end of this report) during the 1980 water year. Water-quality samples collected on a routine basis at 79 stations generally are analyzed for inorganic chemical constituents; samples at selected sites also are analyzed for pesticide, radiochemical, biologic, and bacteriologic data as part of interpretive hydrologic investigations.

Collection and analysis of water samples from 430 wells (shown in figure 8 and listed in table 5 at the end of this report) were made in the 1980 water year as part of a statewide network for determining the existing chemical characteristics of ground water in the principal aquifers and for detecting pollution.

Plans -- Water-quality data will be collected at 131 streamflow sites and 2 lake sites on a regularly scheduled basis during the 1981 water year. Samples collected at 79 of these sites will be analyzed for inorganic chemical constituents. Chemical analyses will be conducted also on samples from 430 wells in the Kansas Ground-Water-Quality Monitoring Network .

Reports published or released -- See numbers 31, 36, and 37 in "List of Reports... 


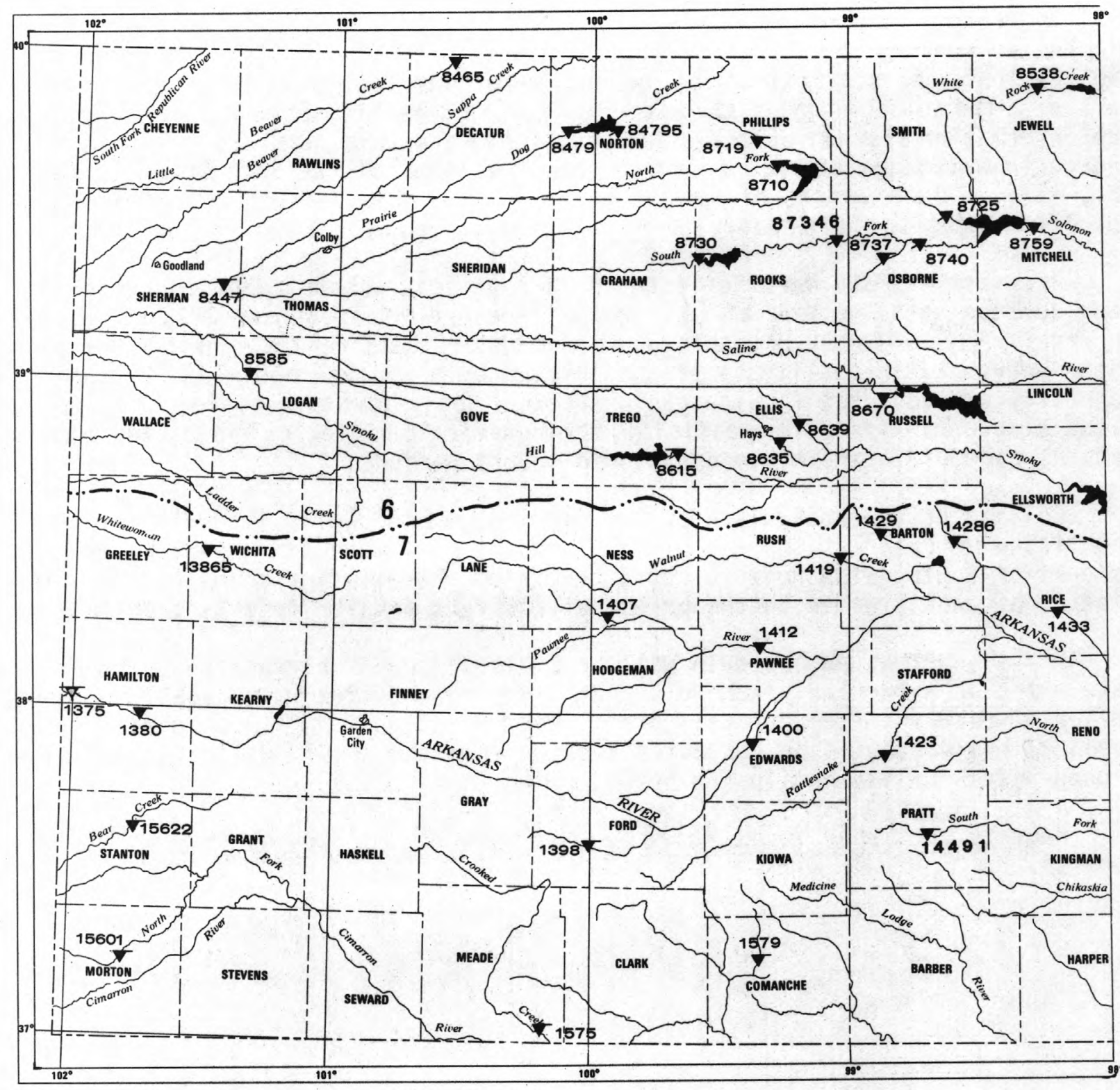

\section{EXPLANATION}

Chemical
$\nabla$ Temperature $\nabla$ Sediment Note: numbers shown are abbreviated versions of the complete numbers given in text

Drainage basin

6 Missouri River basin

1 Arkansas River basin

Basin boundary 


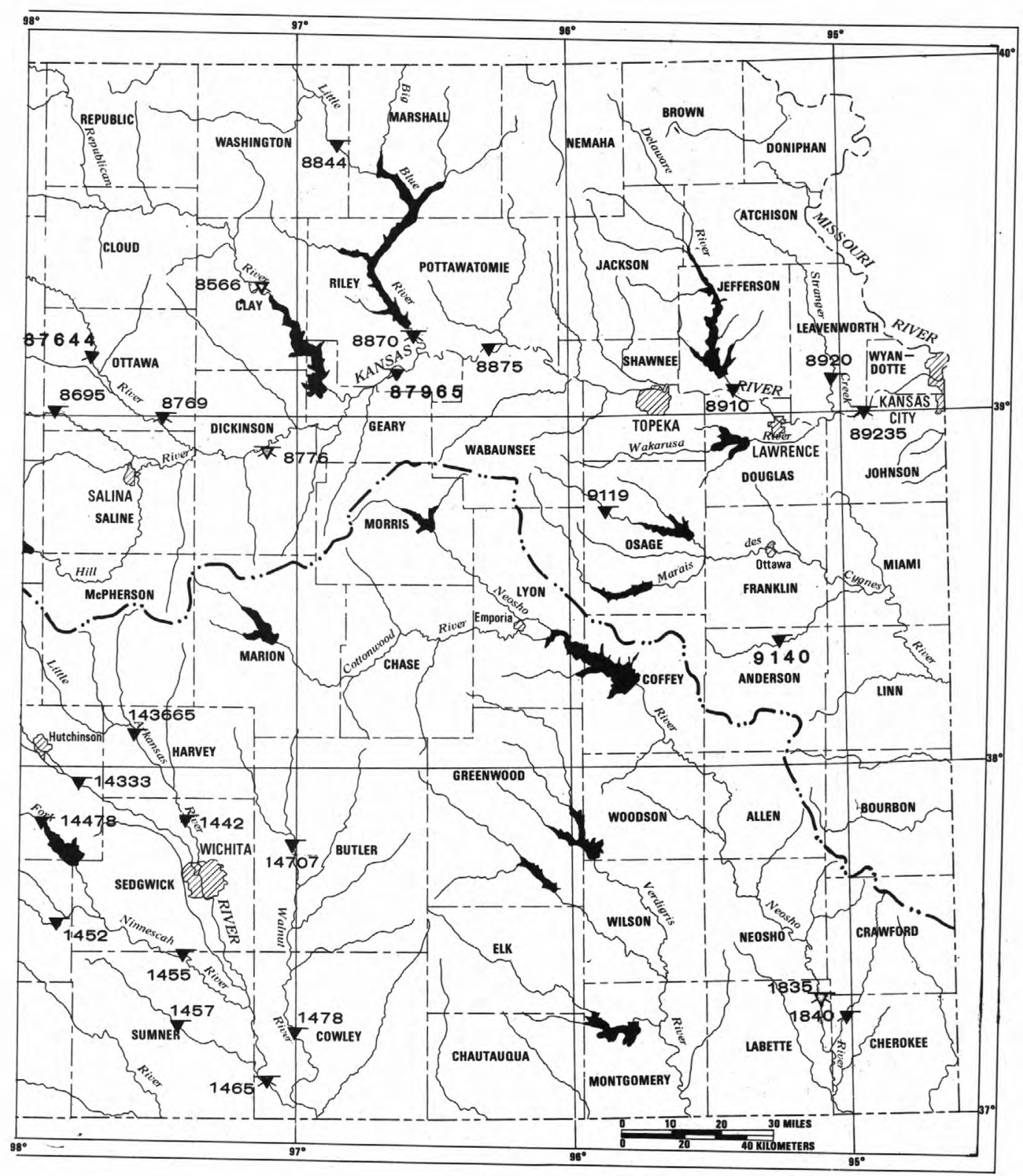

Figure 7.--Location of surface-water-quality stations, 1980 water year. Stations are listed also in table 4. 


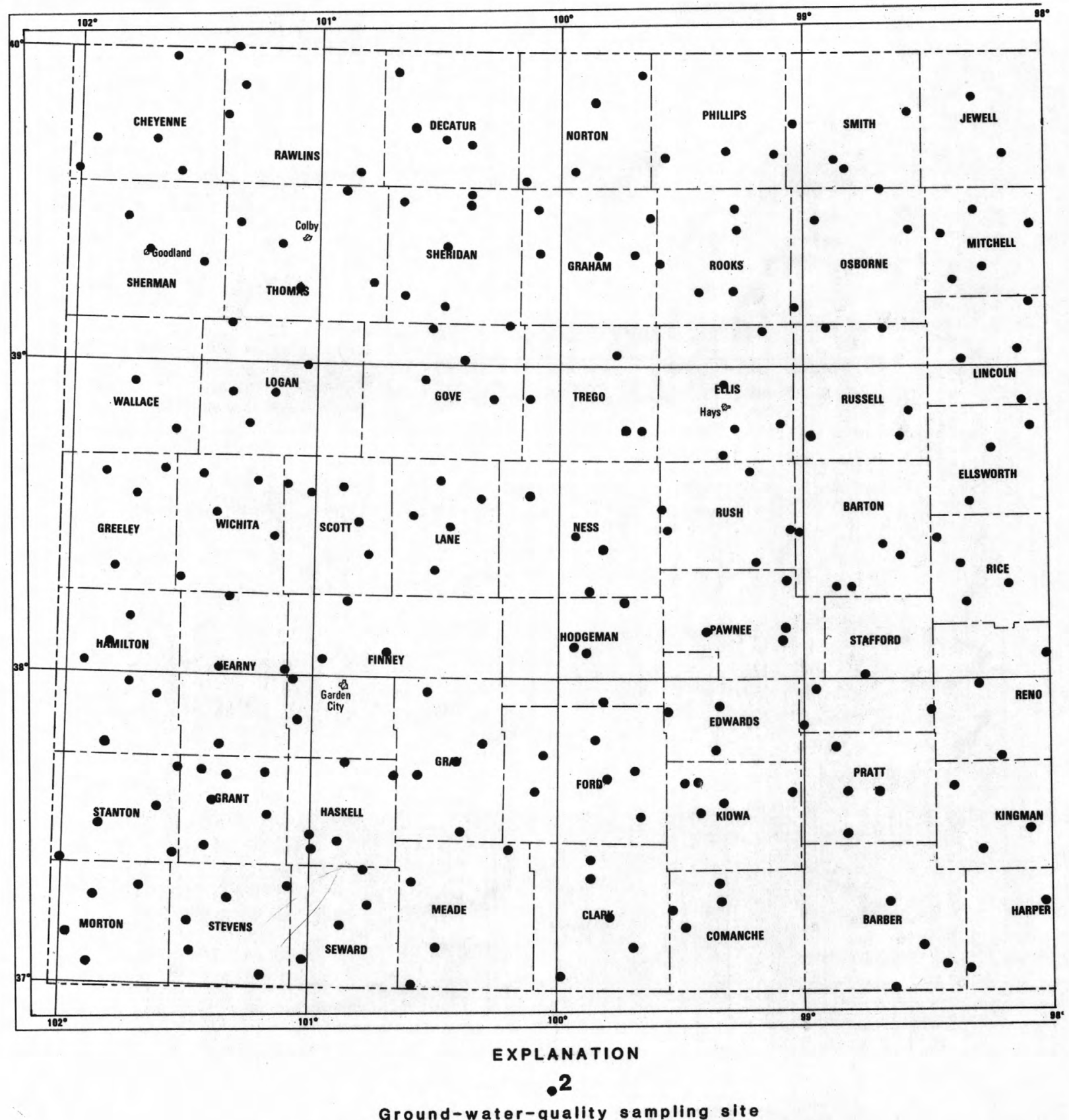

Ground-water-quality sampling site

Number indicates more than one well at this site 


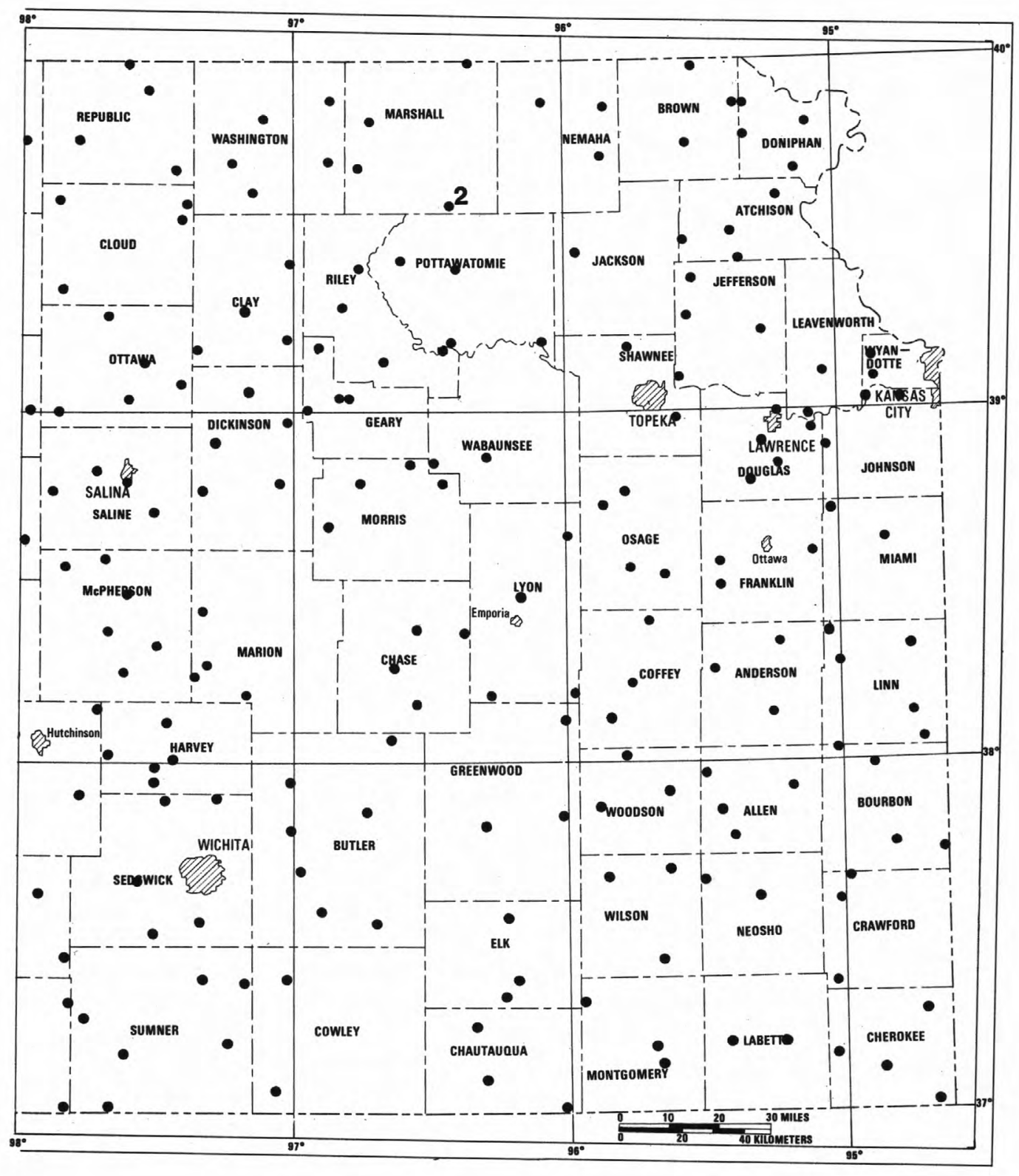

Figure 8.--Location of ground-water-quality sampling sites, 1980 water year. Sampling sites are listed also in table 5 . 
STA TE WIDE

PROJECT TITLE: Sediment stations

PROJECT NUMBER: KS-004

COOPERATING AGENCY: Multifunded

PROJECT CHIEF : C. 0 . Geiger

Problem -- Sediment concentrations and discharges in rivers and streams must be defined and monitored in order to make a comprehensive water-quality assessment of the Nation's water resources.

Objective -- To provide a national data base of standardized sediment information for use in State, local, and Federal planning and action programs and to provide data for Federal management of interstate waters.

Approach -- A network of sediment stations has been established to provide spatial and temporal averages and trends of sediment concentration, discharge, and particle size being transported by rivers and streams.

Progress -- Water samples were collected on a routine basis at 131 stations during the 1980 water year for analysis and determination of suspended-sediment discharge. In addition, measurements were made of the particle-size distribution of suspended sediment and bed material. Figure 7 and table 4 (at the conclusion of this report) give the location of these sediment stations.

Plans -- Water samples are to be collected on a routine basis at 131 sites for analysis and determination of suspended-sediment discharge.

Reports published or released -- See numbers 31, 36, and 37 in "List of Reports... 
PROJECT TITLE: Automated water-use data base in Kansas

PROJECT NUMBER: KS-007

COOPERATING AGENCY: Division of Water Resources, Kansas State Board of Agriculture PROJECT CHIEF: C. H. Baker, Jr.

Problem -- Use of Kansas waters and competition among types of uses are increasing each year. State water-rights agencies need detailed information about water use in order to effectively manage the resource. As part of the National Water-Use program in Kansas, plans have been made to create a Stateoperated and maintained water-use/water-rights data base. This long-term plan has been pushed into the immediate foreground by a growing concern within the State for automated handling of water-use/water-rights data. In order to facilitate the progress of the water-use program in Kansas and to insure that the resulting State data base will fully meet the needs of the National Water-Use program, it is important for the U.S. Geological Survey to participate in the State data-base development.

Objective -- To design, implement, load, and evaluate an automated State water-use/water-rights data base. The data base will serve the dual functions of a management tool for administering water rights within the State and of acting as a repository for vital water-use data to meet National and State needs.

Approach -- Actual development of the data base will be done by the State Department of Administration, Division of Computer Services. Data capture, preparation, and input will be handled jointly by the Division of Water Resources, Kansas State Board of Agriculture, and the State Division of Computer Services. U.S. Geological Survey personnel will work closely with both State agencies to insure that all data elements needed for the National Water-Use program are provided in the data base and to provide for data exchange between the completed State data base and the National Water-Use Data System.

Progress --State personnel made excellent progress in the design and creation of water-rights/water-use data base on a State-owned computer. Programming is 80-percent complete, and data entry is about 40-percent complete. About 250 wells were visited by State and contractor personnel under the well-audit program to improve the quality of water-use data.

Plans -- The well-audit program will be continued, primarily with contractor personnel. Water-rights/water-use data base programming should be completed and the system fully operational by the second quarter of 1981 .

Reports published or released -- C. H. Baker presented an abstract of the National Water-Use Data Program before the 1979 spring meeting of the American Geophysical Union. Also see number 1 in "List of Reports...." 


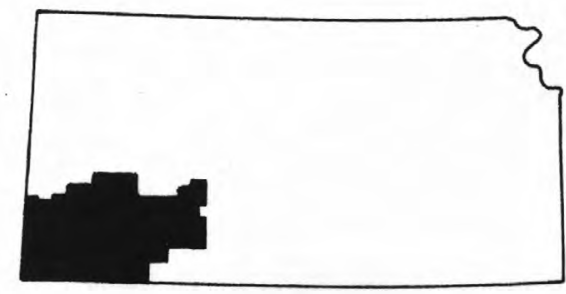

PROJECT TITLE: Hydrologic-data base for management decisions in Southwest Kansas Groundwater Management District No. 3

PROJECT NUMBER: KS-086

COOPERATING AGENCY: Southwest Kansas Groundwater Management District No. 3 PROJECT CHIEF: H. F. Grubb

Problem -- Management, planning, and administration of water rights depend on the avaiTability of and ready access to hydrologic data. State and local water agencies that must make these decisions have requested establishment of a system to provide current information on (1) large-yield wells in southwest Kansas, (2) the amount and time distribution of ground-water withdrawals, (3) the amount and location of irrigated acreage, (4) the hydraulic characteristics of the Ogallala aquifer, (5) the configuration of the water table, (6) the annual changes in saturated thickness, and (7) the movement of ground water through the aquifer system. Most of this data are readily amenable to storage, retrieval, and analysis using digital computers.

Objective -- To develop and maintain a comprehensive hydrologic-data base for the area within the Southwest Kansas Groundwater Management District and to provide timely storage, retrieval, and analyses of the data for use principally by the Management District and by the Division of Water Resources, Kansas State Board of Agriculture, in the management, planning, and administration of water rights.

Approach -- Establish and monitor a comprehensive observation-well network, complete and update an inventory of large-yield wells, perform several aquifer tests on selected wells, and assist the Management District in measuring and monitoring ground-water withdrawals for irrigation. Compile all data pertinent to the hydrology of the area in readily accessible computer files for various analyses essential to management and administrative decisions.

Progress -- The water available and the percentage of available water appropriated were calculated for northwestern Finney County based on the Groundwater Management District's depletion rules. A report is in preparation that describes a 9-square-mile radial-flow model and the use of interactive-computer files of water availability and water rights for identification of areas where managers can allow further development of ground water was completed.

Plans -- A saturated thickness map will be prepared for the Southwest Kansa s Groundwater Management District No. 3 from January 1981 water-level measurements. Kriging techniques and computer-based files of bedrock altitudes and water-table altitudes will be used to produce an error map and a machine-reproducable saturated thickness map. The completed report will be processed for publication. 


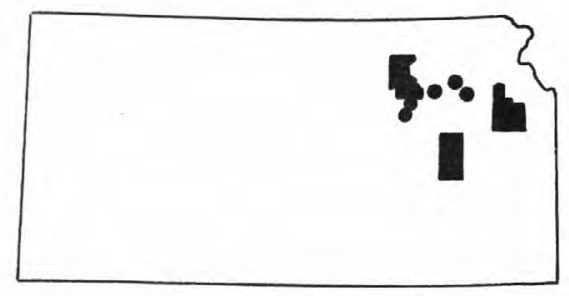

PROJECT TITLE: Flood-insurance studies for Federal Insurance Administration PROJECT NUMBER: KS-006

COOPERATING AGENCY: U.S. Department of Housing and Urban Development, Federal Insurance Administration

PROJECT CHIEF: K. D. Medina

Problem -- The National Flood Insurance Act of 1968 directs the Department of Housing and Urban Development to operate a flood-insurance program through the Federal Insurance Administration. Flood studies are needed in selected areas to determine applicable flood-insurance premium rates.

Objective -- Develop hydrologic and hydraulic data for actual and theoretical floods with 10-, 50-, 100- and 500-year recurrence intervals. Provide data to the Federal Insurance Administration for use in operating the floodinsurance program.

Approach-- Compute magnitudes and profiles of floods using ground surveys, photogrammetric methods, and computer models. Delineate, on planimetric base maps, areas that would be inundated by 100-year and 500-year floods.

Progress -- Intermediate meetings were held for Eudora, Manhattan, Ogden, Riley County, and Wichita, Kansas, and final meetings were held for Baldwin City, Douglas County, Lawrence, Perry, Rossville, Riley, St. Marys, and Wamego, Kansas.

Plans -- Complete review process, continue coordination with other agencies involved in flood-insrance studies, and participate in final meetings for remaining studies.

Reports published or released -- See numbers 30,33, 34, and 35 in "List of Reports..." 


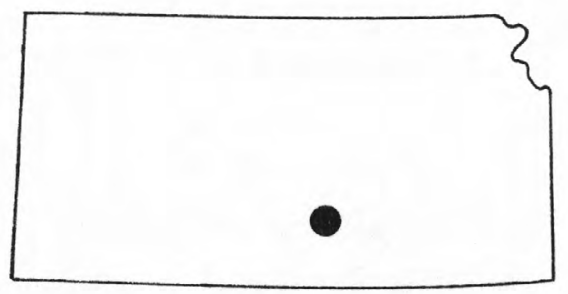

PROJECT TITLE: Effect of urbanization on flood runoff in the Wichita area PROJECT NUMBER: KS-013

COOPERATING AGENCY: City of Wichita, Kansas

PROJECT CHIEF: C. A. Perry

Problem -- The effects of urbanization on flood-frequency discharges in Kansas have not been quantified. Sprawling urbanization in Wichita and vicini$i$ ty has caused increased concern for the effect of urbanization on design discharges. Data on the magnitude and frequency of flood flows are needed in designing urban-drainage systems.

Objective -- Derive a method of estimating the relation of peak (flood) discharges to frequencies that is applicable to basins, with various degrees of urbanization, in the Wichita area.

Approach -- Collect rainfall-runoff data in basins where the 1 and use and percentage of impervious surface can be determined. Define the shape of unit hydrographs and changes resulting from urbanization. Test and calibrate a digital rainfal1-runoff model for predicting peak discharges from small urbanized basins.

Progress -- The report on evaluation of a method for determining the relation of peak discharge to rainfall was approved and published. Data collection continued for a more detailed study using a rainfall-runoff model.

Plans -- Continue collecting stage and rainfall data from small urban basins in wichita and prepare data for use in a rainfall-runoff model.

Reports published or released -- See number 27 in "List of Reports... ." 


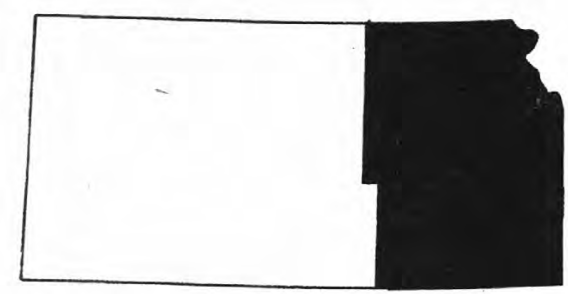

PROJECT TITLE: Water for municipal supply during severe droughts in eastern Kansas

PROJECT NUMBER: KS-058

COOPERATING AGENCY: Kansas Geological Survey

PROJECT CHIEF: H. G. O'Connor

Problem -- Municipal water supplies for many cities in eastern Kansas are obtained from wells, springs, or streams with yields that historically have been insufficient to meet the demand for water during extended periods of drought.

Objective -- Locate and evaluate the adequacy of all feasible sources of water in easternKansas that could be used for supplementing municipal supplies during periods of severe drought.

Approach -- Compile all available information from State and local water agencies to identify cities that have limited water supplies in relation to the population served, especially those cities that were critically short of water during the drought from the fall of 1951 to the spring of 1957 . Evaluate the availability of water from all feasible sources for use as a supplemental supply during droughts, including the emergency utilization of trucks, railroads, existing pipelines, or temporary piṕlines.

Progress -- All available information collected during the study, including 250 pages of tables and descriptive information for 43 counties in easternKansas, have been placed in the Kansas Geological Survey's open-file (informal publication).

Plans -- A summary of the report will be published by the Kansas Geological Survey in their Journal Series. The project was completed in FY 79. 


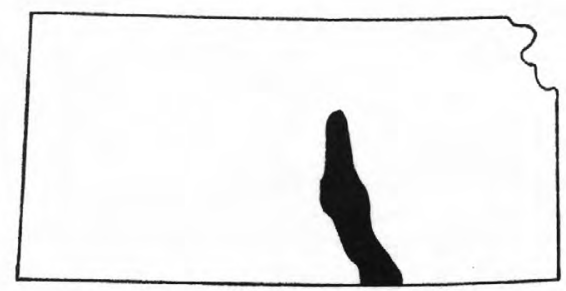

PROJECT TITLE: Discharge of saltwater from the Permian rocks to major streamaquifer systems in central and south-central Kansas

PROJECT NUMBER: KS-073

COOPERATING AGENCY: Kansas Geological Survey

PROJECT CHIEF : A. J. Goge1

Problem -- Degradation of freshwater aquifers and streams in central Kansas has occurred locally as a result of natural saline-water discharge from the Wellington Formation of Permian age. Although this occurrence is well known, little documented information is available on the cause, areal extent, and severity of degradation from saline-water movement. The chemical suitability of both ground and surface water for municipal, industrial, and irrigation supplies is adversely affected by the saline water in a large, heavily populated area of Kansas.

Objective -- Describe the general geohydrologic relation of the saline water in the Wellington Formation to the freshwater in the major unconsolidated aquifers in central Kansas; determine the location, extent, and severity of the natural saline-water discharge into the major stream-aquifer systems; and provide State and local water agencies with possible methods for alleviation or control of pollution.

Approach -- Compile all available data from previous reports and from files; drill test wells for geologic and hydrologic information; obtain waterlevel measurements from the different water-bearing formations; make seepagesalinity measurements in selected streams to detect changes in quantity and quality of flow; and collect ground-water samples for analysis to define the general operation of the geohydrologic system. Determine the probable source and movement of saline water from the Wellington to freshwater aquifers or streams. Construct and calibrate a digital model of the system for evaluating various schemes of alleviating or controlling pollution.

Progress -- The final report for this study has been approved for release to the U.S. Geological Survey Open-File, pending formal publication in the Kansas Geological Survey's Chemical Quality Series (see number 9 in "List of Reports Plans -- Project completed. Reports released or published -- See number 9 in "List of Reports...". 


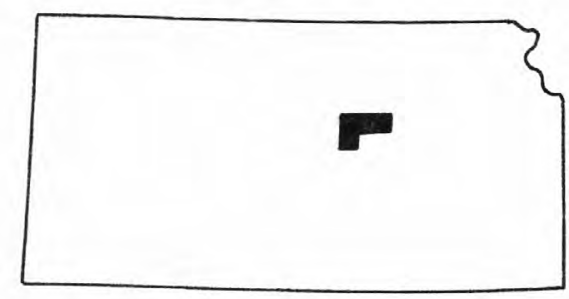

PROJECT TITLE: Saline discharge to the Smoky Hill River between Salina and PROJECT NUMBER: KS-074 Abilene, central Kansas

COOPERATING AGENCY: Kansas Water Resources Board PROJECT CHIEF: J. B. Gillespie

Problem -- The chemical quality of water in the Smoky Hill River is degraded by the natural inflow of saline water from Permian rocks. The saline inflow increases the concentration of chlorides to more than 250 milligrams per liter at downstream municipal and industrial intakes. Water from storage in reservoirs, which probably will be needed for water supply in the future, is currently being released to dilute the in-stream river flow.

Objective -- Determine the location and extent of saline-water inflow to the Smoky Hill River, the source and movement of saline water in the adjacent rocks, and possible methods of controlling or alleviating the pollution caused by the natural inflow of saline water.

Approach -- Collect data on existing wells and drill additional wells; make stage-discharge measurements of the Smoky Hill River; and collect groundwater and surface-water samples for analysis to determine the hydrologic and chemical relations of water in the Permian rocks, the alluvium, and the river. Construct and test a digital model of the existing river-aquifer system to check the conceptual model of the hydrologic system.

Progress -- The final report is in the last stages of technical review.

Plans -- Revise final report, following review, as necessary to improve accuracy and clarity. Submit report for Director's approval to publish as a Kansas Water Resources Board Bulletin. 


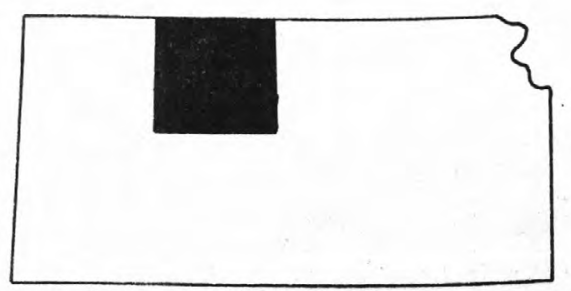

PROJECT TITLE: Water resources in north-central Kansas

PROJECT NUMBER: KS-075

COOPERATING AGENCY: Kansas Geological Survey

PROJECT CHIEF: L. E. Stullken

Problem -- Inflow to reservoirs from ground- and surface-water sources in north-central Kansas has been decreasing. The reservoirs were constructed to provide water for irrigation, municipal supplies, recreation, and waterquality control and to provide storage for flood control and the administration of water rights. The reduced availability of water in the reservoirs is adversely affecting downstream irrigation and is aggravating conflicts over water rights.

Objective -- Determine (1) the availability of ground water from principal aquifers in Norton, Phillips, Smith, Graham, Rooks, Osborne, Trego, Ellis, and Russell Counties; (2) the availability of surface-water runoff to major streams in the area; (3) the interrelationship between ground and surface water in the geohydrologic system; and (4) the effects of irrigation on the system.

Approach -- Compile information from existing high-yield wells and from drilled test wells to determine the character of the geohydrologic system and the areal extent and effects of ground-water development. Define the streamaquifer system in the major valleys and construct a digital model for use by State and local agencies in the management and planning for conjunctive use of the available ground-water and surface-water supplies.

Progress -- (1) Constructed, calibrated, and reported on steady-state models of two stream-aquifer systems--the North Fork Solomon River and Prairie Dog Creek; (2) compiled a hydrologic-data report of all high-yield wells and logs of all unpublished U.S. Geological Survey and Kansas Geological Survey test holes drilled in the nine-county area; and (3) determined that sufficient data are not available to calibrate a steady-state model of the South Fork Solomon River stream-aquifer system and subsequently advanced to the construction of a transient-state model.

Plans -- Calibrate the transient-flow model of the South Fork Solomon River valley and report on simulation. 


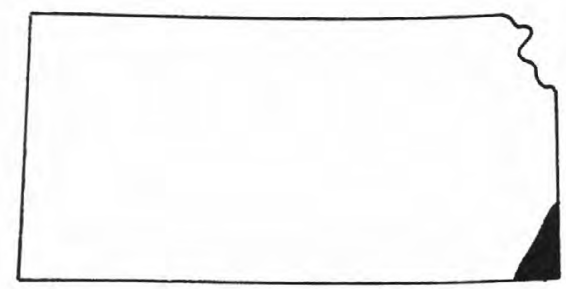

PROJECT TITLE: Quality of water in streams draining mined areas in southeast Kansas

PROJECT NUMBER: KS-076

COOPERATING AGENCY: Kansas Department of Health and Environment

PROJECT CHIEFS: A. M. Diaz and H. E. Bevans

Problem -- Information is needed to establish "benchmark" or baseline data on flow and current water-quality characteristics of streams draining areas in southeast Kansas that have been deep-shaft and strip mined for coal, lead, and zinc; to determine water-quality degradation associated with mining and with land-reclamation activities; and to evaluate the effects of State and Federal mining regulations on water-quality degradation in areas that may be mined in the future.

Objective -- Provide the data and interpretive evaluation needed to define the water-quality characteristics and the water, chemical, and sediment discharges of streams draining areas mined for coal, lead, and zinc. Determine the source, extent, type of chemical pollution, and effects of degradition on the quality of streamflow.

Approach-- Establish gaging stations on selected streams and collect baseline data on water discharge, chemical quality, and sediment discharge and determine the principal chemical and biological constituents, trace elements, and physical characteristics. Analyze samples to determine concentrations of nitrogen and phosphorus, total organic carbon, chemical oxygen demand, pesticides, and herbicides and to determine the concentration of suspended sediment and the particle size of suspended and bed material.

Progress -- Hydrologic-data collection at selected sites on Cow Creek and Cherry Creek was completed. The peak of record was measured on Cow Creek, November 22, 1980. Data analysis and interpretation continued. Two open-file reports were completed and published. A final interpretive report for the project is in preparation. The stations Cow Creek near Weir and Cherry Creek near Hollowell were selected for continued monitoring by inclusion in the statewide hydrologic-data network of streamflow stations.

Plans -- Complete interpretive report.

Reports published or released -- See numbers 3 and 4 in "List of Reports 


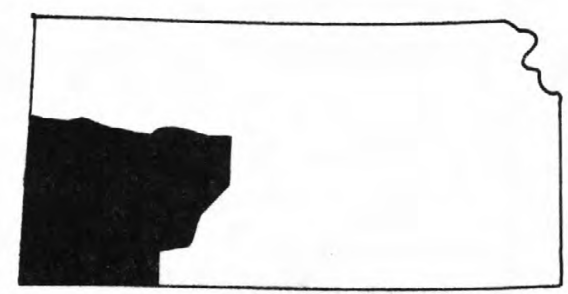

PROJECT TITLE: Availability and chemical quality of ground water from sandstone aquifers in southwest Kansas

PROJECT NUMBER: KS-079

COOPERATING AGENCY: Kansas Geological Survey

PROJECT CHIEF: Jack Kume

Problem -- A significant potential may exist for the development of groundwater supplies from sandstone units in Upper Permian, Upper Jurassic, and Lower Cretaceous rocks in southwest Kansas. Previous studies commonly considered the sandstone units as a single undifferentiated aquifer, which has lead to erroneous conclusions. Detailed studies are needed to define the geohydrology and the chemical quality of water in the sandstone-aquifer system.

Objective -- Define the character of geologic formations that compose the sands tone-aquifer system; determine the geohydrologic relations between the individual aquifers; describe the chemical quality and suitability of water for most uses; and predict possible effects of ground-water development on the availability and chemical quality of water resulting from induced leakage between sandstone units.

Approach -- Compile data from previous studies and from existing wells and drill additional test wells to define the geologic and hydrologic characteristics of the sandstone-aquifer system. Obtain more detailed information on the areal extent, thickness, and degree of cementation of individual sandstone units and on the effects of hydraulic interconnection between units.

Progress -- The field work has been completed. The hydrologic-data and final interpretive reports have been written and are in review.

Plans -- Drafts of the hydrologic-data report and the final interpretive report wiTl be reviewed and published. 


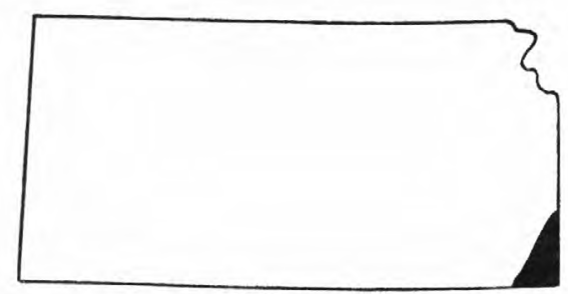

PROJECT TITLE: Effects of mining and land reclamation on hydrology of southeast Kansas

PROJECT NUMBER: KS-081

COOPERAITNG AGENCY: Kansas Geological Survey

PROJECT CHIEFS: A. M. Diaz, J. F. Kenny, J. R. Mccauley

Problem -- Effects of past and present mining of coal, lead, and zinc in southeastKansas have caused degradation of streams draining the mined areas. Quantitative measures of degradation and identification of source areas are needed to assess the effectiveness of pollution-control measures, the possible need for changes in mining and reclamation procedures, and the design of a longterm water-quality-monitoring network in southeast Kansas.

Objective -- Utilize the extensive water-quality data being collected in project KS-076 and remotely sensed data from aircraft and LANDSAT to (1) identify the point-source areas where poor-quality water discharges from old shaft mines, strip pits, collapsed areas, spoil embankments, and reclaimed areas; (2) evaluate the 1and-reclamation effects on water quality by analyzing areal and temporal changes in vegetative vigor in reclaimed areas; (3) establish a continuing monitor program, using computer-enhanced imagery, to detect anomolies associated with acid drainage; and (4) use results from this information to design an improved long-term water-quality-monitoring network for the mining areas in southeast Kansas.

Approach -- Remote-sensing techniques will be used to obtain data for analysis with signal-enhancement systems and digital densitometers to discriminate differences in water quality, degrees of vegetative vigor, and "hot spots" in mined areas versus degradation related to drainage from shaft mines, stripped areas, collapsed underground workings, and coal-processing activities. Additional ground-truth data will be collected in anomolous areas identified from the remotely sensed data. The data will be used to design a long-term waterquality-monitoring network.

Progress -- Analysis and interpretation of data from remote-sensing imagery continued. Maps of the coal-mined areas were prepared showing: (1) The extent of deep mining in the project area; (2) the extent of strip mining; (3) minedland inventory; and (4) the hydrology and extent of stream degradation. Geologic cross sections showing the relationship of the mined-out coal seams, streambeds, and point-source contamination were also prepared. An interpretative report for the study was completed. tion.

Plans -- Complete report review and obtainDirector's approval for publica- 


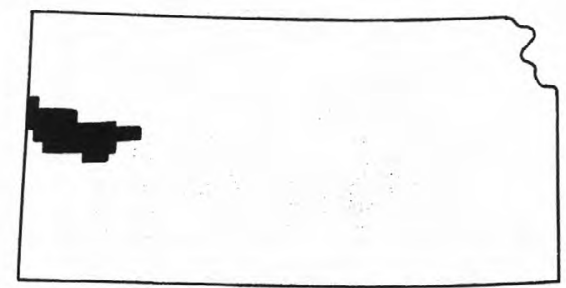

PROJECT TITLE: Geohydrology for water-supply planning in Groundwater Management District No. 1, west-central Kansas

PROJECT NUMBER: KS-082

COOPERATING AGENCY: Western Kansas Groundwater Management District No. 1 PROJECT CHIEF: Jack Kume

Problem -- Withdrawals of ground water for irrigation in west-central Kansas are depleting the amount of water stored in the unconsolidated deposits. Because the local irrigation-based economy is being adversely affected, the continued availability of ground water is of immediate concern to State and local water-planning and management agencies. Information is needed to determine the effects of various water-management alternatives to conserve ground water through efficient use.

Objective -- Compile and maintain a comprehensive hydrologic-data base; provide a detailed description of the geohydrologic system; and construct and calibrate a digital model of the system's operation. Apply models to "critical areas" designated by the Management District to analyze the effects of various management strategies for improving irrigation efficiency and for optimal development of ground water.

Approach -- Establish a comprehensive ground-water data base and prepare geohydrologic studies of "critical areas" designated by the Management District. One study will establish a project area that demonstrates the conservation of water and energy through improved irrigation efficiency. Other studies will utilize digital models to test effects of management alternatives on irrigation efficiency and on the conservation of ground water.

Progress -- The field work and data collection have been completed. An observation well in the Ogallala aquifer was installed at a recharge site near Modoc. A stream-gaging station and low-flow control were al so constructed near this site. A hydrologic-data report has been published (see number 13 in "List of Reports..."). The final interpretive report have been written and is in review. A short report showing simulated water-level declines near Marienthal, west-central Kansas has been written, reviewed, and published (see number 8 in "List of Report...").

Plans -- Continue monitoring the water-levels in observation wells at the Modoc recharge site, adjacent to the tailwater pit, and along Ladder Creek, and monitor the amount of rainfall and runoff at the gaging station near Modoc. Complete the review process on the final interpretive report and publish.

Reports published or released -- See numbers 8 and 13 in "List of Reports 


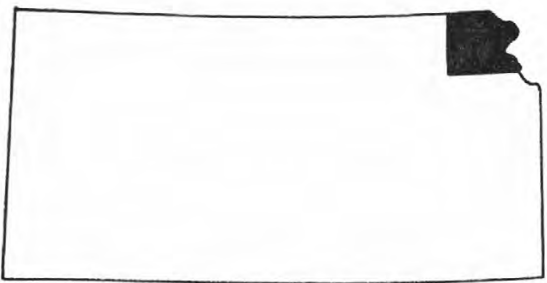

PROJECT TITLE: Fluvial sediment and water quality in selected SCS watersheds of northeast Kansas

PROJECT NUMBER: KS-083

COOPERATING AGENCY: Soil Conservation Service

PROJECT CHIEF : A. M. DIaZ

Problem -- A practical definition is needed for sediment-transport conditions from small drainage areas in Kansas. The Soil Conservation Service (SCS) is especially interested in the environmental impact of land-treatment practices on sediment yield and the chemical quality of water in areas with flow-way structures. Data are required to define a base for conditions necessary to maintain water quality within design limits for use as guidelines in future watershed developments.

Objective -- Provide chemical- and sediment-discharge parameters in relation to water discharge at 12 selected sites in northeastern Kansas; define the relation of streamflow parameters to sediment concentrations and particle sizes; and investigate the general relation of chemical quality of water to streamflow and to sediment characteristics.

Approach -- Install equipment at 12 measurement sites, including singlestage sediment samplers and wire-weight gages. Four sites also will have creststage gages for recording maximum flow elevations. One site will be equipped with an electrically operated single-stage sampler, a peak-stage recorder, and a chemical-quality monitor for evaluation. Observers will collect sediment samples during rainfall-runoff periods, and hydrographers will make measurements to define relations of streamflow to gage heights, sediment concentrations, and chemical quality.

Progress -- Suspended-sediment and chemical-quality samples were collected as scheduled in fiscal year 1979. Chemical analyses of water, sediment, and bed material show no indication of toxic constituents for expected uses. Selected analyses of bacteria indicated high fecal coliform count during rainfall-runoff events. Four sites on Pony Creek near Sabetha were equipped with crest-stage and single-stage sediment samplers. Chemical quality with pesticide and biological samples were collected at the Pony Creek sites.

In fiscal year 1980, statistical summaries of fluvial-sediment data were prepared. Synthetic flow-duration curves were developed for the study area. An analysis of a covariance test indicated that suspended-sediment loads per unit discharge have not changed as a result of Soil Conservation Service sediment-control structures in the project area. Channel cross-sections were resurveyed to determine the effects of SCS sediment-control structures on channel stability. Collection of suspended-sediment and chemical-quality samples continued but was hampered by drought conditions and a relative shortage of runoff events.

Plans -- Publish interpretive report. 


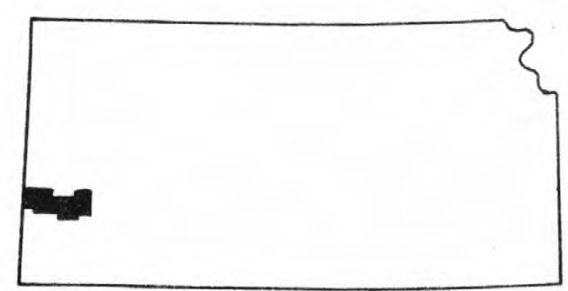

PROJECT TITLE: Geohydrology of the Arkansas River valley in southwest Kansas PROJECT NUMBER: KS-088

COOPERATING AGENCY: Division of Water Resources, Kansas State Board of Agriculture PROJECT CHIEF: R. A. Barker

Problem -- Flow of the Arkansas River between the Colorado-Kansas State line and the Kearny-Finney County line in Kansas has continued to decrease in recent years. Consequently, the availability of surface water for diversion at the headgates of irrigation ditches has been inadequate to meet demands. Withdrawals of ground water from wells in the valley alluvium, which is hydraulically connected to the stream, are thought to be depleting streamflow and adversely affecting senior water rights.

Objective -- Define the relationship between ground water and surface water in the Arkansas River valley and determine the effects of ground-water withdrawals on streamflow. Construct and calibrate a digital model of the river-aquifer system that can be used by State and local management agencies to improve conjunctive use of ground and surface waters within the constraints of the waterrights structure in Kansas.

Approach -- Determine the hydrologic boundaries of the stream-aquifer system, the hydrautic characteristics of the aquifer, the hydrologic stresses imposed on the system, and the effects of those stresses on ground-water storage and on streamflow. These data will be used in a digital model of the system to predict the results of various management alternatives designed to optimize conjunctive use of ground and surface waters.

Progress -- Calibration was partially completed on a finite-element model to simulate the interaction between the Arkansas River and the adjacent alluvial aquifer. Depletion of ground and surface waters in the project area during the 1970 's was found to have resulted most significantly from (1) decreased streamflow delivery from Colorado, (2) increased ground-water pumpage, and (3) the combination of decreased precipitation and increased evapotranspiration caused by the drought of the early and middle 1970's. State-line streamflow decreased from an average 168,000 acre-feet per year during 1951-69 to an average annual rate of 60,000 acre-feet between 1970-78. Pumpage increased from about 20,000 acre-feet during 1970 to nearly 60,000 acre-feet during 1978. Precipitation between 1970-78 averaged 15 percent less than the 85-year average at Syracuse.

Plans -- Use calibrated model to analyze the response of the modeled system to possible future conditions of stress, and complete report describing the geohydrology and computer simulation of the project area. 


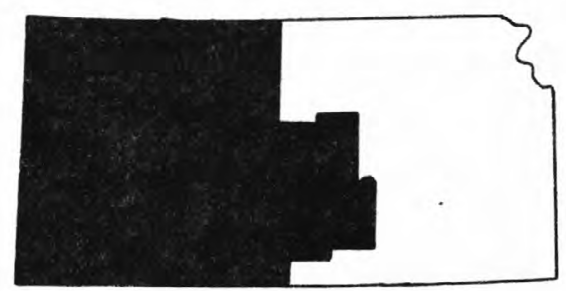

PROJECT TITLE: Techniques for estimating ground-water withdrawals in western Kansas

PROJECT NUMBER: KS-090

COOPERATING AGENCY: Kansas Water Resources Board

PROJECT CHIEF: C. H. Baker, Jr.

Problem -- One of the principal unknown factors in quantitative groundwater hydroTogy and management of ground-water resources is the quantity of water withdrawn for irrigation use. The measurement of ground-water pumpage by installation of totalizing flow meters is possible but very expensive.

Objective -- Investigate methods, other than metering of wells, for determining the withdrawal of ground water from irrigation wells in Kansas with an acceptable degree of accuracy and test such methods by application to a large irrigated area.

Approach -- The project is divided into two parts: Part 1 will be to 1 ist, describe, and evaluate different methods of obtaining discharges at a well site and for an area; Part 2 will be to field test any suitable method(s) evaluated in Part 1 on a large irrigated area, such as a ground-water management district.

Progress -- An interim report was completed and approved for publication. During the 1979 irrigation season, about 80 wells in Scott County, Kansas, were equipped with running-time sentry units. These wells were monitored for running time and discharge rate to obtain good records of the total amount of water pumped for irrigation for specific crops. Data collection and analyses continued through the 1980 irrigation season.

Plans -- Complete final report.

Reports published or released -- See number 2 in "List of Reports...." 


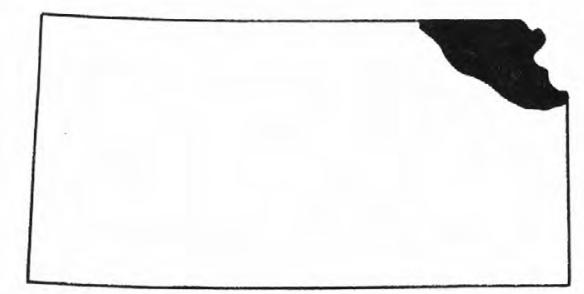

PROJECT TITLE: Glacial deposits (Pleistocene) in northeast Kansas

PROJECT NUMBER: KS-091

COOPERATING AGENCY: Kansas Geological Survey

PROJECT CHIEF: J. E. Denne

Problem -- As population and demand for water increase in northeast Kansas, ground-water supplies are gaining in significance. They are especially important during periods of low precipitation when surface-water supplies decline. Although the bedrock formations in the area generally contain little, if any, good-quality water, the glacial buried-valley aquifers may yield up to several hundred gallons per minute of freshwater to wells.

Because the buried-valley aquifers are variable in location, extent, and hydrologic characteristics, detailed study of them is necessary. Current aquifer usage and development potential for domestic, municipal, agricultural, and industrial needs also must be evaluated. These analyses will allow realistic water-resource planning for the area. Knowledge of aquifer locations also should allow protection of ground water from contamination.

The geophysical techniques (for example, seismic, resistivity, and thermal) developed and utilized in this program should prove useful for studies of other unconsolidated aquifers in Kansas.

Objective -- The objectives of this study are to: (1) Locate and delineate the major Pleistocene aquifers of northeast Kansas, (2) determine ground-water levels in and saturated thicknesses of these aquifers, (3) analyze the Pleistocene stratigraphy and the character of the glacial deposits, (4) analyze the quality of waters contained in the Pleistocene aquifers, (5) determine current municipal, agricultural, and industrial usage of the aquifers, and (6) evaluate future potential of the aquifers for water supplies.

Approach -- Buried-valley aquifers will be located by evaluation of existing hydrogeologic information, interpretation of maps and remote-sensing data, and field work (drilling and geophysical investigations). Ground-water levels will be measured in wells and test holes, and saturated thicknesses will be calculated. Grain size and clay mineralogy of sediments will be analyzed for stratigraphic correlation and aquifer evaluation. Chemical constituents of water from Pleistocene aquifers will be determined by sample analyses (performed by the Kansas Department of Health and Environment). 
Progress -- Geologic and ground-water information for the 16-county study area has been collected and assembled from published and unpublished sources. We11 logs have been obtained from drillers and engineering firms, the Kansas Department of Transportation, the Missouri Division of Geology and Land Survey, and other sources. Approximately 1,000 water-well records and other well logs have been field checked for location and surface elevation. Additional data have been obtained by auger and rotary test drilling in Nemaha, Leavenworth, Jefferson, Atchison, Brown, Washington, and Johnson Counties. More than 150 test holes have been drilled. Thicknesses of unconsolidated deposits, elevation of bedrock and water levels have been plotted on 1:62,500-scale county maps. Data for several counties have been entered into a computer file.

Geophysical techniques (including seismic and resistivity) have been used to obtain additional information regarding bedrock depths, character of unconsolidated deposits, and water levels. Shallow earth temperatures have been measured over known and suspected buried valleys in Jefferson County. Positive (warm) anomalies in winter and negative (cool) anomalies in summer have been found over the aquifers.

Thermal and LANDSAT imagery, mosaics of conventional aerial photographs, and topographic maps are being evaluated to determine whether glacial buried valleys have characteristic surface expressions. Some field investigations are being done in areas with tonal or topographic features that could correspond to buried valleys.

Sediment samples have been collected from test holes for laboratory analyses and evaluation of the hydrologic character of the aquifers. Municipal, industrial, and irrigation water-use data for northeast Kansas were obtained from the Division of Water Resources, Kansas State Board of Agriculture.

Water-quality data available from the U.S. Geological Survey were obtained and evaluated. Maps and charts showing certain water-quality parameters, well depths, and aquifers were prepared for Nemaha, Brown, and eastern Marshall Counties. Additional sites for water-quality sampling in buried valleys have been selected from water-well records.

Plans -- Continue drilling and geophysical investigations. Collect waterquality samples from buried valleys and inventory water levels. Begin computer mapping of data and continue ongoing program elements.

Reports published or released -- See number 7 in "List of Reports... ." 


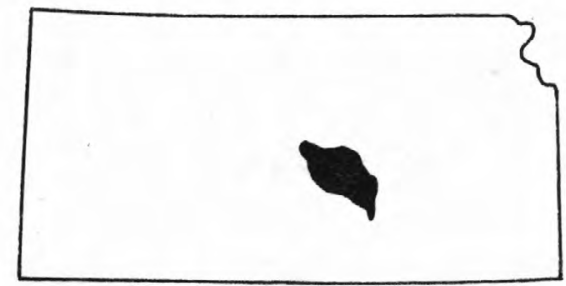

PROJECT TITLE: Hydrogeology of the "Equus beds" aquifer, central Kansas

PROJECT NUMBER: KS-092

COOPERATING AGENCY: Kansas Geological Survey

PROJECT CHIEF: J. B. Gillespie

Problem -- Unconsolidated deposits of Pleistocene age, commonly known as the "Equus beds," are the major source of water for municipal, industrial, and irrigation use in central Kansas. Continued increasing withdrawals of water from this important aquifer will result in mining of water, reduced well yields, deterioration of water quality, and impairment of existing water rights.

Objective -- Determine the effects that increased ground-water withdrawals will have on (1) ground-water availability and (2) chemical quality of the ground water as they relate to the possible contamination of parts of the "Equus beds" as a result of induced movement of saline water now present in the aquifer and saline-water inflow from the underlying Wellington aquifer.

Approach -- Additional data will be collected with special emphasis on defining the chloride distribution in the aquifer and on modeling of the groundwater flow system. An appropriate model will be selected that will simulate the movement of saline water. Evaluation of the simulation will be made, and new model development may result.

Progress -- A seepage run was made during low-flow conditions on the Little Arkansas River. All municipal pumpage data have been collected, compiled, and entered into the automatic-data-processing system. A bedrock map has been completed. Aqui fer tests have been reanalyzed, and a transmissivity map is essentially complete. Two observation wells were completed at each of two sites, with wells screened immediately above bedrock and about 40 feet bel ow the water table. Six auger holes were drilled and completed as observation wells. Water-quality samples and pumpage data were collected from the observation wells.

Plans -- Construct and calibrate a ground-water flow model and a solutetransport model of the "Equus beds" area. Write the final report. 


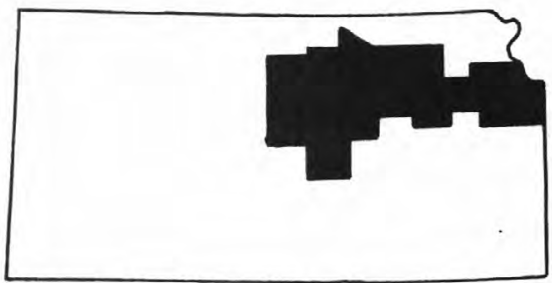

PROJECT TITLE: Channel-geometry investigations for the Kansas River Bank Stabilization Study

PROJECT NUMBER: KS-095

COOPERATING AGENCY: U.S. Department of Army, Corps of Engineers

PROJECT CHIEF : W. R. Osterkamp

Problem -- The U.S. Army Corps of Engineers, Kansas City, has undertaken a comprehensive bank-stabilization study of the Kansas River and some of its major tributaries. The study was initiated to identify possible causes of various types of recent channel instability, including widening, scouring, and lateral shifting. The influence of discharge regulation and interruption of sediment supply by major reservoirs in the basin are to be investigated. Integral parts of the study include investigations of channel-geometry and sediment-discharge characteristics. Both investigations should provide pertinent information for the interpretive phase of the bank-stabilization study.

Objective -- Identify relative degrees of chemical instability in the downstream direction and determine why current channel changes are occurring. Identify significant alterations in sediment size and supply to the lower part of the basin that have occurred in the last few decades and, if possible, relate the alterations to trends in land-use practices and to construction of major reservoirs.

Approach--Channel-geometry width, channel-gradient, and particle-size data will be collected in the Kansas River basin below major reservoirs. The data will be analyzed by computer to obtain relations between discharge and other variables currently typical for the basin and to determine downstream changes in the relations. Deviations of data sets from previously determined relations will be used to interpret the possible instability of a reach. All pertinent sediment data for the area will be compiled and analyzed for sucessive changes in sediment concentrations and discharge; similar analyses will be made for the sizes of suspended and bed sediment.

Progress --Fieldmeasurements, sample collection, and compilation of sediment data are complete. Initial maps showing areal variation of sediment yields in the Kansas River basin were constructed. Computer analyses of channel-geometry data and final interpretations of areal variations in sediment yields were made.

Plans -- A final report is being prepared. 


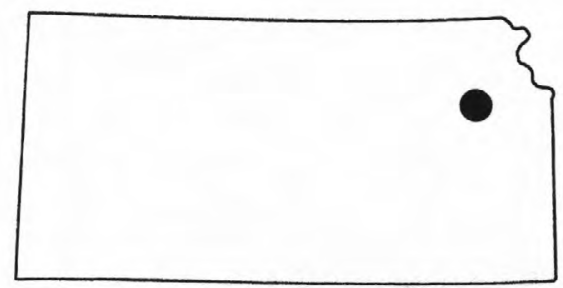

PROJECT TITLE: Quality of water from urban runoff, Topeka PROJECT NUMBER: KS-096 COOPERATING AGENCY: Kansas Department of Health and Environment PROJECT CHIEFS: A. M. Diaz and L. M. Pope

Problem -- The Kansas Department of Health and Environment must obtain information to evaluate the impact of urbanization on the water resources of the State. Some Kansas counties are heavily urbanized, others currently are being urbanized, and still others are planned for urban development. One of the major urban developments in Kansas is in Shawnee County. Urbanization has seriously affected the hydrology of Shawnee County. A critical need exists for data relating to characteristics of urban runoff in the county, primarily with respect to the quality of water from runoff in the City of Topeka.

Objective -- Establish a data base from selected study areas within the City of Topeka that will include streamflow, physiographic, climatic, and waterquality information. Evaluate the quality of water by defining the physical, chemical, and biological characteristics of runoff from selected urban areas under existing conditions andmake projections of these characteristics of runoff that may occur with future urban development.

Approach -- Streamflow, physiographic, climatic, and water-quality data will be collected at selected sites, which will be equipped with stream-gaging and water-quality monitoring equipment. Data will be collected to determine the variation of water quality within storm events and among seasons. Peak chemical concentrations and total chemical loads will be identified. Water-quality parameters will consist of chemical inorganics, trace metals, nutrients, organics, biological, bacteriological, and sediment.

Progress -- Collection of baseline and runoff data continued. Shelters to house automatic sample-collection equipment, water-quality monitors, and recording rain gages were installed at five of the continuous-recording streamflow sites.

Plans -- Complete the installation of sampling and monitoring equipment, continuedata collection, and prepare progress report. Select two small basins (one urbanized, one undeveloped) for later instrumentation and model application. 


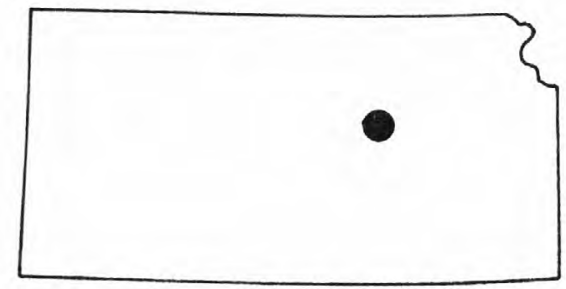

PROJECT TITLE: Hydrologic properties of the Wellington aquifer near Salina PROJECT NUMBER: KS-098

COOPERATING AGENCY: U.S. Department of Army, Corps of Engineers

PROJECT CHIEF: J. B. Gillespie

Problem -- The U.S. Army Corps of Engineers is undertaking a water-management study of the Kansas River basin. As part of the study, the Corps is interested in the saline ground-water discharge into the Smoky Hill River near Salina. The source of the sal ine water entering the Smoky Hill River is the Wellington aquifer, which mainly underlies the alluvium of the Smoky Hill Valley in this area. No measured values of the hydrologic properties are available for the Wellington aquifer near Salina. Such data are needed to determine more accurately brine distribution and movement in this area.

Objective -- Determine the transmissivity and storage coefficient of the brine-filled Wellington aquifer northeast of Salina and obtain hydrogeologic data on the gypsum-cavity distribution and limits of the brine flow in the Wellington aquifer in the study area.

Approach -- Production wells, with observation wells at appropriate distances, will be installed. The well casings will be cemented to prevent contamination of the overlying alluvial aquifer. Brine produced from the wells will be disposed of by storage in surface tanks and tank trucks, if the well discharge is small, or piped one-half mile and injected back into the Wellington aquifer, if the well discharge would be too large for surface storage. Aquifer tests will be conducted, and the results analyzed using the latest analytical methods available.

Progress -- Four test wells were drilled and installed in the Wellington aquifer. Data were obtained from two aquifer tests by pumping from one well at 21.2 gallons per minute into a pipeline and injecting the pumped brine into a well 2,600 feet away. Observation wells were placed 50 feet away from each of the test wells.

Plans -- Plans are to complete data analysis and interpretation. This was a one-year project begun in FY 79 and was combined with project number KS-110 for fiscal year 1980 . 


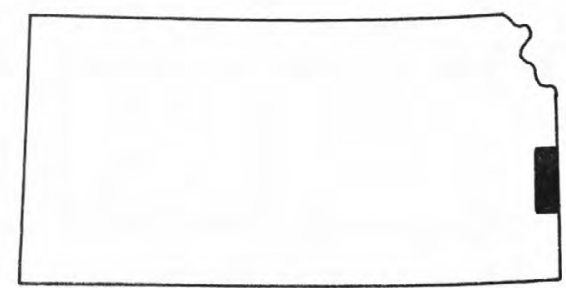

PROJECT TITLE: Effects of strip mining on the hydrology and water quality in Linn, Miami, and Bourbon Counties

PROJECT NUMBER: KS-099

COOPERATING AGENCY: U.S. Department of the Interior, Office of Surface Mining Reclamation and Enforcement

PROJECT CHIEF: H. E. Bevans

Problem -- Strippable reserves of the Mulberry Coal in Linn, Miami, and Bourbon Counties in east-central Kansas are estimated to be between 40-50 million tons. Because of the projected demand for coal, it is expected that extensive mining will probably begin in Kansas by about 1980-81. The major stream drainages traversing the three-county area are those of the Marais des Cygnes, the Little 0sage, and the Marmaton Rivers. The thickness of the strippable coal is generally less than 4 feet; hence, the ratio of 1 and-surface area disturbed to tonnage of coal mined will probabiy be one of the highest in the industry. The regional impact on hydrology must be evaluated by pre- and post-mining assessment.

Objective -- Determine the available hydrologic and related data for the study area and provide the interpretation and supportive data needed to describe the hydrologic environment. Determine future data and studies necessary for evaluating the impact of strip mining on the water-quality characteristics (physical, chemical, and biological) of the ground- and surface-water systems. Finally, model predictive changes in the quality of water in the hydrologic system during and after mining of an area.

Approach -- Hydrologic information will be obtained from a systematic threephase project. Phase I will be directed toward the compilation of maps describing the physical setting and hydrology of the study area. Phase I interpretive results will be used in phase II to determine (1) site selection, (2) hydrologicdata needs, (3) site-specific data needs, and (4) frequency of sample collection. In phase III, predictive model(s) will be developed to determine the impact of strip mining on the hydrology of the study area. Ideally the model(s) would be developed for a selected subbasin with a drainage area of 15 square miles or less. The model(s) would have utility in the planning of future strip-mining activities.

Progress -- Data-collection sites were selected, and sampling frequencies and laboratory schedules were finalized. Scheduled data-collection activities were initiated. Continuous-recording streamflow gages were installed at three sites on North Sugar Creek. Work continued on a preliminary report describing the physical setting of the project area.

Plans -- Continue the collection of hydrologic data. Begin data analysis and interpretation and preparation of final report. 


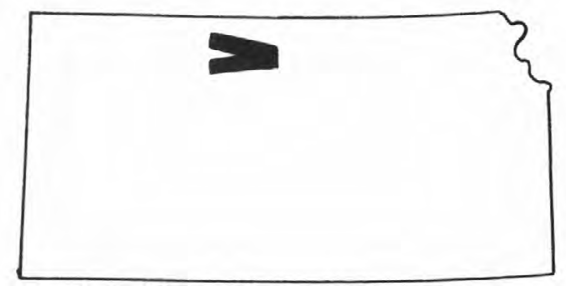

PROJECT TITLE: Conjunctive-use models for North and South Fork Solomon Rivers, north-central Kansas

PROJECT NUMBER: KS-100

COOPERATING AGENCY: U.S. Department of the Interior, Water and Power Resources Service

PROJECT CHIEF : R. D. Burnett

Problem -- The management of surface water and ground water, which are used for irrigation in the Solomon River valleys, is becoming more critical. Deficiencies in recent years of surface water for irrigation have resulted in the increasing use of ground water to supplement the available surface water. The conjunctive use of surface and ground waters will be required for optimal use of the water resources of the valleys. The streams and alluvial aquifers are in close hydraulic connection and should be studied as a stream-aquifer system.

Objective -- Model the stream-aquifer systems in the valleys of the North and South Fork of the Solomon River above Waconda Lake and below Kirwin and Webster Dams and evaluate various management alternatives for the stream-aquifer systems utilizing the digital model.

Approach -- A digital model of each stream-aquifer system will be utilized. The models will be capable of "inputting" streamflow, surface-water irrigation, pumping, and recharge data on a monthly basis. Various water allocations both of surface water and ground water will be tested as management al ternatives, and a prediction as to the response of the stream-aquifer system will be made. The model of the valley of the South Fork Solomon River is to be studied in phase 1. The modeling of the valley of the North Fork Solomon River will be considered in phase 2 .

Progress -- A transient numerical model has been developed for the South Fork Solomon Basin between Webster Reservoir and Waconda Lake, and predictive simulations of management alternatives have been completed. A transient finiteelement model has been completed on the North Fork Solomon River.

Plans -- Predictive simulations of management al ternatives will be completed, and reports will be written on both the North Fork and South Fork Solomon River valleys. 


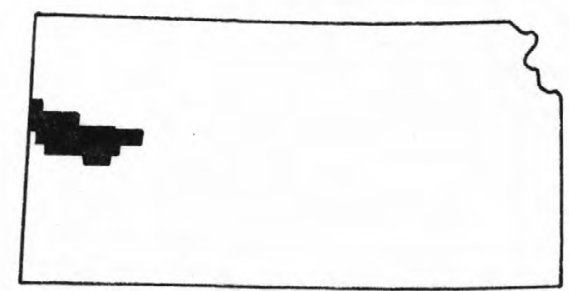

PROJECT TITLE: Ground-water depletion maps, west-central Kansas PROJECT NUMBER: KS-105

COOPERATING AGENCY: Western Kansas Groundwater Management District No. 1 PROJECT CHIEF: Lloyd E. Dunlap

Problem -- The ground water in west-central Kansas is being mined primarily for irrigation. The Western Kansas Groundwater Management District No. 1 has developed a management plan for this area based on the percentage depletion of the ground-water resources since 1950. The management District needs, on an annual basis, a map that will accurately represent the state of ground-water depletion and that will be relatively free from the effects of local anomalies.

Objective -- (1) Investigate methods of transforming contour maps to digital form, (2) identify digitizing methods that will preserve the hydrogeologic interpretations of the various maps and provide consistent digital information on a square-mile basis, (3) select a reproducible methodology for preparing maps of saturated thickness and percentage change in saturated thickness, and (4) prepare maps of 3-year average saturated thickness and percentage change in saturated thickness since 1950 for Western Kansas Groundwater Management District No. 1.

Approach -- Simple polynomial interpolation, trend surface analysis, and other regionalization techniques, such as kriging, will be used to obtain estimates of bedrock elevation and 1978 water levels for each square mile of the Groundwater Management District using available point data. The utility of the different methods will be evaluated by preparing a 1978 saturated thickness map of the study area and by making comparisons with the map previously prepared by the point data and the bedrock/water-level contour intersection method.

Progress -- The technique of kriging was used to estimate the 1978-80 water-table surface at unmeasured sites in the management district. Bedrock and 1950 water-table surfaces were estimated also for the centers of mile sections in the district. From this data, maps and plots of the 1978-80 water-table surface, saturated thickness, and percentage change of saturated thickness were produced for the management district.

Plans -- Write an interpretive report and construct a map report. 


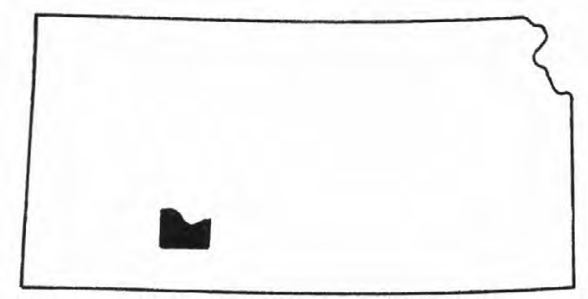

PROJECT TITLE: Water resources of Ford County

PROJECT NUMBER: KS-106

COOPERATING AGENCY: Southwest Kansas Groundwater Management District No. 3

PROJECT CHIEF: Joseph Spinazola

Problem -- The rate of depletion of the water resources in Ford County has accelerated in recent years. Increased ground-water pumpage and coincident drought conditions have caused declines in water levels. Water levels in the unconsolidated aquifer have declined 7 to 10 feet since 1940 . Industrial and agricultural demand for water continues to be strong, and available data are not adequate for local water managers to allocate the diminishing water supply in an equitable and hydrologically sound fashion.

Objective -- (1) Update the hydrologic data base for the county, including an estimate of water use from the unconsolidated aquifers, (2) document the areal aquifer response to pumping stresses, and (3) determine the availability of water, for irrigation or other uses, as defined by the guidelines of the Southwest Kansas Groundwater Management District No. 3.

Approach -- The hydrologic data base will be updated by an inventory of large-capacity wells in the county and by measurement of the discharge of about 8 percent of the wells. Total ground-water withdrawal will be estimated by an evapotranspiration model, which utilizes a soil-moisture accounting procedure. The aquifer's areal response to pumping will be shown by a water-table map constructed during the pumping season. Availability of water for large-capacity wells will be determined by using the water-table map and the 9-square-mile depletion model recently developed by the U.S. Geological Survey for a project in west-central Kansas (KS-082).

Progress -- Inventory of approximately 750 irrigation wells is 98 percent complete. Driller's logs were assembled from the Kansas Geological Survey. Discharge was measured from 25 irrigation wells.

Plans -- Assemble crop-acreage data for crop years 1980 and $1981 . \quad$ Construct bedrock, saturated thickness, and water-level maps, and enter data report into District review. 


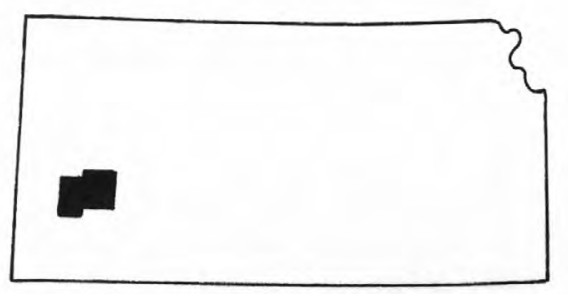

PROJECT TITLE: Effects of ground-water withdrawals on water levels and streamflow in the Arkansas River near Garden City

PROJECT NUMBER: KS-107

COOPERATING AGENCY: Division of Water Resources, Kansas State Board of Agriculture

PROJECT CHIEF: Lloyd E. Dunlap

Problem -- The flow of the Arkansas River at Garden City has diminished during the Tast decade such that the frequency of flow has decreased from about 90 to 10 percent. Concurrently, large-scale irrigation has developed in the sand hills south of the river from the Bear Creek Fault in Kearny County to the vicinity of Garden City. Consequently, the yields of old irrigation wells near the river have decreased, and the rate of water-level declines has accelerated. Recent requests for appropriation of large quantities of ground water for industrial use in this area may adversely affect senior water rights.

Objective -- Define the relationships among the Arkansas River, the valley alluvial aquifer, and the underlying unconsolidated aquifer of the Ogallala Formation; determine the changes in the relationship between the ground-water system and the Arkansas River; and construct; test, and apply a digital groundwater flow model to determine the effects of pumping ground water from the unconsolidated Ogallala aquifer south of the Arkansas River on flow of the river, on the yield of wells in the valley alluvial aquifer, and on water-level declines north of the river.

Approach -- Principal work items in this project will be to determine: The hydrologic boundaries of the stream-aquifer system, (2) the hydraulic characteristics of the aquifers, (3) the hydrologic stresses that are being imposed on the system, and (4) the effects of the hydrologic stresses on the streamaquifer system. These data will be used in a multilayer digital ground-water flow model of the system to evaluate the effects of various management alternatives on the availability of ground water and on flow of the Arkansas River.

Progress -- Streamflow, water-level, and climatic data were collected and compiled. A well inventory of the project area was completed, and 12 observation wells were drilled in the alluvium. Horizontal and vertical boundaries of the aquifer indicate that it is a multilayer system.

Plans -- Continue to collect and compile hydrologic data in the project area. Collect pumpage data by means of a soil-zone model. Calibrate a threedimensional, finite-difference model of the area and then make projections for the future. 


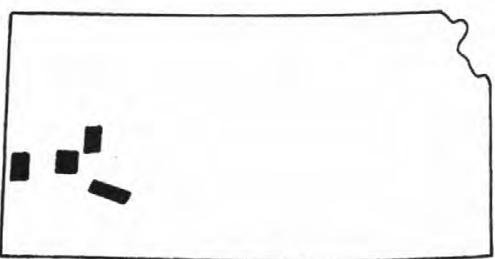

PROJECT TITLE: Geohydrology and water quality of deep-aquifer systems, Cretaceous and Jurassic ages, western Kansas

PROJECT NUMBER: KS-109

COOPERATING AGENCY: Kansas Department of Health and Environment

PROJECT CHIEF : Jack Kume

Problem -- The High Plains aquifer system has been stressed extensively in much of western Kansas. The underlying rocks of Cretaceous and Jurassic ages contain permeable units that have potential for use as alternative sources of water supply. The permeable zones within these rocks are used for disposal of brine that is produced with oil and gas from the underlying rocks. A real hazzard exists for contamination of the Cretaceous-Jurassic aquifer system if brine disposal continues without a sound hydrologic basis.

Objective -- Define the geohydrology of the rocks of Cretaceous and Jurassic ages in detail at selected sites. Determine the vertical and horizontal variation in chemical quality of water in the permeable zones and determine the head differences between permeable zones and across confining beds. Determine the hydraulic characteristics of principal permeable zones and regionalize the results using available geophysical logs and other oil-and gas-exploration data.

Approach -- Use lithologic and geophysical logs of oil and gas test wells to determine test-drilling sites. A test-drilling program will provide detailed geohydrologic data needed to define the hydrology of the aquifers and the confining beds in the rocks of Cretaceous and Jurassic ages. Arrangements will be made to use selected unsuccessful oil and gas test holes before they are plugged or to re-enter plugged test holes. Special well-completion and packer tests will be used, as applicable, to permit the independent measurements of heads in permeable zones, the testing of hydraulic characteristics, and the obtaining of ground-water samples.

Progress -- Geophysical logs from $0 i 1$ and gas tests have been studied for correlation of formations and site selection of dry and abandoned oil wells. Water samples have been collected from seven stock, domestic, and industrial wells in the lower Cretaceous aquifers.

Plans -- Six abandoned oilfield wells are to be converted into freshwater observation wells. Water sampling will continue. 


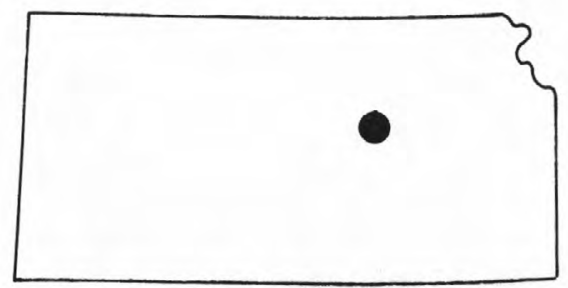

PROJECT TITLE: Geohydrology of the Wellington Formation and Smoky Hill Valley alluvium in the Salina area, central Kansas

PROJECT NUMBER: KS-110

COOPERATING AGENCY: Kansas Water Resources Board

PROJECT CHIEF: J. B. Gillespie

Problem -- Saline water is discharged from the alluvial aquifer into the Smoky Hill and Solomon Rivers east of Salina. The source of the saline water is brine from the underlying Wellington aquifer. The eastward movement of brine in the Wellington aquifer is believed to be confined to a limited cross section under the alluvium of the Smoky Hill Valley. A tight confining shale layer exists between the two aquifers northeast of Salina. The most promising method for alleviation of saline-water contamination of the aquifer-stream system may be the construction of a line of relief wells in the Wellington aquifer extending across the Smoky Hill River valley in the area northeast of Salina. The brine discharged from the relief wells could possibly be injected into deep saline aquifers.

Objective -- Define more accurately the area under which the brine is flowing eastward in the Wellington aquifer. Determine the volume of brine moving eastward and delineate any areas of saline-water contamination in the alluvial aquifer in the Salina area. Determine location of relief wells to intercept eastward-flowing brine and predict the effects of different pumping alternatives on brine $f l$ ow by using a digital model.

Approach -- Test holes will be drilled on the north and south sides of the valley boundaries to determine if there is any brine following underneath the adjacent uplands. Also, additional wells will be installed in the Wellington aquifer underlying the valley alluvium. Aquifer tests will be conducted on these wells, and the brine will be injected into the deep Arbuckle aquifer. Short- and long-term aquifer tests will be conducted on both aquifers simultaneously. Observation wells will be augered in the alluvium. Water samples from both the Wellington and alluvial aquifers will be collected for chemical analysis. A quasi-three-dimensional digital model will be constructed to predict the effects of different pumping on brine flow.

Progress -- Conducted one aquifer test on a well in the Wellington aquifer drilled by the U.S. Army Corps of Engineers in 1979. The preliminary results indicate a transmissivity of about 1,500 feet squared per day. The chloride concentration was 145,000 milligrams per liter.

Plans -- Conduct a long-term aquifer test (1 month) on a Wellington aquifer well in the center of the Smoky Hill Valley and dispose of the brine in an Arbuckle well about 400 feet away. Test drilling and augering will be conducted also. 
STA TEWIDE

PROJECT TITLE: Flood investigations - Department of Transportation

PROJECT NUMBER: KS-010

COOPERATING AGENCY: Kansas Department of Transportation

PROJECT CHIEF: R. W. Clement

Problem-- There is a continuing need for adequately defined flood-frequency characteristics for Kansas streams to assist in the efficient design of highway drainage structures, for flood-plain analysis, and to evaluate flood-risk factors. Long-term records of annual peak discharges are necessary to adequately define flood-frequency characteristics. Al though streamflow records have been collected on Kansas streams since 1895, they are limited primarily to those streams that drain areas larger than 100 square miles. Very little long-term data are available for streams draining areas of less than 100 square miles.

Objective -- Define the flood-frequency characteristics on gaged streams in Kansas using long-term data, both observed and synthesized, and extend those characteristics to ungaged locations.

Approach -- Records of annual peak discharges on small drainage areas are obtained from a crest-stage gage network. Selected crest-stage gage sites are equipped to collect simultaneous records of continuous rainfall and discharge. Long-term records of annual peak discharges are synthesized through the use of a rainfall-runoff model and a record of long-term rainfall. Data for large drainage areas are available from the regular stream-gaging network. Floodfrequency relations, determined by statistical methods, are extended to ungaged sites by using physical and climatic factors.

Progress -- Peak-flow data were collected and published for 60 crest-stage gage stations, including 10 rainfall-runoff sites. Long-term synthesis was completed using rainfall-runoff models for 13 previously operated sites and 3 long-term rainfall records. Prepared draft of report on results of rainfallrunoff models in eastern Kansas.

Plans -- Operation of 60 crest-stage gages, including 10 rainfall-runoff sites, wiTl be continued. Continue compiling data from 10 currently operating rainfal1-runoff stations. Begin preparation of data for updating flood-frequency characteristics on Kansas streams. New data will include results of long-term synthesis of rainfall-runoff models. Prepare bridge-site reports upon request from cooperator.

Reports... 
ST A TEWIDE

PROJECT TITLE: Streamflow characteristics

PROJECT NUMBER: KS-011

COOPERATING AGENCY: Kansas Water Resources Board

PROJECT CHIEF: P. R. Jordan

Problem -- There is a need to express basic streamflow records in more usefut forms and to develop improved methods of estimating the frequency of various types of flow in gaged and ungaged streams in Kansas.

Objective-- Define the significant characteristics of streamflow in Kansas; determine the interrelation between streamflow and ground-water storage; analyze and summarize existing data in useful terms for developing optimum benefit from the available water supplies and optimum protection from floods.

Approach -- Analyze significant streamflow characteristics and update results of previous studies using improved methods applied to initial data and additional data from 16 to 20 years of records, particularly that data from small drainage basins. Where available, improved analytical techniques will be used to determine flow probabilities.

Progress -- The statistical summary of streamflow characteristics for the Missouri River basin in Kansas was completed and transmitted to the cooperator for publication. Fulfilled numerous requests for hydrologic data, including a summary of surface-water data on western Kansas streams for use in the High Plains Economic Study. Analyzed low-flow data and began preparation of report on low-flow frequency.

Plans -- Complete report on low-flow frequency (statewide) and begin analysis of high-flow-volume data. Fulfill requests for hydrologic data from the cooperator and the public.

Reports published or released -- See number 12 in "List of Reports... ." 


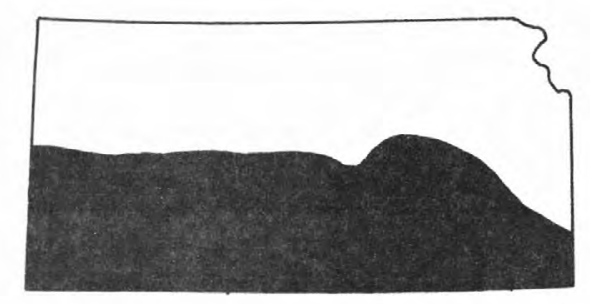

PROJECT TITLE: Duties for the Kansas-0klahoma Arkansas River Commission PROJECT NUMBER: KS-041

COOPERATING AGENCY: Kansas-0k1ahoma Arkansas River Commission

PROJECT CHIEF : E. R. Hedman

Problem -- The Kansas-0klahoma Arkansas River Commission is composed of representatives of the States of Kansas and 0klahoma. The administration of the compact requires that certain water data be compiled and presented to the Commission.

Objective -- Compilation of water data needed for the administration of the Arkansas River compact and performance of duties as Secretary-Treasurer for the Commission.

Approach -- Water data needed are collected as part of existing programs, and data are compiled, as required, and are presented to the Commission. Duties of Secretary-Treasurer for the Commission are performed by the project chief.

Progress -- Data were compiled as needed, and the Twelfth Annual Report-FiscaT Year 1979 was transmi tted to the Kansas-0k 1 ahoma Arkansas River Commission.

Plans -- Continue compilation of data as needed and supply information to the Commission. Continue performance of required duties as Secretary-Treasurer of the Commission. 
PROJECT TITLE: Special short-term hydrologic investigations and public inquiries PROJECT NUMBER: KS-045 COOPERATING AGENCY: Kansas Geological Survey PROJECT CHIEF: H. G. O'Connor

Problem -- Cooperating State agencies frequently request short-duration studies of specific high-priority problems that cannot be accommodated readily in ongoing projects. Information commonly is needed in areas other than those where projects currently are in progress, and an analysis of the problem may require special techniques or expertise generally not available from the requesting agency's staff.

Objective -- Provide a flexible means for programming short-duration, highpriority studies done at the special request of cooperating State agencies and provide a means of supplying geohydrologic information for specific requests by other Federal, State, and local agencies and by the general public.

Approach -- Collect, analyze, and interpret data for short-duration studies as required by cooperating State agencies and provide geohydrologic data requested by Federal, State, and local agencies and by the general public.

Progress -- Responded to more than 500 public inquiries and continued to assist the Governor's Task Force on Water Resources in fiscal year 1979. In fiscal year 1980, responded to more than 800 public inquiries.

Plans -- Continue to provide geohydrologic information as requested by cooperating State agencies and provide information requested by Federal, State, and local agencies and by the general public. 
PROJECT TITLE: Numerical models of streamflow PROJECT NUMBER: KS-059

COOPERATING AGENCY: Kansas Water Resources Board

PROJECT CHIEF: P. R. Jordan

Problem -- Currently available numerical models give reasonably satisfactory estimates of medium and high flows in Kansas, but modifications are needed to improve estimates of low flows. Because the rainfall-runoff relations of some streams apparently have changed in recent years, modifications of numerical models also are needed to aid in the revision of plans and operating procedures for some water-development projects.

Objective -- Develop modifications to improve the capability of numerical models for determining flow in Kansas streams (particularly low flow), the magnitude of changes in rainfall-runoff relations in some streams, and the future runoff expectancy under changed conditions.

Approach -- Examine possible improvements in modeling techniques by using data from drainage basins with different characteristics and by applying physical principles and empirical data on soil moisture, evapotranspiration, and groundwater recharge and discharge. Use modified numerical models to determine changes in rainfall-runoff relations and to calculate future runoff magnitude and probabilities for selected streams.

Progress -- Analyses of streamflow and rainfall data for changes in rainfall-runoff relations have been completed for four streams in western Kansas. Significant changes to smaller amounts of streamflow were found for three of the streams. Final adjustments were made to the rainfall-runoff model.

Plans -- The final report will be completed. 
PROJECT TITLE: Flood-hazard mapping

PROJECT NUMBER: KS-062

COOPERATING AGENCY: Federal

PROJECT CHIEF: C. A. Perry

Problem -- The U.S. Geological Survey has been assigned the responsibility of providing flood-hazard information according to a national program outlined by U.S. House of Representative Document 465. Areas that would be inundated by a 100-year flood are delineated on U.S. Geological Survey 7 1/2-minute topographic maps.

Objective -- Determine the extent of areas that would be inundated by a 100-year flood based on data from existing flood-frequency studies and other available data and delineate those areas on topographic maps.

Approach -- Prepare maps of flood-prone areas using available data from gaging stations and relationships between flood depths, flood discharges, frequency of occurrence, and drainage area to define flood profiles and flood boundaries.

14 maps.

Progress -- Prepared 41 flood-prone area maps, and reviewed and published

Plans -- Review, complete, and transmit 31 flood-prone maps that have been partialty prepared.

Reports published or released -- Flood-prone area maps for the St. John North, St. John South, Alton, HarTan, Portis, Downs North, Downs South, Bloomington, Osborne, Dorrance SW, Holyrood NE, Black Wolf, Wilson, and Dorrance quadrangles were released during FY 80. 
PROJECT TITLE: Evaluation of the Ground-Water-Quality Monitoring Network PROJECT NUMBER: KS-077

COOPERATING AGENCY: Kansas Department of Health and Environment

PROJECT CHIEFS: A. M. Diaz and T. B. Spruil1

Problem -- Data on the chemical quality of ground water is needed from a statewide network of wells in response to State and Federal regulations imposed by the Safe Drinking Water Act of 1975 (Public Law 93-523). A continuing evaluation of the adequacy of the network is needed for monitoring the groundwater quality in the principal aquifers of the State.

Objective -- Evaluate the chemical-quality data to determine the adequacy of the network for describing baseline ground-water quality, for detecting pollution of the principal aquifers in the State, and for determining the significance of the data in respect to State and Federal water-quality standards imposed by the Safe Drinking Water Act.

Approach -- Collect water samples for chemical analysis from a statewide network of about 500 wells. The wells will be sampled to provide baseline data for determining the general chemical quality of ground water in the principal aquifers and to facilitate early detection of pollution in the area of existing drinking-water supplies. Interpretation of sampled data will continue, and the adequacy of data will be reanalyzed for detecting changes in chemical quality and in local occurrence of pollution.

Progress -- Sampling of network wells was continued. A preliminary draft of a reportpresenting all available chemical data from network wells and classification and assessment of regional ground-water quality in Kansas is being prepared. Data evaluation indicates that analyses of annually obtained groundwater samples are inadequate to assess long-term trends in ground-water quality. Reports on this topic and on the occurrance of nitrate-nitrogen are also in preparation.

Plans -- Continue sampling of established network wells and selection of additional wells to be added to the network where coverage is lacking. Continue entry of chemical data from WATSTØRE to the Ground-Water-Station Inventory File, and field verification of locations of wells within the Kansas network. Complete reports and evaluation of data and network design. 
PROJECT TITLE: Potential for liquid-waste injection into the Arbuckle Group PROJECT NUMBER: KS-078

COOPERATING AGENCY: Kansas Geological Survey

PROJECT CHIEF: A. J. Gogel

Problem -- Rocks of the Arbuckle Group, which underlie nearly all of Kansas, are important oil reservoirs in much of the State and are an important freshwater aquifer in the southeastern part. The rocks also are a primary horizon for waste disposal, particularly oilfield brine. Little is known about the regional geohydrology and the potential effects of contamination to freshwater aquifers.

Objective -- Determine the regional geohydrology of the Arbuckle Group from available data and further define the Arbuckle Group by making a prel iminary assessment of the potential for waste injection to the aquifer. Determine the hydraulic parameters and potential for liquid-waste injection at site-specific areas.

Approach -- Compile data to determine the areal extent and thickness of aquifers, the areal changes in hydraulic and chemical characteristics, and the configuration of the potentiometric surface of saline water in the Arbuckle and other aquifers. Observation wells will be installed at selected sites to monitor changes in head and chemical quality. Modeling techniques will be used to evaluate the potential for future injection and storage of liquid wastes and to assess the effects of waste injection on freshwater aquifers.

Progress -- All drill-stem test data have been analyzed for transmissivity, hydraulic conductivity, and freshwater-equivalent potentiometric surface. Potentiometric maps of six geologic horizons have been completed. Four deep observation wells were completed in the Arbuckle in Douglas, Miami, Labette, and Saline Counties. These wells were tested at various horizons for hydraulic information, and water-quality samples were collected from the Arbuckle.

Plans -- Consider the effects of variable water density on flow direction. Injection tests will be conducted at two of the drilling sites. Data gained from these tests will be used to construct digital ground-water flow models at each site. This will allow preliminary determination of acceptability of site(s) for liquid-waste disposal. 


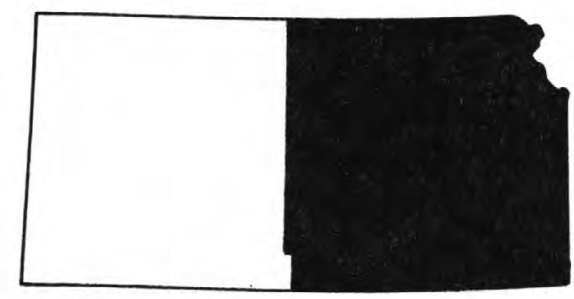

PROJECT TITLE: Aquifer-test evaluation

PROJECT NUMBERS: KS-093

COOPERATING AGENCY: Kansas Geological Survey

PROJECT CHIEF : R. D. Burnett

Problem -- Current aquifer appraisal projects in eastern Kansas require more accurate values for hydraulic characteristics than those available from previous studies. The files of the U.S. Geological Survey, the Kansas Geological Survey, and the Division of Water Resources of the Kansas State Board of Agriculture contain data from numerous aquifer tests, which have been conducted since 1937. These tests need to be reanalyzed to provide a cohesive set of reliable aquifer parameters that may be used as the basic building blocks for quantitative evaluations.

Objective -- To create an accurate reproducible documented file of aquifer parameters by aquifer and by area for use in current areal investigations and investigations that are being considered for the future.

Approach -- Compile all available data from aquifer tests in eastern Kansas; evaluate tests for adequacy of documentation; and collect supplemental data from other sources for interpretation. Determine the appropriate analytical or numerical techniques for application to the aquifer tests, and collate aquifertest results in a useful summary form.

Progress -- Pumping test data for approximately 60 aquifer tests scattered over the project area have been collected. About 40 pumping tests have been analyzed using methods developed by Jacob, Hantush, and Boulton. Preliminary work on the final report has begun.

Plans -- Continue aquifer-test analyses and finish report. 


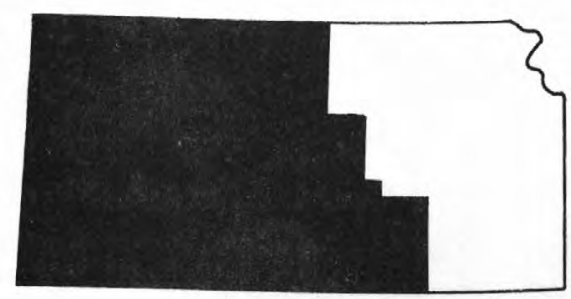

PROJECT TITLE: High Plains regional aquifer-system analysis, western Kansas PROJECT NUMBER: KS-094

COOPERATING AGENCY: Federal

PROJECT CHIEF: L. E. Stullken

Problem -- The Ogallala Formation is the principal aquifer underlying the High Plains. The aquifer contains about 2 billion acre-feet of water in storage, but water is being withdrawn for irrigation in excess of the rate of natural replenishment. The economic future of the High Plains in eight states, including Kansas, is dependent upon the capacity of the aquifer to sustain withdrawals. A detailed knowledge of the aquifer system is needed so that the system can be simulated, water-management alternatives evaluated, and the economic life of the aquifer projected.

Objective -- Previous studies of the hydrology of the High Plains have been limited by political boundaries. This study will provide a regional description of the water resources and the operation of the hydrologic system consistent with the natural hydrologic boundaries of the High Plains. Computer models of the aquifer system will be developed and used to project the future response of the system to proposed future withdrawals and provide a basis for the economic evaluation of water-management alternatives.

Approach -- Existing hydrologic data will be compiled and reviewed. Data collection networks will be revised or initiated to provide adequate coverage for the study area. The data will be regionalized to provide a detailed description of the aquifer system and stored in a digital computer for processing and retrieval. The computerized datafile will provide the data base needed for the development of computer models of the aquifer system. Proposed water-management alternatives and their effects on the aquifer system will be simulated by the models to evaluate the economic life of the system for each management al ternative.

Progress -- Measured irrigation-well discharges and time-of-operation at 90 randomly selected sites in the High Plains tri-state water-use test area. Compiled a map report on the "Generalized configuration of the base of the High Plains regional aquifer system in Kansas." Mapped type of irrigation and irrigated crops in Cheyenne and Sherman Counties, Kansas, and completed an analysis of base flows from the 0gallala aquifer. Mapped 1975,1970, 1965, 1960, and predevelopment water levels in High Plains aquifer; mapped specific yield and hydraulic conductivity in the High Plains aquifer; calculated the pumpage from the High Plains aquifer; and initiated digital modeling of the High Plains aquifer system in two dimensions--in western Kansas by U.S. Geological Survey staff and in south-central Kansas by contract with the Kansas Geological Survey.

Plans -- Continue steady-state modeling effort and reconsider the adequacy of currently available data and time in terms of developing transient-state ground-water models for evaluation of water-management alternatives. 
PROJECT TITLE: Central Midwest Regional Analysis

PROJECT NUMBER: KS-111

COOPERATING AGENCY: Federal

PROJECT CHIEF: C. H. Baker, Jr.

Problem -- The hydrology of the deeper freshwater, brackish-water, and saline-water aquifer systems in rocks of Cambrian-Ordovician to Cretaceous ages is not well defined. Because of the increased demand on the overlying High Plains aquifer system in western Kansas, aquifers in this deeper rock system are being looked upon as a potential source of additional water supply. In addition, increased demand in eastern Kansas has caused saline-water encroachment into aquifers of this rock system. Added to these problems are those resulting from injection of industrial wastes and oilfield brine into these rocks.

Objective -- Describe the hydrology of the freshwater, brackish-water, and saline-water aquifer systems in rock of Cambrian-Ordovician to Cretaceous ages. Create a regional data base for the rock systems and describe present and potential problems associated with current and future water use. Evaluate the aquifer-system response to future stresses.

Approach -- A search of the available literature will be made to determine the extent of geologic-framework interpretations and available data. Data collection will follow literature search to establish a data base of regional significance that will include detailed lithologic descriptions for selected wells, water-quality information, hydraulic characteristics of the rock systems, and information on water use, waste disposal, and brine injection. Appropriate maps will be prepared, and a steady-state digital model constructed to test the conceptual-flow system and to define additional data needs to calibrate a digital model capable of simulating the flow system for predictive purposes.

Progress -- New project.

Plans -- Prepare detailed work plan and assemble staff. Review literature and compile and review existing data. 
PROJECT TITLE: Influence of sediment and other variables on active-channel

PROJECT NUMBER: KS

COOPERATING AGENCY: Federal

PROJECT CHIEF : W. R. Osterkamp

Problem -- Recent methods for estimating streamflow characteristics from channel-geometry data commonly result in large standard errors in width-discharge regressions. Current studies indicate that the regressions are strongly influenced by sediment and other variables, but insufficient data are available for adequate refinement. Information on the effects of particle size on channel shape and stability are needed to evaluate changes in response to 1 and use and hydraulic structures.

Objective -- Determine the influence of sediment on the channel geometry of alTuvial streams and the manner in which the silt-clay content of bed and bank material affects width-discharge regressions. Define the quantitative influence of sediment on channel-geometry methods to improve estimates of discharge from ungaged streams.

Approach -- Collect data on active-channel geometry at established gages in the Missouri River basin, collect bed and bank samples for size analyses, and correlate channel geometry to discharge and to silt-clay content in bed and bank material. Develop equations to express the effect of sediment on the channel-geometry relation within large ranges of climate and topography.

Progress -- Data were analyzed by digital computer, and the resulting power-function equations described the manner in which width-discharge relations of alluvial channels vary with the sediment characteristics.

Plans -- Project has been completed.

Reports published or released -- See number 17 in "List of Reports....." 
PROJECT TITLE: Channel geometry as related to discharge characteristics of regulated Kansas streams

PROJECT NUMBER: KS-087

COOPERATING AGENCY: Kansas Water Resources Board

PROJECT CHIEF : W. R. Osterkamp

Problem -- Differences in discharge variability are known to have a significant effect on the channel geometry of streams with similar mean discharge. Although previous studies have related channel width and depth to mean discharge and to flood-frequency discharges, little consideration has been given to the effect of discharge variability on channel shape. The increasing regulation by reservoirs has caused many streams in Kansas to have low flood discharges relative to mean discharge. The relation of channel geometry to flow characteristics in regulated streams is poorly defined.

Objective -- Define the relation of channel geometry to various parameters of discharge, specifically for regulated streams; determine the downstream changes in channel shape that occur on regulated streams; determine the changes in channel shape, gradient, sinuosity, and elevation as a result of reservoir regulation; and define the influence that sediment transport exerts on the geometry of regulated streams.

Approach -- Collect channel-geometry data and particle-size data of bed and bank material at established gaging stations and at sites between stations on regulated stream reaches. Utilize computer techniques of simple- and multipleregression analyses to relate various discharge characteristics determined from gaging-station records. Analyze the results of rating-curve shifts for specific gaging stations and the measurable changes in channel sinuosity and gradient that have occurred during regulated periods.

Progress -- Data collection and computer analyses of the data have been completed. Results suggest that reservoirs affect channel-geometry partly by reducing flood peaks and partly by limiting the proportion of total sediment discharge that can be moved as bedload.

Plans -- The final report will be submitted for colleague review.

Reports published or released -- See numbers 18, 19, and 22 in "List of Reports.... 
PROJECT TITLE: Water-yield estimation for small ungaged basins in Kansas PROJECT NUMBER: KS-089

COOPERATING AGENCY: Kansas Water Resources Board

PROJECT CHIEF: W. J. Carswell, Jr.

Problem -- Many communities and other water users, which are dependent on streamflow, experienced shortages during the drought of 1976-77 in Kansas and recognize the need to expand water supplies. An adequate method for estimating yields and carry-over storage requirements from streams draining less than 100 square miles is not available. Existing methods for estimating water yields from drainage basins exceeding 100 square miles in size previously have not been tested for smaller areas because of the lack of sufficient streamflow data for small streams in Kansas.

Objective -- Test the applicability and limitations of applying existing methods for estimating water yields and carry-over storage requirements for basins larger than 100 square miles to smaller basins. If existing methods are not applicable, develop new methods of estimating water yield and carryover storage requirements for ungaged basins with drainage areas smaller than 100 square miles.

Approach -- Water yields and carry-over storage requirements shown by existing low-flow data on small basins will be compared to values calculated by techniques available for ungaged basins larger than 100 square miles to test the applicability of the techniques to smaller basins. If existing techniques are found to be inadequate, new techniques will be developed for estimating water yields and carry-over storage requirements for ungaged small basins. Approaches to be examined will include nonlinear extension of the 1 arge-area methods, use of statistically regionalized flow parameters, and selection of an existing streamflow model for adaptation.

Progress -- Completed reports on multiyear low flow of streams in southeast and northeast Kansas. Storage requirements have been calculated for small gaged basins in Kansas. Using these results, a technique is being developed to estimate carry-over storage requirements for ungaged basins.

Plans -- The study will be completed and findings published as a U.S. Geological Survey Water-Resources Investigations in fiscal year 1981.

Reports published or released -- See numbers 5 and 6 in "List of Reports 
PROJECT TITLE: Streamflow characteristics related to channel geometry of streams in coal-lease areas

PROJECT NUMBER: KS-097

COOPERATING AGENCY: Federal

PROJECT CHIEF : E. R. Hedman

Problem -- Estimates of streamflow characteristics are presently required for hydrologic studies and assessment of the impact of coal mining in the central and western United States. In the regions where it is difficult to relate the streamflow characteristics to precipitation, drainage area, and other basin characteristics, additional methods are needed. Channel geometry is one such method. Streamflow characteristics have been related to channel geometry of streams in much of the western United States through many individual studies, mostly state wide. Results have been good for most perennial streams. These relations probably can be transferred to other areas, but some verification in each area will be necessary to assure this.

Objective -- The principal objectives of the study will be directed specifically to the strippable-coal areas in the central and western United States and are: (1) To verify the transferability of the existing relations of streamflow characteristics to measurable dimensions of channel geometry and channel material of perennial streams; (2) to devel op new relations of streamflow characteristics to measurable dimensions of channel geometry and channel material of ephemeral streams; and (3) to investigate the feasibility of estimating sedimenttransport characteristics for perennial and ephemeral streams.

Approach -- Channel-geometry data should be collected at gaging stations with 20 or more years of record on perennial streams, in or near the major coal areas, to verify existing relations. Existing relations could then be used directly or with adjustments if necessary. Channel-geometry data sufficient to develop statistically significant regression equations would be collected from suitable ephemeral sites throughout the western United States. Measurements should be made of the dimensions of channel geometry that have proved successful in other studies; for example, width and average depth of the channel cross section between in-channel depositional bars, the active channel, and the bankfull stage. Data collection should include sampling and particle-size analyses of bed and bank material.

Progress -- Data have been collected at 142 recording streamflow-gagingstation sites, of which 100 were ephemeral and the remainder were perennial and intermittent. Bed and bank material samples have been analyzed, and all data have been entered in a computer file.

Plans -- Additional data will be collected at gaging sites in California, New Mexico, and $0 \mathrm{klahoma.} \mathrm{All} \mathrm{data} \mathrm{will} \mathrm{be} \mathrm{related} \mathrm{to} \mathrm{streamflow} \mathrm{characteristics.}$ Complete final report.

Reports published or released -- See number 21 in "List of Reports...." 
PROJECT TITLE: Planning study for regional investigation of precipitation volume and intensity, its variability and possible fluctuation over a period of record

PROJECT NUMBER: KS-101

COOPERATING AGENCY: Federal

PROJECT CHIEF : C. A. Perry

Problem -- Precipitation is an important parameter in most hydrologic investigations, including studies of the hydrology of coal-mining areas. If precipitation is subject to time trends or cycles, the conclusions of many hydrologic studies would have questionable validity. Several studies have confirmed the absence of trends or cycles in long records of precipitation at a specific site. However, recent studies have indicated the possibility of cycles in the average precipitation over large areas. An investigation is needed to determine the presence or absence of cycles in average precipitation over the size of areas important for hydrologic studies.

Objective -- Conceptualize a regional investigation of areal precipitation volume and intensity to determine precipitation variability and possible trends or cycles over a long period of time. Assemble a data base from existing data and determine a plan of study for a regional investigation. Include possible effects of trends or cycles in precipitation data on other hydrologic studies.

Approach -- Conduct a literature search for best methods for study of time trends or cycles in precipitation data. Acquire precipitation data, as well as other supportive meteorological data, in a form that is compatible for high-speed computer usage. Prepare and publish a plan of study for a definitive investigation of trends or cycles in areal precipitation.

Progress -- The project began in May 1979 with data acquisition and a 1 iterrature search. Data on annual precipitation for eight regions, annual sunspot numbers, and number of sudden geomagnetic-storm commencements were analyzed. The correlation among regional precipitation, sunspot numbers, and sudden geomagneticstorm commencements was studied. The project's concepts and objectives were coordinated with the National Center for Atmospheric Research. A report on the preliminary analysis and plan of study was written.

Plans -- Report is to be published. Project ended at close of FY 79. 
PROJECT TITLE: Distribution information systems

PROJECT NUMBER: KS-102

COOPERATING AGENCY: Federal

PROJECT CHIEF: J. M. MCNellis

Problem-- The increasing demand for information concerning water resources, coupled with personnel ceilings, has worked to prevent timely assessment and distribution of water data. Technology transfer in the area of computer applications is slow to almost nonexistent, particularly for the final users of computer data.

Objective -- Demonstrate the feasibility of putting computer power in the hands of individual users and develop a plan for acquisition of minicomputers in the Water Resources Division of the U.S. Geological Survey.

Approach - - A Harris minicomputer has been installed in the Kansas District, and $i t$ is one of only three in the entire Water Resources Division. The others are located in New Mexico and in Reston, Virginia. The Kansas District will implement ground-water flow models, automatic rating analysis, and numerous other applications. Coordination and exchange of software among Kansas, New Mexico, and Reston will be maintained. In addition to the testing, coordination, and exchange, the results and experience of having minicomputer systems in the hands of users will be used in writing a request for purchase of other minicomputers for other locations in the Water Resources Division.

Progress -- A number of programs that are used extensively are running on the Harris minicomputer. Functional applications include administrative, basic data, publication, laboratory, computer, and hydrologic-investigation areas. The minicomputer is accessible to all Kansas District office personnel and is used directly by more than 50 percent and indirectly by all. Coordination and exchange of software among Kansas, New Mexico, and Reston are continuing.

Plans -- Development of programs for the minicomputer, with coordination and exchange among the three sites, will continue. Program developments include plotter, digitizer, and graphics capabilities. Information on minicomputers will be given to all Districts in the Water Resources Division, and the Districts will be polled as to their minicomputer requirements. Results of the poll will be used with the experience gained at the three demonstration sites in developing a request for purchase that will be written and sent to minicomputer vendors.

Reports published or released -- See number 15 in "List of Reports... ." 
1. Baker, C. H., Jr., 1979a, New instrumentation for the National Water-Use Data Program: Water Resources Division Bulletin, October-December 1978, January-June 1979 , p. 46-47.

2. 1979b, Evaluation of methods for estimating ground-water withdrawals in western Kansas: U.S. Geological Survey Water-Resources Investigations $79-92,70 \mathrm{p}$.

3. Bevans, H. E., 1980, A procedure for predicting concentrations of dissolved solids and sulfate ion in streams draining areas strip mined for coal: U.S. Geological Survey Water-Resources Investigations, Open-File Report 80-764, $17 \mathrm{p}$.

4. Bevans, H. E., and Diaz, A. M., 1980, Statistical summaries of water-quality data for streams draining coal-mined areas, southeastern Kansas: U.S. Geological Survey Hydrologic Data, Open-File Report 80-350, p. 42 p.

5. Carswel1, W. J., Jr., 1979, Multiyear low flow in southeastern Kansas: U.S. Geological Survey Water-Resources Investigations, Open-File Report 791288,26 p.

6. Carswel1, W. J., Jr., and Bond, S. V., 1980, Multiyear low flow of streams in northeastern Kansas: U.S. Geological Survey Water-Resources Investigations, Open-File Report 80-734, 26 p.

7. Denne, J. E., 1979, Uncovering buried valleys in northeastern Kansas: Kansas Geological Survey, The Journal, v. 1, no. 3, 4, p.

8. Dunlap, L. E., 1980, Simulated water-level declines near Marienthal, westcentra1 Kansas: U.S. Geological Survey Water-Resources Investigations 80-39, $15 \mathrm{p}$.

9. Gogel, A. J., 1979, Di scharge of sal twater from Permian rocks to major streamaquifer systems in central and south-central Kansas: U.S. Geological Survey Open-File Report 79-1055, 79 p.

10. Gutentag, E. D., Lobmeyer, D. H., and Slagle, S. E., 1980, Geohydrology of southwestern Kansas: U.S. Geological Survey Open-File Report 80-218, 97 p.

11. Jordan, .P. R., 1979a, Relation of sediment yield to climatic and physical characteristics in the Missouri River basin: U.S. Geological Survey WaterResources Investigations $79-49,26 \mathrm{p}$.

12. 1979b, Statistical summary of streamflow data for Kansas streams in the Missouri River basin: Kansas Water Resources Board Technical Report No. 14B, $334 \mathrm{p}$.

13. Kume, Jack, Dunlap, L. E., Gutentag, E. D., and Thomas, J. G., 1979, Hydrologic and related data for water-supply in an intensive-study area, northeastern Wichita County, Kansas: U.S. Geological Survey Water-Resources Investigations $79-105,51 \mathrm{p}$. 
14. Lobmeyer, D. H., and Weakly, E. C., 1979, Water in the Dakota Formation, Hodgeman and northern Ford Counties, southwestern Kansas: Kansas Geological Survey Irrigation Series 5, $41 \mathrm{p}$.

15. Longwill, S. M., McNellis, J. M., and Posson, D. R., 1980, The use of minicomputers in a distributed information processing system--a feasibility study: U.S. Geological Survey, Open-File Report 80-326, 68 p.

16. McGovern, H. E., and Combs, L. J., 1979, Water-resources investigations in Kansas--fiscal year 1978: U.S. Geological Survey Open-File Report 79-561, $85 \mathrm{p}$.

17. Osterkamp, W. R., 1979a, Bed-and bank-sampling procedure at channel-geometry sites: National Conference on Quality Assurance of Environmental Measurements; Information Transfer Inc., p. 86-89.

18. 1979b, Variation of alluvial-channel width with discharge and character of sediment: U.S. Geological Survey Water-Resources Investigations 79-15, $11 \mathrm{p}$.

19. 1979c, Invariant power functions as applied to fluvial morphology; in Rhodes, D. D., and Williams, G. R., eds., Adjustments of the fluvial system: Kendall/Hunt Publishing Co., p. 33-54.

20. 1980, Sediment-morphology relations of alluvial channels: American Society Civil Engineers Proceedings, Watershed Management Symposium, Boise, Idaho, $12 \mathrm{p}$.

21. Osterkamp, W. R., and Hedman, E. R., 1979, Discharge estimates in surfacemine areas using channel-geometry techniques: Proceedings-Symposium on Surface-Mine Hydrology, Sedimentology and Reclamation, University of Kentucky Bulletin 119, p. 43-49.

22. Osterkamp, W. R., McNellis, J. M., and Jordan, P. R., 1979, Guidel ines for the use of structural versus regression analysis in geomorphic studies: U.S. Geological Survey Water-Resources Investigations 78-135, 22 .

23. Osterkamp, W. R., and Wiseman, A. G., 1980, Particle-size analyses of bed and bank material from channels of the Missouri River basin: U.S. Geological Survey Hydrologic Data, Open-File Report 80-429, 31 p.

24. Pabst, M. E., 1979a, Januaary 1979 water levels, and data related to waterlevel changes, western and south-central Kansas: U.S. Geological Survey Open-File Report 79-925, 213 p.

25. 1979b, Maps showing saturated thickness, January 1979, and percentage decrease in saturated thickness, 1950-79, of unconsolidated aquifer in westcentral Kansas: U.S. Geological Survey Open-File Report 79-1340, 3 p., $2 \mathrm{pl}$.

26. Pabst, M. E., and Gutentag, E. D., 1979, Water-1evel changes in southwestern Kansas 1940-78: Kansas Geological Survey Journal, May 1979, 29 p. 
27. Peek, C. 0., and Jordan, P. R., 1978, Determination of peak discharge from rainfall data for urbanized basins, Wichita, Kansas: U.S. Geological Survey Open-File Report 78-974, 49 p.

28. Rosenshein, J. S., 1979, Groundwater in the United States 1975-78: American Geophysical Union, Reviews of Geophysics and Space Physics, v. 17, no. 6, September 1979, p. 1240-1253.

29. Rosenshein, J. S., and McNellis, J. M., 1979, WRD prototype mini-computer system in the Kansas District: Water Resources Division Bulletin, OctoberDecember 1977, January-June 1979, p. 42-45.

30. U.S. Geological Survey, 1979a, Flood insurance study, City of Eudora, Kansas: Flood Insurance Administration, U.S. Department of Housing and Urban Development.

31. 1979b, Water resources data for Kansas, water year 1978: U.S. Geological Survey Water-Data Report KS-78-1, 656 p.

32. 1979c, Water resources data for Kansas, 1978: U.S. Geological Survey, pamphlet.

33. 1980a, Flood insurance study, Douglas County, Kansas: Flood Insurance Administration, U.S. Department of Housing and Urban Development.

34. 1980b, Flood insurance study, City of Perry, Kansas: Flood Insurance Administration, U.S. Department of Housing and Urban Development.

35. 1980c, Flood insurance study, City of Wamego, Kansas: Flood Insurance Administration, U.S. Department of Housingand Urban Development.

36. 1980d, Water resources data for Kansas, water year 1979--volume 1. Missouri River basin: U.S. Geological Survey Water-Data Report KS-79-1, $372 \mathrm{p}$.

37. 1980e, Water resources data for Kansas, water year 1979--volume 2. Arkansas River basin: U.S. Geological Survey Water-Data Report KS-79-2, $362 \mathrm{p}$. 
Explanation of Table Symbols

\section{Cooperator of Supporting Programs}

ARCA

WDPW

WWD

KDHE

KDOT

KSBA

KWRB

MRB

SCS

CE A

CE KC

CE T

WPRS

EPA

USFW

BENCHMARK

CBR

NASQAN

GWMD1
Arkansas River Compact Administration

City of Wichita, Department of Public Works

City of Wichita, Water Department

Kansas Department of Health and Environment

Kansas Department of Transporation

Kansas State Board of Agriculture

Kansas Water Resources Board

Missouri River Basin Program, Federal

Soil Conservation Service

U.S. Army Corps of Engineers, Albuquerque District

U.S. Army Corps of Engineers, Kansas City District

U.S. Army Corps of Engineers, Tulsa District

U.S. Water and Power Resources Service, Region 7

(formerly U.S. Bureau of Reclamation)

U.S. Environmental Protection Agency

U.S. Fish and Wildlife Service

U.S. Geological Survey, Federal

U.S. Geological Survey, Federal

U.S. Geological Survey, Federal

Western Kansas Groundwater Management District No. 1

\section{Surface-Water Gaging Stations}

\section{Codes for Station Purpose}

B - Benchmark or 1ong-term trend station

C - Current-purpose station

$\mathrm{H}$ - A hydrologic station to meet objective of defining regional streamflow characteristics

$P$ - Principal-stream stations to meet objective of measuring principal unregulated streams

$R$ - A station required for systems analysis of a regulated stream to meet objective of defining regulated flow 
$B$ - Bubble gage

C - Cableway

CSI - Crest-stage indicator

D - Digital recorder (stage)

Dp - Digital recorder (precipitation)

$\mathrm{R}$ - A-35 recorder

$T$ - Telemetering equipment

W - Artificial control

WW - Wire weight

Remarks

A - Also a precipitation station

B - Equipped with digital stage recorder

C - Equipped with A-35 recorder

D - Equipped with wire weight

E - Equipped with bubble gage

$F$ - Also a continuous record station

F - Also a crest-stage partial-record station

Ground-Water Wells

We11 Numbers

Well numbers in these listings indicate the location of wells according to the land subdivisions of the U.S. Bureau of Land Management (fig. 9). An example of a typical well number is 12S 06E 06BCAC in Geary County. The first two digits indicate the township, which in Kansas are nearly all south of the 40 th parallel base line. The second two digits indicate the range east or west of the Sixth Principal Meridian. The last two digits indicate the section in which the well is located. The first letter after those digits denotes the quarter section or 160-acre tract; the second, the quarter-quarter section or 40acre tract; the third, the quarter-quarter-quarter section or 10-acre tract; and the fourth, when used, the quarter-quarter-quarter-quarter section or 2 1/2-acre tract. The quarter sections, quarter-quarter sections, and so forth, are designated $A, B, C$, and $D$ in a counterclockwise direction, beginning with $A$ in the northeast quadrant. If two or more wells are located within the smallest subdivision indicated, the wells are numbered serially.

Water-Level Notes

A - Annual observation

M - Monthly observation

Q - Quarterly observation

$\mathrm{R}$ - Continuous recorder 


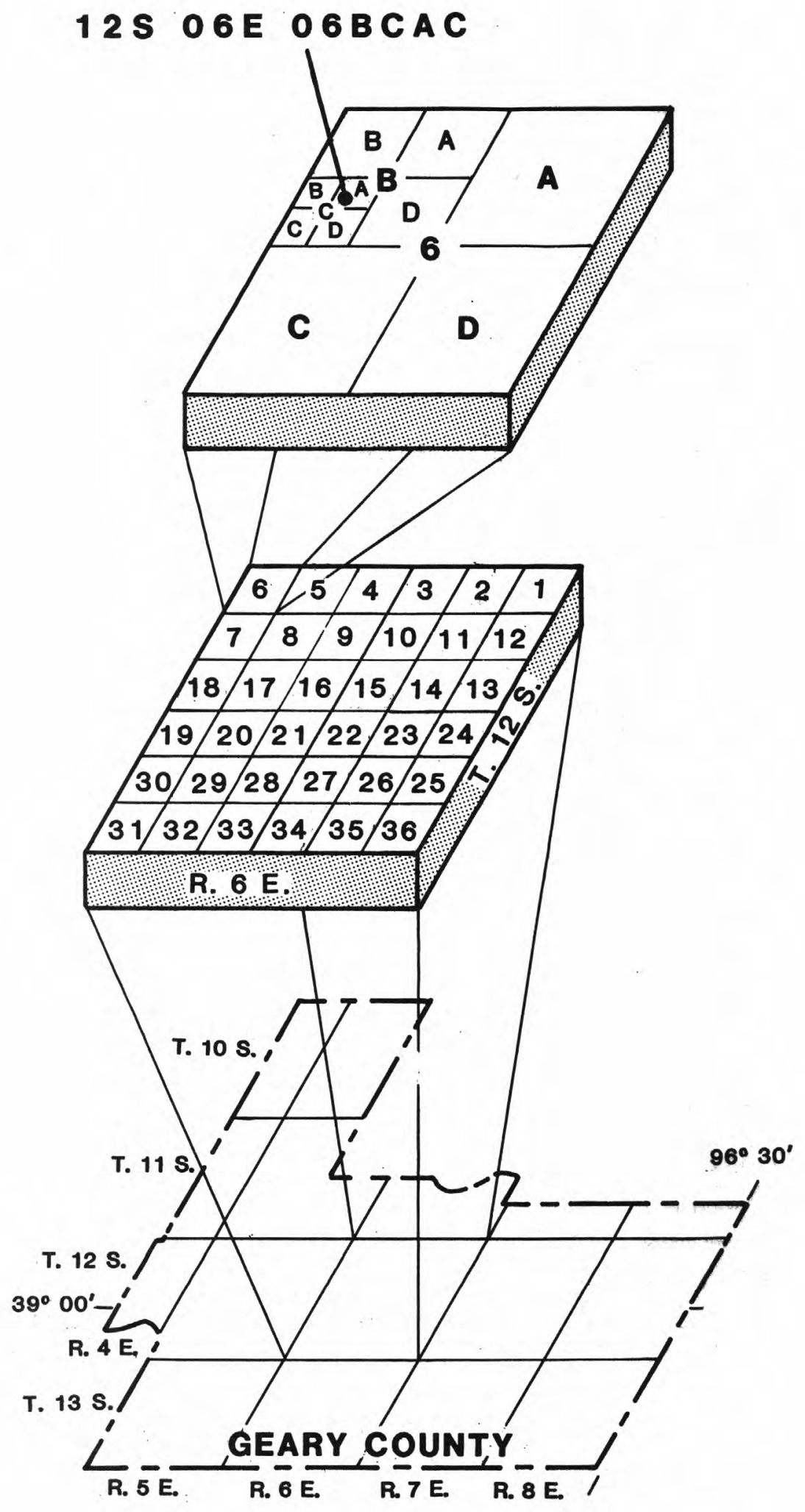

Figure 9.--Wel1-numbering system. 


\section{Sampling Purpose}

$\begin{array}{ll}\text { CHEM } & \text { Chemical analyses, cations, anions, nutrients } \\ \text { CHEMB } & \text { Chemical analyses of bed material } \\ \text { BIOL } & \text { Biological analyses, phytoplankton, periphyton } \\ \text { TOC } & \text { Total organic carbon, suspended, dissolved } \\ \text { METAL } & \text { Trace metals analyses } \\ \text { METALB } & \text { Trace metals analyses of bed material } \\ \text { RAD } & \text { Radiochemical analyses } \\ \text { PEST } & \text { Pesticide analyses } \\ \text { PESTB } & \text { Pesticide analyses of bed material } \\ \text { SEDPT } & \text { Suspended sediment, point analyses } \\ \text { SED } & \text { Suspended sediment, particle analyses } \\ \text { BED } & \text { Bed material, particle analyses } \\ \text { COLI } & \text { Coliform, total, fecal, and fecal streptococcal } \\ \text { COAL } & \text { Coal separation } \\ \text { FIELD } & \text { Field measurements; discharge, water temperature, alkalinity, conduc- } \\ & \text { tance, pH, dissolved oxygen } \\ \text { OBS } & \text { Field observer collects sample for conductance, chloride, and water }\end{array}$

\section{Frequency of Sampling}

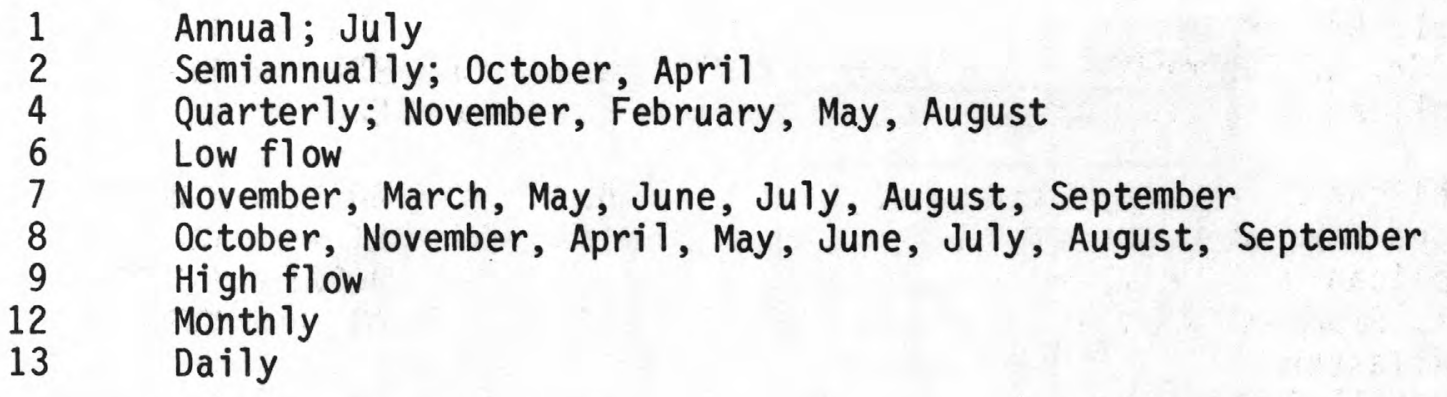

\section{Remarks}

$\begin{array}{cl}\text { MONITOR } & \text { Water quality automatic monitor, water temperature, conductance } \\ 1 & \text { Sediment samples sent to Corps of Engineers, Tulsa District } \\ 2 & \text { Sediment sample above } 30 \text { cubic feet per second } \\ 4 & \text { Sediment sample above } 50 \text { cubic feet per second } \\ 5 & \text { Sediment sample above } 100 \text { cubic feet per second } \\ 6 & \text { Sediment sample above } 150 \text { cubic feet per second } \\ 7 & \text { Sediment sample above } 200 \text { cubic feet per second } \\ 8 & \text { Sediment sample above } 400 \text { cubic feet per second }\end{array}$


Table 1.--Complete-record surface-water gaging stations

Missouri River Basin

Ident.

no.

06-
Station name
Station
purpose $\frac{\text { Location }}{\text { Sec. T. R. }}$
Coop.

$\begin{array}{lll}\text { of } & \text { or } & \text { Remarks } \\ \text { gage } & \text { support }\end{array}$

\begin{tabular}{|c|c|c|c|c|c|c|c|c|}
\hline $\begin{array}{l}8140 \\
8447 \\
8449 \\
8465 \\
8479\end{array}$ & $\begin{array}{l}\text { Turkey Cr. nr Seneca } \\
\text { S. Fk. Sappa Cr. nr Brewster } \\
\text { S. Fk. Sappa Cr. nr Achilles } \\
\text { Beaver Cr. at Cedar Bluffs } \\
\text { Prairie Dog Cr. ab Norton Res. }\end{array}$ & $\begin{array}{l}\mathrm{C} \\
\mathrm{H} \\
\mathrm{C}, \mathrm{C}, \mathrm{P}\end{array}$ & $\begin{array}{r}20 \\
9 \\
29 \\
10 \\
23\end{array}$ & $\begin{array}{l}1 S \\
9 S \\
4 S \\
1 S \\
3 S\end{array}$ & $\begin{array}{l}12 E \\
37 W \\
30 W \\
29 W \\
25 W\end{array}$ & $\begin{array}{l}\text { BDR } \\
\text { BR } \\
\text { BR } \\
\text { BR } \\
\text { BCDRW }\end{array}$ & $\begin{array}{l}\text { KWRB } \\
\text { KWRB } \\
\text { KWRB } \\
\text { CBR } \\
\text { CE KC }\end{array}$ & $\begin{array}{l}A \\
A \\
A \\
A\end{array}$ \\
\hline $\begin{array}{l}84795 \\
8480 \\
8485 \\
8535 \\
8538\end{array}$ & $\begin{array}{l}\text { Norton Res. nr Norton } \\
\text { Prairie Dog Cr. at Norton } \\
\text { Prairie Dog Cr. nr Woodruff. } \\
\text { Republican R. nr Hardy, Nebr. } \\
\text { White Rock Cr. nr Burr Oak }\end{array}$ & $\begin{array}{l}C, R \\
C, R \\
C, R \\
C\end{array}$ & $\begin{array}{l}8 \\
9 \\
9 \\
6 \\
7\end{array}$ & $\begin{array}{l}3 S \\
3 S \\
1 S \\
1 S \\
2 S\end{array}$ & $\begin{array}{r}23 W \\
23 W \\
19 W \\
5 W \\
8 W\end{array}$ & $\begin{array}{l}\text { BR } \\
\text { BDRW } \\
\text { DR } \\
\text { BDR } \\
\text { BCDRW }\end{array}$ & $\begin{array}{l}\text { KWRB } \\
\text { KWRB } \\
\text { CBR } \\
\text { CBR } \\
\text { CE KC }\end{array}$ & \\
\hline $\begin{array}{l}8539 \\
8540 \\
8558 \\
8559 \\
8560\end{array}$ & $\begin{array}{l}\text { Lovewell Res. nr Lovewell } \\
\text { White Rock } \mathrm{Cr} \text {. at Lovewell } \\
\text { Buffalo } \mathrm{Cr} \text {. } \mathrm{nr} \text { Jamestown } \\
\text { Wolf } \mathrm{Cr} \text {. nr Concordia } \\
\text { Republican R. at Concordia }\end{array}$ & $\begin{array}{l}C, R \\
C \\
H \\
C, R\end{array}$ & $\begin{array}{l}6 \\
17 \\
14 \\
12 \\
28\end{array}$ & $\begin{array}{l}2 S \\
2 S \\
5 S \\
6 S \\
5 S\end{array}$ & $\begin{array}{l}6 W \\
6 W \\
5 W \\
4 W \\
3 W\end{array}$ & $\begin{array}{l}\text { BR } \\
\text { BDRW } \\
\text { BDR } \\
\text { BDR } \\
\text { BDR }\end{array}$ & $\begin{array}{l}\text { KWRB } \\
\text { KWRB } \\
\text { KWRB } \\
\text { KWRB } \\
\text { CE KC }\end{array}$ & \\
\hline $\begin{array}{l}8566 \\
85705 \\
8571 \\
8585\end{array}$ & $\begin{array}{l}\text { Republican R. at } \mathrm{Cl} \text { ay Center } \\
\text { Milford Lake nr Junction City } \\
\text { Republican R. bl Milford Dam } \\
\text { N. Fk. Smoky Hill R. nr } \\
\text { McAllaster }\end{array}$ & $\begin{array}{l}C, R \\
C, R \\
P\end{array}$ & $\begin{array}{l}17 \\
20 \\
-\overline{17}\end{array}$ & $\begin{array}{l}8 S \\
11 S \\
-- \\
12 S\end{array}$ & $\begin{array}{r}3 \mathrm{E} \\
5 \mathrm{E} \\
-- \\
36 \mathrm{~W}\end{array}$ & $\begin{array}{l}\text { BDRT } \\
\text { RT } \\
\text { BCDRT } \\
\text { BR }\end{array}$ & $\begin{array}{l}\text { CBR } \\
\text { CE KC } \\
\text { CE KC } \\
\text { KWRB }\end{array}$ & A \\
\hline 8600 & Smoky Hill R. at Elkader & B & 34 & $14 S$ & $32 W$ & $B D$ & CE KC & A \\
\hline $\begin{array}{l}8610 \\
8615 \\
8620\end{array}$ & $\begin{array}{l}\text { Smoky Hill R. nr Arnold } \\
\text { Cedar Bluff Res. nr Ellis } \\
\text { Smoky Hill R. at Cedar Bluff } \\
\text { Dam }\end{array}$ & $\begin{array}{l}C, P \\
C, R\end{array}$ & $\begin{array}{r}29 \\
36 \\
1\end{array}$ & $\begin{array}{l}14 S \\
14 S \\
15 S\end{array}$ & $\begin{array}{l}24 W \\
22 W \\
22 W\end{array}$ & $\begin{array}{l}\text { BDR } \\
\text { BR } \\
\text { BCRTW }\end{array}$ & $\begin{array}{l}\text { CE KC } \\
\text { KWRB } \\
\text { KWRB }\end{array}$ & \\
\hline $\begin{array}{l}8627 \\
8635\end{array}$ & $\begin{array}{l}\text { Smoky Hill R. nr Schoenchen } \\
\text { Big Cr. nr Hays }\end{array}$ & $\begin{array}{l}C, R \\
C, P\end{array}$ & $\begin{array}{l}25 \\
30\end{array}$ & $\begin{array}{l}15 S \\
14 S\end{array}$ & $\begin{array}{l}19 W \\
17 W\end{array}$ & $\begin{array}{l}\text { BDR } \\
\text { BDR }\end{array}$ & $\begin{array}{l}\text { KWRB } \\
\text { KWRB }\end{array}$ & \\
\hline $\begin{array}{l}8639 \\
86405 \\
8645 \\
8650 \\
8655\end{array}$ & $\begin{array}{l}\text { N. Fk. Big Cr. nr Victoria } \\
\text { Smoky Hill R. nr Bunker Hill } \\
\text { Smoky Hill R. at Ellsworth } \\
\text { Kanopolis Lake nr Kanopolis } \\
\text { Smoky Hill R. nr Langley }\end{array}$ & $\begin{array}{c}C \\
C, R \\
C, R \\
C, R\end{array}$ & $\begin{array}{r}27 \\
33 \\
20 \\
3 \\
35\end{array}$ & $\begin{array}{l}13 S \\
14 S \\
15 S \\
17 S \\
16 S\end{array}$ & $\begin{array}{r}17 W \\
13 W \\
8 W \\
6 W \\
6 W\end{array}$ & $\begin{array}{l}\text { BR } \\
\text { BDR } \\
\text { BDR } \\
\text { BR } \\
\text { BDRT }\end{array}$ & 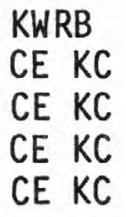 & \\
\hline
\end{tabular}


Table 1.--Complete-record surface-water gaging stations--Continued

Ident.

no.

06-

Station name

$\begin{array}{lllll}\text { Station } & \text { Location } & \begin{array}{l}\text { Type } \\ \text { of }\end{array} & \begin{array}{l}\text { Coop. } \\ \text { or }\end{array} & \text { Remarks } \\ \text { purpose Sec.T. R. } & \text { gage } & \text { support } & \end{array}$

8665 Smoky Hill R. nr Mentor

8670

8681

8682

8695

8702 Smoky Hill R. at New Cambria

8710 N. Fk. Solomon R. at Glade

8715 Bow $\mathrm{Cr}$. nr Stockton

8717 Kirwin Res. at Kirwin

8718 N. Fk. Solomon R. at Kirwin

8719 Deer Cr. nr Phillipsburg

8725

8730

8731

8732

87346

8737

8740

8742

8759

87644 Solomon R. nr Minneapolis

8767 Salt $\mathrm{Cr}$. nr Ada

8769 Solomon R. at Niles

8776

8780

8791 Kansas R. at Ft. Riley

87965 Kings $\mathrm{Cr}$. nr Manhattan

8842 Mil1 $\mathrm{Cr}$. at Washington

8844 Little Blue R. nr Barnes

8855 Black Vermillion R. nr Frankfort

8869 Tuttle Creek Lake nr Manhattan

8870 Big Blue R. nr Manhattan

8875 Kansas R. at Wamego

8885 Mill Cr. nr Paxico

8890 Kansas R. at Topeka

$\begin{array}{crrrll}\text { C, R } & 29 & 14 S & 2 W & \text { BDRT } & \text { CE KC } \\ \text { B,C,P } & 34 & 12 S & 14 W & \text { BDR } & \text { KWRB } \\ & 36 & 12 S & 11 W & \text { RT } & \text { CE KC } \\ \text { C,R } & 25 & 12 S & 11 W & \text { BDRT } & \text { CE KC } \\ \text { C,R } & 16 & 12 S & 5 W & \text { BDRT } & \text { KWRB }\end{array}$

$\begin{array}{llllll}C, R & 8 & 14 S & \text { IW } & \text { BDR } & \text { MRB }\end{array}$

$\begin{array}{llll}C, P & 25 & 4 S & 18 W \\ C & \text { BDR } & \text { CE KC }\end{array}$

$\begin{array}{llllll}C & 1 & 6 \mathrm{~S} & 18 \mathrm{~W} & \mathrm{BDR} & \mathrm{CBR}\end{array}$

33 4S 16W BR KWRB

$\begin{array}{llllll}C, R & 33 & 4 S & 16 \mathrm{~W} & \mathrm{R} & \text { KWRB }\end{array}$

$\begin{array}{llllll}H & 24 & 3 S & 10 W & \text { BDR } & \text { KWRB }\end{array}$

$\begin{array}{llllll}C, R & 5 & 6 S & 12 W & B D R & C E \\ C\end{array}$

$\begin{array}{lllll}C, P & 8 & 8 S & 20 W & B D R\end{array}$

$\begin{array}{llllll} & 27 & 7 S & 19 W & \text { BR } & \text { KWRB } \\ C, R & 26 & 7 S & 19 W & \text { BCDR } & \text { KWRB }\end{array}$

$\begin{array}{llllll}C & 16 & 7 \mathrm{~S} & 16 \mathrm{~W} & \mathrm{BR} & \text { WPRS }\end{array}$

$\begin{array}{llllll}H & 11 & 8 S & 14 W & B R & \text { KWRB }\end{array}$

$\begin{array}{llllll}C, R & 20 & 7 S & 12 W & B D R & \text { KWRB }\end{array}$

$\begin{array}{lllll}27 & 6 S & 9 W & B R & \text { WPRS }\end{array}$

$\begin{array}{llllll}C, R & 2 & 7 S & 9 W & B C D R W & K W R B\end{array}$

$\begin{array}{llllll}C & 1 & 11 S & 4 W & B R & W P R S\end{array}$

$\begin{array}{llllll}C & 36 & 10 S & 5 W & \text { BDR } & \text { KWRB }\end{array}$

$\begin{array}{lllll}C, R & 31 & 12 S & 1 W \\ C, R D R T & C E ~ K C\end{array}$

$\begin{array}{lllll}C, R & 20 & 13 S & 3 E & B D R T \\ H\end{array}$

$\begin{array}{llllll}H & 1 & 12 S & 3 E & \text { BDR } & \text { KWRB }\end{array}$

$\begin{array}{crrrll}C, R & 33 & 11 S & 6 E & \text { BDRT } & \text { CE KC } \\ & 18 & 11 S & 8 E & \text { BDR } & \text { CBR } \\ H & 1 & 3 S & 3 E & \text { BDR } & \text { KWRB } \\ \text { C ,P } & 22 & 3 S & 5 E & \text { BDR } & \text { CE KC } \\ \text { C } & 20 & 4 S & 9 E & \text { BDR } & \text { CE KC }\end{array}$

24 9S 7E BR $\quad$ CE KC

$\begin{array}{llllll}C, R & 30 & 9 S & 8 \mathrm{E} & \mathrm{BDRT} & \mathrm{CE} \mathrm{KC}\end{array}$

$\begin{array}{lllll}C, R & 9 & 10 S & 10 E & B D R T \\ C\end{array}$

$\begin{array}{llllll}C & 27 & 11 S & 11 \mathrm{E} & \mathrm{BDRT} & \mathrm{KWRB}\end{array}$

$\begin{array}{lllll}C, R & 28 & 11 S & 16 E & \text { BDRT }\end{array}$ 
Ident.

no.

06-
Station name

$\begin{array}{ll}8891 & \text { Soldier } \mathrm{Cr} . \mathrm{nr} \text { Goff } \\ 88912 & \text { Soldier } \mathrm{Cr} \text {. nr Bancroft } \\ 88914 & \text { Soldier } \mathrm{Cr} \text {. nr Soldier } \\ 88916 & \text { Soldier } \mathrm{Cr} \text {. nr Circleville } \\ 88918 & \text { Soldier } \mathrm{Cr} . \mathrm{nr} \text { St. Clere } \\ & \\ 8892 & \text { Soldier } \mathrm{Cr} . \mathrm{nr} \text { Delia } \\ 8895 & \text { Soldier } \mathrm{Cr} . \mathrm{nr} \text { Topeka } \\ 8901 & \text { Delaware R. nr Muscotah } \\ 890898 & \text { Perry Lake nr Perry } \\ 8909 & \text { Delaware R. bl Perry Dam } \\ & \\ 8910 & \text { Kansas R. at Lecompton } \\ 891478 & \text { Clinton Lake nr Lawrence } \\ 891483 & \text { Wakarusa R. bl Clinton Dam } \\ 8920 & \text { Stranger Cr. nr Tonganoxie } \\ 89235 & \text { Kansas R. at DeSoto } \\ 89308 & \text { Blue R. nr Stanley } \\ 8933 & \text { Indian Cr. at Overland Park } \\ 89335 & \text { Tomahawk Cr. nr Overland Park } \\ 9108 & \text { Marais des Cygnes R. nr } \\ & \text { Reading } \\ 910997 & \text { Melvern Lake nr Melvern }\end{array}$

910997 Melvern Lake nr Melvern

$\begin{array}{crrrrrr}\mathrm{C}, \mathrm{H} & 16 & 5 \mathrm{~S} & 13 \mathrm{E} & \mathrm{BDR} & \text { KWRB } & \text { A } \\ \mathrm{C}, \mathrm{H} & 28 & 5 \mathrm{~S} & 13 \mathrm{E} & \text { BDR } & \text { KWRB } & \text { A } \\ \mathrm{C}, \mathrm{H} & 4 & 6 \mathrm{~S} & 13 \mathrm{E} & \text { BDR } & \text { KWRB } & \text { A } \\ \mathrm{C}, \mathrm{H} & 10 & 7 \mathrm{~S} & 13 \mathrm{E} & \text { BDR } & \text { KWRB } & \text { A } \\ \mathrm{C} & 12 & 8 \mathrm{~S} & 13 \mathrm{E} & \text { BDR } & \text { KWRB } & \text { A }\end{array}$

$\begin{array}{crrrll}C & 5 & 10 S & 14 E & \text { BDR } & \text { CE KC } \\ \text { C } & 14 & 11 S & 15 E & \text { BDR } & \text { CE KC } \\ \text { B,C } & 16 & 6 S & 17 E & \text { BDRT } & \text { CE KC } \\ & 9 & 11 S & 18 E & R & \text { CE KC } \\ C, R & 9 & 11 S & 18 E & C_{2} & \text { CE KC }\end{array}$

$\begin{array}{llllll}C, R & 34 & 11 S & 18 E & \text { BDRT } & \text { CE KC }\end{array}$

8 13S 19E B CE KC

$\begin{array}{lllll}C, R & 15 & 13 S & 19 E & B D R T \\ B\end{array}$

$\begin{array}{lllll}\mathrm{B}, \mathrm{C} & 7 & 11 \mathrm{~S} & 22 \mathrm{E} & \mathrm{BDRT} \\ \mathrm{C} & \mathrm{CE} & \mathrm{KC}\end{array}$

$\begin{array}{lllll}C, R & 28 & 12 S & 22 E & B D R T\end{array}$

$\begin{array}{crrrll}C & 19 & 14 S & 25 E & \text { BDR } & \text { CE KC } \\ \text { C,H } & 6 & 13 S & 25 E & \text { BDR } & \text { KWRB } \\ C & 21 & 13 S & 25 E & \text { BDR } & \text { CE KC } \\ C & 15 & 17 S & 13 E & \text { BDR } & \text { CE KC }\end{array}$

1 18S 15E R CE KC

$\mathrm{B}, \mathrm{C}, \mathrm{H} \quad 34 \quad 16 \mathrm{~S} \quad 16 \mathrm{E} \quad \mathrm{BDR} \quad$ KWRB

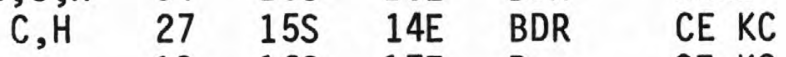

$\begin{array}{lllll}19 & 16 S & 17 E & R & C E \\ C\end{array}$

$\begin{array}{lllll}C, R & 20 & 16 S & 17 E & B C D R T \\ \text { CE KC }\end{array}$

$\begin{array}{llllll}C, R & 7 & 17 S & 18 E & B D R T & C E ~ K C\end{array}$

$\begin{array}{llllll}C, R & 36 & 16 S & 19 E & \text { BDRT } & \text { CE KC }\end{array}$

$\begin{array}{llllll}C & 6 & 20 \mathrm{~S} & 20 \mathrm{E} & \mathrm{BDR} & \text { KWRB }\end{array}$

C 20 16S 23E BCDR CE KC

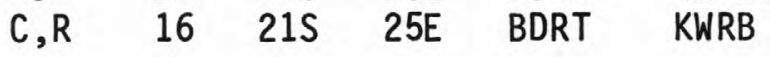

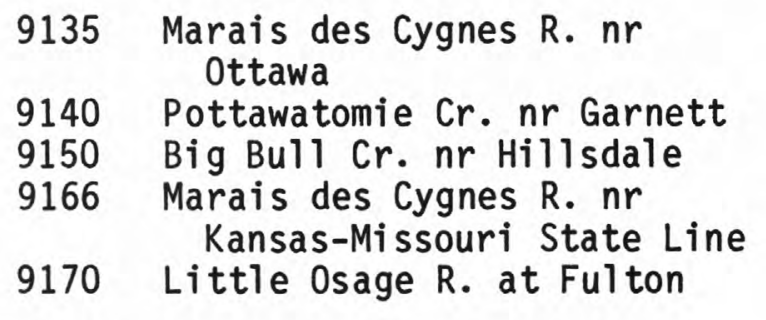

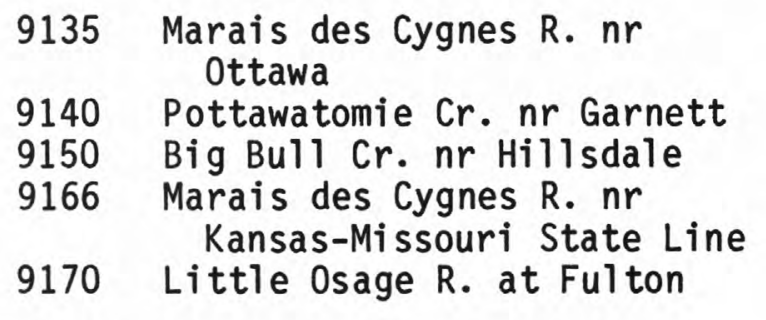

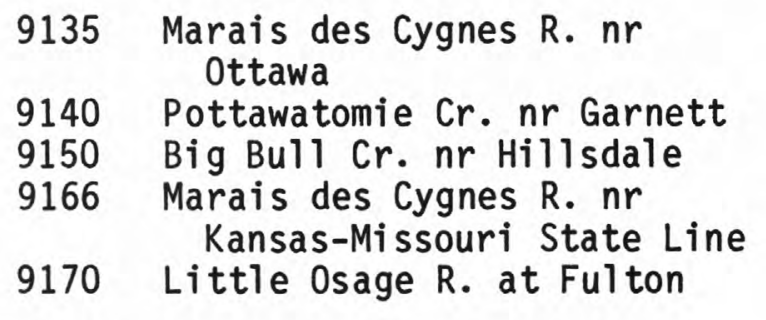

91738 Marmaton R. nr Marmaton

B,C 25 23S 24E BDR KWRB

C $426 \mathrm{~S}$ 24E BCDR CE KC
A
A
A
A

A

A 
Table 1.--Complete-record surface-water gaging stations--Continued

Arkansas River Basin

Ident.

no.

$07-$

Station name

Station

purpose Sec. T. R.

Type Coop.

$\begin{array}{lll}\text { of } & \text { or } & \text { Remarks } \\ \text { gage } & \text { support } & \end{array}$

\begin{tabular}{|c|c|c|c|c|c|c|c|c|}
\hline $\begin{array}{l}1370 \\
1375\end{array}$ & $\begin{array}{l}\text { Frontier Ditch nr Coolidge } \\
\text { Arkansas R. nr Coolidge }\end{array}$ & $\stackrel{C}{C, R}$ & $\begin{array}{l}21 \\
26\end{array}$ & $\begin{array}{l}23 S \\
23 S\end{array}$ & $\begin{array}{l}43 W \\
43 W\end{array}$ & $\begin{array}{l}\text { RRT } \\
\text { BDT }\end{array}$ & $\begin{array}{l}\text { CBR } \\
\text { CBR } \\
\text { ARCA }\end{array}$ & \\
\hline $\begin{array}{l}1380 \\
13865 \\
1395\end{array}$ & $\begin{array}{l}\text { Arkansas R. at Syracuse } \\
\text { Whitewoman } \mathrm{Cr} \text {. nr Leoti } \\
\text { Arkansas R. at Dodge City }\end{array}$ & $\begin{array}{l}C, R \\
C, H \\
C, R\end{array}$ & $\begin{array}{l}18 \\
23 \\
35\end{array}$ & $\begin{array}{l}24 S \\
18 S \\
26 S\end{array}$ & $\begin{array}{l}40 W \\
38 W \\
25 W\end{array}$ & $\begin{array}{l}\text { BDRT } \\
\text { BR } \\
\text { BDRT }\end{array}$ & $\begin{array}{l}\text { KWRB } \\
\text { KWRB } \\
\text { CE A }\end{array}$ & $\begin{array}{l}A \\
A\end{array}$ \\
\hline $\begin{array}{l}1398 \\
1400 \\
1407 \\
1412 \\
1413\end{array}$ & $\begin{array}{l}\text { Mulberry Cr. nr Dodge City } \\
\text { Arkansas R. nr Kinsley } \\
\text { Guzzler s Gulch nr Ness City } \\
\text { Pawnee R. at Larned } \\
\text { Arkansas R. at Great Bend }\end{array}$ & $\begin{array}{l}H \\
C, R \\
H \\
B, C \\
C, R\end{array}$ & $\begin{array}{l}24 \\
26 \\
23 \\
30 \\
33\end{array}$ & $\begin{array}{l}28 S \\
24 S \\
20 S \\
21 S \\
19 S\end{array}$ & $\begin{array}{l}25 W \\
19 W \\
24 W \\
18 W \\
13 W\end{array}$ & $\begin{array}{l}\text { BR } \\
\text { BDRT } \\
\text { BR } \\
\text { BDRW } \\
\text { BDRT }\end{array}$ & $\begin{array}{l}\text { KWRB } \\
\text { CE A } \\
\text { KWRB } \\
\text { KWRB } \\
\text { CE A }\end{array}$ & A \\
\hline $\begin{array}{l}14178 \\
1419 \\
1423 \\
142575 \\
14262\end{array}$ & $\begin{array}{l}\text { Walnut } \mathrm{Cr} \text {. nr Rush Center } \\
\text { Walnut } \mathrm{Cr} \text {. at Albert } \\
\text { Rattlesnake } \mathrm{Cr} \text {. nr Macksville } \\
\text { Rattlesnake } \mathrm{Cr} \text {. nr Zenith } \\
\text { Rattlesnake } \mathrm{Cr} \text {. nr Raymond }\end{array}$ & $\begin{array}{l}C, P \\
C, P \\
P \\
C, P \\
C, P\end{array}$ & $\begin{array}{l}24 \\
29 \\
16 \\
26 \\
15\end{array}$ & $\begin{array}{l}18 S \\
18 S \\
25 S \\
22 S \\
21 S\end{array}$ & $\begin{array}{l}19 W \\
15 W \\
14 W \\
11 W \\
10 W\end{array}$ & $\begin{array}{l}\text { BDR } \\
R \\
B R \\
B R \\
B R\end{array}$ & $\begin{array}{l}\text { KWRB } \\
\text { KWRB } \\
\text { KWRB } \\
\text { USFW } \\
\text { KWRB }\end{array}$ & \\
\hline $\begin{array}{l}14286 \\
1429 \\
1433 \\
14333 \\
143665\end{array}$ & $\begin{array}{l}\text { Cow Cr. nr Claflin } \\
\text { Blood Cr. nr Boyd } \\
\text { Cow Cr. nr Lyons } \\
\text { Arkansas R. nr Hutchinson } \\
\text { Little Ark. R. at Alta Mills }\end{array}$ & $\begin{array}{l}H \\
H \\
C, R \\
C, R \\
H, P\end{array}$ & $\begin{array}{r}6 \\
34 \\
15 \\
21 \\
30\end{array}$ & $\begin{array}{l}18 S \\
17 S \\
20 S \\
24 S \\
22 S\end{array}$ & $\begin{array}{r}11 W \\
14 W \\
8 W \\
4 W \\
2 W\end{array}$ & $\begin{array}{l}\text { BR } \\
\text { BR } \\
\text { BDRT } \\
\text { BDR } \\
\text { BR }\end{array}$ & $\begin{array}{l}\text { KWRB } \\
\text { KWRB } \\
\text { KWRB } \\
\text { KWRB } \\
\text { KWRB }\end{array}$ & \\
\hline 1442 & $\begin{array}{l}\text { Little Ark. R. at Valley } \\
\text { Center }\end{array}$ & $B, C$ & 36 & $25 S$ & $1 W$ & BDR & $\begin{array}{l}\text { KWRB } \\
\text { WDPW }\end{array}$ & \\
\hline 1443 & Arkansas R. at Wichita & $C, P$ & 5 & $28 S$ & $1 E$ & BDRT & $\begin{array}{l}\text { KWRB } \\
\text { WDPW }\end{array}$ & \\
\hline $\begin{array}{l}14455 \\
14478\end{array}$ & $\begin{array}{l}\text { Arkansas R. at Derby } \\
\text { N. Fk. Ninnescah R. ab } \\
\text { Cheney Reservoir }\end{array}$ & $\begin{array}{l}C, P \\
C, P\end{array}$ & $\begin{array}{l}12 \\
25\end{array}$ & $\begin{array}{l}29 S \\
25 S\end{array}$ & $\begin{array}{l}1 E \\
6 W\end{array}$ & $\begin{array}{l}\text { BDRT } \\
\text { BR }\end{array}$ & $\begin{array}{l}\text { CE T } \\
\text { WWD }\end{array}$ & \\
\hline 14479 & Cheney Reservoir at Cheney & & 6 & $27 S$ & $4 W$ & BR & WWD & \\
\hline 144795 & $\begin{array}{l}\text { N. Fk. Ninnescah R. at } \\
\text { Cheney Dam }\end{array}$ & $C, R$ & 6 & $27 S$ & $4 W$ & DW & WWD & \\
\hline 14485 & $\begin{array}{l}\text { S. Fk. S. Fk. Ninnescah R. } \\
\text { nr Pratt }\end{array}$ & $\mathrm{H}$ & 26 & $28 S$ & $14 W$ & BR & KWRB & \\
\hline 1452 & $\begin{array}{l}\text { S. Fk. Ninnescah R. nr } \\
\text { Murdock }\end{array}$ & $C, P$ & 34 & $28 S$ & $5 W$ & $\mathrm{R}$ & KWRB & \\
\hline $\begin{array}{l}1455 \\
1457\end{array}$ & $\begin{array}{l}\text { Ninnescah R. nr Peck } \\
\text { Slate Creek at Wellington }\end{array}$ & $\underset{H}{C, R}$ & $\begin{array}{l}10 \\
23\end{array}$ & $\begin{array}{l}30 S \\
32 S\end{array}$ & $\begin{array}{l}1 W \\
1 W\end{array}$ & $\begin{array}{l}\text { BDR } \\
\text { BR }\end{array}$ & $\begin{array}{l}\text { CE T } \\
\text { KWRB }\end{array}$ & \\
\hline
\end{tabular}


Table 1.--Complete-record surface-water gaging stations--Continued

Ident.

no.

Station name

Type Coop.

07-

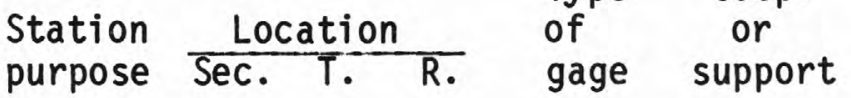

Remarks

1465 Arkansas R. at Arkansas City C,P 35 34S 3E BDRT CBR

14657 Cole Cr. nr DeGraff

14707 Whitewater R. at Towanda

1478 Walnut $R$. at Winfield

1490 Medicine Lodge R. nr Kiowa

1515 Chikaskia R. nr Corbin

15559 Cimarron R. nr Elkhart

15601 N. Fk. Cimarron R. at Richfield

1561 Sand Arroyo $\mathrm{Cr}$. nr Johnson

15622 Bear $\mathrm{Cr}$. nr Johnson

CE T

\begin{tabular}{llllll}
$H$ & 21 & $24 S$ & $6 E$ & BDR & KWRB \\
\hline & 8 & $26 S$ & $4 E$ & BDR & KWRB
\end{tabular}

$\begin{array}{lrrrll}C, P & 8 & 26 S & 4 E & B D R & \text { KWRB } \\ C & 33 & 32 S & 4 E & \text { BDRT } & \text { CE T }\end{array}$

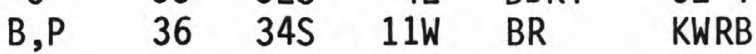

$\begin{array}{llllll}P & 36 & 33 S & 3 W & \text { BDR } & \text { KWRB }\end{array}$

$\begin{array}{llllll}\mathrm{H} & 4 & 34 \mathrm{~S} & 42 \mathrm{~W} & \mathrm{BR} & \text { KWRB }\end{array}$

$\begin{array}{llllll}H & 16 & 32 S & 41 W & \text { BR } & \text { KWRB }\end{array}$

1575 Crooked $\mathrm{Cr}$. nr Nye

157740 Cimarron River nr Buttermilk

1579 Cavalry $\mathrm{Cr}$. at Coldwater

157940 Bluff Creek nr Buttermi 1k

1659 Toronto Lake $\mathrm{nr}$ Toronto

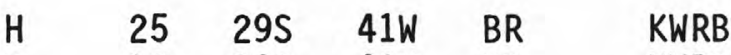

H 12 28S 41W BR KWRB

A

$\mathrm{B}, \mathrm{H} \quad 1 \quad 35 \mathrm{~S} \quad 27 \mathrm{~W}$ BR $\quad$ KWRB

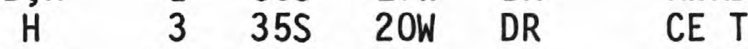

$\mathrm{C}, \mathrm{H} \quad 14$ 32S $19 \mathrm{~W}$ BR

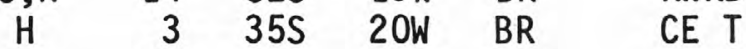

36 26S 13E R CE T

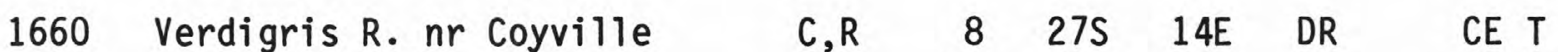

1665 Verdigris R. nr Al toona

1675 otter $\mathrm{Cr}$. at Climax

1680 Fall River Lake nr Fall River

1685 Fall R. nr Fall River

1695 Fall R. at Fredonia

1698 Elk R. at Elk Falls

17005 Elk City Lake nr Independence

17006 Elk R. bl Elk City Lake

1705 Verdigris R. at Independence

$C, R \quad 29$ 29S $16 E$

$\mathrm{B}, \mathrm{H} \quad 8 \quad 27 \mathrm{~S}$

$11 \mathrm{E}$

DR

CE T

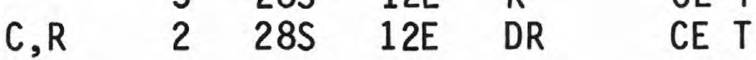

1707 Big Hill Cr. nr Cherryvale

1720 Caney R. nr Elgin

$\begin{array}{llllll}C, R & 24 & 29 S & 14 E & \text { DR } & \text { CE T }\end{array}$

$\begin{array}{llllll}C & 3 & 31 S & 11 \mathrm{E} & \mathrm{BDR} & \text { KWRB }\end{array}$

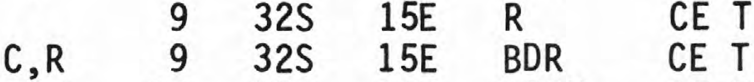

$\begin{array}{lllll}C, R & 32 & 32 S & 16 E & B D R T \\ \end{array}$

1794 Council Grove Lake $n r$

$\begin{array}{lll}\mathrm{C}, \mathrm{H} & 7 & 32 \mathrm{~S}\end{array}$

18E BDR CE T

C 16 35S 10E BDR

Council Grove

1795 Neosho R. at Council Grove

17973 Neosho R. nr Americus

$C, R \quad 14 \quad 16 S$

$C, R \quad 24 \quad 18 S$

$8 \mathrm{E}$

BR

CE T

179794 Marion Lake $\mathrm{nr}$ Marion

179795 Cottonwood R. b1 Marion Lake

$\begin{array}{lll} & 27 & 19 S \\ C, R & 27 & 19 S \\ C, R & 10 & 21 S \\ C, H & 25 & 21 S \\ C, R & 13 & 19 S\end{array}$

$3 \mathrm{E}$

DR

CE T

10E BDRT CE T

1804 Cottonwood R. nr Florence

1805 Cedar Cr. nr Cedar Point

18225 Cottonwood R. nr Plymouth

$\begin{array}{lll}3 E & \text { BR } & \text { CE T } \\ 3 E & \text { BCDR } & \text { CE T } \\ 5 E & \text { BDR } & \text { CE T } \\ 5 E & \text { DR } & \text { KWRB } \\ 9 E & \text { BDR } & \text { CE T }\end{array}$


Table 1.--Complete-record surface-water gaging stations--Continued

\begin{tabular}{|c|c|c|c|c|c|c|c|c|}
\hline $\begin{array}{l}\text { Ident. } \\
\text { no. } \\
07-\end{array}$ & Station name & $\begin{array}{l}\text { Station } \\
\text { purpose }\end{array}$ & $\frac{\text { Lo }}{\operatorname{Sec} .}$ & tion & 5 & $\begin{array}{l}\text { Type } \\
\text { of } \\
\text { gage }\end{array}$ & $\begin{array}{l}\text { Coop. } \\
\text { or } \\
\text { support }\end{array}$ & Remarks \\
\hline 18245 & $\begin{array}{l}\text { John Redmond Res. nr } \\
\text { Burl ington }\end{array}$ & & 9 & $21 S$ & $15 \mathrm{E}$ & BR & CE T & \\
\hline $\begin{array}{l}18251 \\
1830 \\
1835 \\
1840\end{array}$ & $\begin{array}{l}\text { Neosho R. at Burlington } \\
\text { Neosho R. nr Iola } \\
\text { Neosho R. nr Parsons } \\
\text { Lightning Cr. nr McCune }\end{array}$ & $\begin{array}{l}C, R \\
C, R \\
C, R \\
B\end{array}$ & $\begin{array}{r}26 \\
9 \\
33 \\
7\end{array}$ & $\begin{array}{l}21 S \\
25 S \\
31 S \\
32 S\end{array}$ & $\begin{array}{l}15 \mathrm{E} \\
18 \mathrm{E} \\
21 \mathrm{E} \\
22 \mathrm{E}\end{array}$ & $\begin{array}{l}\text { BDR } \\
\text { BCDRT } \\
\text { BDRTW } \\
\text { BDR }\end{array}$ & $\begin{array}{l}\text { CE T } \\
\text { CE T } \\
\text { KWRB } \\
\text { KWRB }\end{array}$ & \\
\hline $\begin{array}{l}1843 \\
18604\end{array}$ & $\begin{array}{l}\text { Cherry Creek at Hallowell } \\
\text { Cow Creek near Weir }\end{array}$ & $\begin{array}{l}C \\
C\end{array}$ & $\begin{array}{l}21 \\
33\end{array}$ & $\begin{array}{l}33 S \\
31 S\end{array}$ & $\begin{array}{l}22 \mathrm{E} \\
25 \mathrm{E}\end{array}$ & $\begin{array}{l}\text { BDR } \\
\text { BDR }\end{array}$ & $\begin{array}{l}\text { KDHE } \\
\text { KDHE }\end{array}$ & \\
\hline
\end{tabular}


Table 2.--Partial-record surface-water gaging stations

Crest-Stage Gage

Ident.

no.

06-

Station name

$\frac{\text { Location }}{\text { Sec. T. R. }} \begin{gathered}\text { or } \\ \text { support }\end{gathered}$

Remarks

Missouri River Basin

\begin{tabular}{|c|c|c|c|c|c|}
\hline $\begin{array}{l}8137 \\
8157 \\
81826 \\
8448\end{array}$ & $\begin{array}{l}\text { Tennessee Cr. trib. nr Seneca } \\
\text { Buttermilk Cr. nr Willis } \\
\text { White Clay Cr. at Atchison } \\
\text { S. Fk. Sappa Cr. trib. nr } \\
\text { Goodland }\end{array}$ & $\begin{array}{r}2 \\
30 \\
1 \\
36\end{array}$ & $\begin{array}{l}3 S \\
3 S \\
6 S \\
8 S\end{array}$ & $\begin{array}{l}12 E \\
18 E \\
20 E \\
39 W\end{array}$ & $\begin{array}{l}\text { KDOT } \\
\text { KDOT } \\
\text { CE KC } \\
\text { KDOT }\end{array}$ \\
\hline 8451 & Long Branch Draw nr Norcatur & 6 & $2 S$ & $25 W$ & KDOT \\
\hline $\begin{array}{l}8460 \\
8462 \\
8476 \\
8482\end{array}$ & $\begin{array}{l}\text { Beaver Cr. at Ludell } \\
\text { Beaver Cr. trib. nr Ludell } \\
\text { Prairie Dog Cr. trib. at Colby } \\
\text { Prairie Dog Cr. trib. nr } \\
\quad \text { Norton }\end{array}$ & $\begin{array}{r}30 \\
2 \\
6 \\
26\end{array}$ & $\begin{array}{l}2 S \\
3 S \\
8 S \\
2 S\end{array}$ & $\begin{array}{l}32 W \\
32 W \\
33 W \\
23 W\end{array}$ & $\begin{array}{l}\text { KWRB } \\
\text { KDOT } \\
\text { KDOT } \\
\text { KDOT }\end{array}$ \\
\hline 8561 & West $\mathrm{Cr} . \mathrm{nr}$ Talmo & 36 & $4 S$ & $3 W$ & KDOT \\
\hline $\begin{array}{l}85632 \\
8568 \\
8605 \\
8630 \\
8634\end{array}$ & $\begin{array}{l}\text { Elk Cr. at Clyde } \\
\text { Moll Cr. nr Green } \\
\text { Hackberry Cr. nr Gove } \\
\text { Smoky Hill R. at Pfeifer } \\
\text { Big Cr. trib. nr Ogallah }\end{array}$ & $\begin{array}{r}26 \\
8 \\
1 \\
30 \\
11\end{array}$ & $\begin{array}{r}5 S \\
8 S \\
13 S \\
15 S \\
13 S\end{array}$ & $\begin{array}{l}1 W \\
4 E \\
29 W \\
16 W \\
22 W\end{array}$ & $\begin{array}{l}\text { CE KC } \\
\text { KDOT } \\
\text { KWRB } \\
\text { CE KC } \\
\text { KDOT }\end{array}$ \\
\hline $\begin{array}{l}8637 \\
8643\end{array}$ & $\begin{array}{l}\text { Big Cr. trib. nr Hays } \\
\text { Smoky Hill R. trib. at } \\
\text { Dorrance }\end{array}$ & $\begin{array}{r}7 \\
12\end{array}$ & $\begin{array}{l}14 S \\
14 S\end{array}$ & $\begin{array}{l}17 W \\
12 W\end{array}$ & $\begin{array}{l}\text { KDOT } \\
\text { KDOT }\end{array}$ \\
\hline $\begin{array}{l}8647 \\
86649 \\
8668\end{array}$ & $\begin{array}{l}\text { Spring } \mathrm{Cr} \text {. nr Kanopolis } \\
\text { Dry Cr. at Mentor } \\
\text { Saline R. trib. at Collyer }\end{array}$ & $\begin{array}{l}24 \\
24 \\
32\end{array}$ & $\begin{array}{l}15 S \\
15 S \\
11 S\end{array}$ & $\begin{array}{r}8 W \\
3 W \\
25 W\end{array}$ & $\begin{array}{l}\text { KDOT } \\
\text { CE KC } \\
\text { KDOT }\end{array}$ \\
\hline $\begin{array}{l}8683 \\
8684 \\
8689 \\
86995 \\
8703\end{array}$ & $\begin{array}{l}\text { Coon Cr. trib. nr Luray } \\
\text { Wolf } \mathrm{Cr} \text {. nr Lucas } \\
\text { Bull foot } \mathrm{Cr} \text {. trib. nr Lincoln } \\
\text { Mulberry } \mathrm{Cr} \text {. nr Salina } \\
\text { Gypsum Cr. nr Gypsum }\end{array}$ & $\begin{array}{r}19 \\
33 \\
30 \\
9 \\
15\end{array}$ & $\begin{array}{l}10 S \\
11 S \\
12 S \\
14 S \\
16 S\end{array}$ & $\begin{array}{r}12 W \\
11 W \\
7 W \\
3 W \\
1 W\end{array}$ & $\begin{array}{l}\text { KDOT } \\
\text { KWRB } \\
\text { KDOT } \\
\text { CE KC } \\
\text { KWRB }\end{array}$ \\
\hline $\begin{array}{l}8726 \\
8733 \\
8745 \\
8758 \\
87712\end{array}$ & $\begin{array}{l}\text { Oak } \mathrm{Cr} \text {. at Bellaire } \\
\text { Ash } \mathrm{Cr} \text {. trib. nr Stockton } \\
\text { East Limestone } \mathrm{Cr} \text {. nr Ionia } \\
\text { Limestone } \mathrm{Cr} \text {. nr Glen Elder } \\
\text { Mud } \mathrm{Cr} \text {. at Abilene }\end{array}$ & $\begin{array}{l}15 \\
18 \\
21 \\
15 \\
17\end{array}$ & $\begin{array}{r}3 S \\
7 S \\
4 S \\
6 S \\
13 S\end{array}$ & $\begin{array}{r}12 W \\
18 W \\
9 W \\
9 W \\
2 E\end{array}$ & $\begin{array}{l}\text { KDOT } \\
\text { KDOT } \\
\text { KDOT } \\
\text { KWRB } \\
\text { CE KC }\end{array}$ \\
\hline
\end{tabular}


I dent.

no.

06-
Station name

8775 Turkey $\mathrm{Cr}$. $\mathrm{nr}$ Abilene

8785 Lyon Cr. $\mathrm{nr}$ Woodbine

8792 Clark $\mathrm{Cr}$. nr Junction City

879815 Wildcat $\mathrm{Cr}$. at Manhattan

87982 Kansas R. at Manhattan

8841 Mulberry Cr. trib. nr Haddam

8843

8847

8849

88549

Mill $\mathrm{Cr}$. trib. nr Washington

Big Blue R. nr Blue Rapids

Robidoux $\mathrm{Cr}$. at Beattie

Black Vermillion R. at

Frankfort (Hwy 99)

8865 Fancy $\mathrm{Cr}$. at Winkler

8872 Cedar Cr. nr Manhattan

8876 Kansas R. trib. $n r$ Wamego

8880 Vermillion $\mathrm{Cr}$. $\mathrm{nr}$ Wamego

88803 Vermillion $\mathrm{Cr}$. nr Louisville

8883 Rock Cr. nr Louisville

8884

8889

Kansas R. at Maple Hill

Blacksmith Cr. trib. nr Valencia

88955 Indian $\mathrm{Cr}$. $\mathrm{nr}$ Topeka

88963 Shunganunga $\mathrm{Cr}$. at Topeka

89105 Stone House $\mathrm{Cr}$. at Will iamstown 30

89165

89185

8928

89294

Naismith $\mathrm{Cr}$. at Lawrence

Stranger $\mathrm{Cr}$. at Easton

Turkey $\mathrm{Cr}$. at Merriam

Turkey $\mathrm{Cr}$. at Kansas City

89295 Kansas R. at Kansas City

9114

9123

9137

91425

Marai

Dragoon $\mathrm{Cr}$. trib. nr Lyndon

Middle $\mathrm{Cr}$. nr Princeton

S. Fk. Pottawatomie $\mathrm{Cr}$. trib nr Garnett

9145

9151

9167

9171

9174
Pottawatomie $\mathrm{Cr}$. at Lane

Big Bull Cr. at Paola

Middle $\mathrm{Cr}$. nr Kincaid

Marmaton R. $\mathrm{nr}$ Bronson

Marmaton R. trib. $n r$ Fort Scott $\frac{\text { Location }}{\text { Sec. T. R. }}$

Coop.

or

support
Remarks

KWRB

CE KC

CE

KWRB

KWRB

CE KC

CE

KDOT

KDOT

CE KC

KDOT

CE KC

$A B$

CE

D

KWRB

KDOT

KDOT

CE KC

CE KC

KWRB

CE KC

KDOT

CE KC

KC CE

KDOT

KWRB

CE KC

KWRB

KWRB

CE KC

CE KC

KDOT

KDOT

KDOT

CE KC

CE KC

KDOT

KDOT

KDOT
D

D

BCE

CE

D 
Table 2.--Partial-record surface-water gaging stations--Continued

Ident.

no.

$07-$

Station name

$\frac{\text { Location }}{\text { Sec. T. R. }}$

Coop.

or

Remarks

support

\section{Arkansas River Basin}

1386 Whitewoman $\mathrm{Cr}$. trib. nr Selkirk 34

1390 Arkansas R. at Garden City -

1397 Arkansas R. trib. nr Dodge City 11

1403 Whitewoman $\mathrm{Cr}$. $\mathrm{nr}$ Bellefont 33

$175 \quad 39 W$

KDOT

A

$24 \mathrm{~S} 32 \mathrm{~W}$

KWRB

CE

$27 \mathrm{~S} 25 \mathrm{~W}$

KDOT

24S 21W

KDOT

Pawnee R. trib. nr Kalvesta 12

235

$28 \mathrm{~W}$

KDOT

$A B$

$A B$

$A$

1416 Long Branch Cr. nr Ness City 32 18S 23W KDOT

A

1418 Otter $\mathrm{Cr}$. nr Rush Center

$15 \quad 19 \mathrm{~S} \quad 18 \mathrm{~W}$

KDOT

1421 Rattlesnake $\mathrm{Cr}$. trib. $\mathrm{nr}$

$2028 \mathrm{~S} \quad 19 \mathrm{~W}$

KDOT

$A B$

Mullinville

1427 Salt $\mathrm{Cr}$. nr Partridge $22 \quad 235 \quad 7 \mathrm{~W}$

KDOT

143

Cheyenne $\mathrm{Cr}$. trib. $\mathrm{nr}$ Claflin

$28 \quad 18 S \quad 11 W$

KDOT

1436 Little Arkansas R. nr Little 8 19S 6W

KWRB

River

14422 Chisholm Cr. at 69th St. N., Wichita

14423 W. Br. Chisholm Cr. at 61s St. N., Wichita

14424 N. Fk. Chisholm Cr. at 45th St. N., Wichita

$4 \quad 26 S \quad 1 E$

WDPW

C

$17 \quad 26 S \quad 1 E$

WDPW

C

$27 \quad 26 S \quad 1 E$

WDPW

C

14432 Gypsum $\mathrm{Cr}$. at Gilbert St., Wichita

$29 \quad 27 S \quad 2 E$

WDPW

C

144323 Fabrique Br. Gypsum Cr. at Harry St., Wichita

144325 Gypsum $\mathrm{Cr}$. at 01 iver St. Wichita

14433 Dry Cr. at Lincoln St., Wichita

14434 Dry Cr. at Pawnee Ave., Wichita

36

$36 \quad 27 S \quad 1 E$

WDPW

$A B$

$228 \mathrm{~S} \quad 1 \mathrm{E}$

WDPW

C

$25 \quad 27 S \quad 1 E$

WDPW

$A B$

$228 S \quad 1 E$

WDPW

$A B$

144494 Cowskin Cr. trib. at Westfield Drive, Wichita

20

$27 S \quad 1 W$

WDPW

C

30

$275 \quad 1 W$

WDPW

C water Road, Wichita

$26 S 1 W$

WDPW

C Wichita

14453 Spring Cr. at Woodlawn St.,

$29 \quad 29 S \quad 2 E$

WDPW

C

1449 S. Fk. Ninnescah R. trib. nr

$27 \mathrm{~S} \quad 13 \mathrm{~W}$

KDOT

1453 clear Cr. nr. Garden Plain

33

$27 S \quad 3 W$

87

KDOT 
Table 2.--Partial-record surface-water gaging stations--Continued

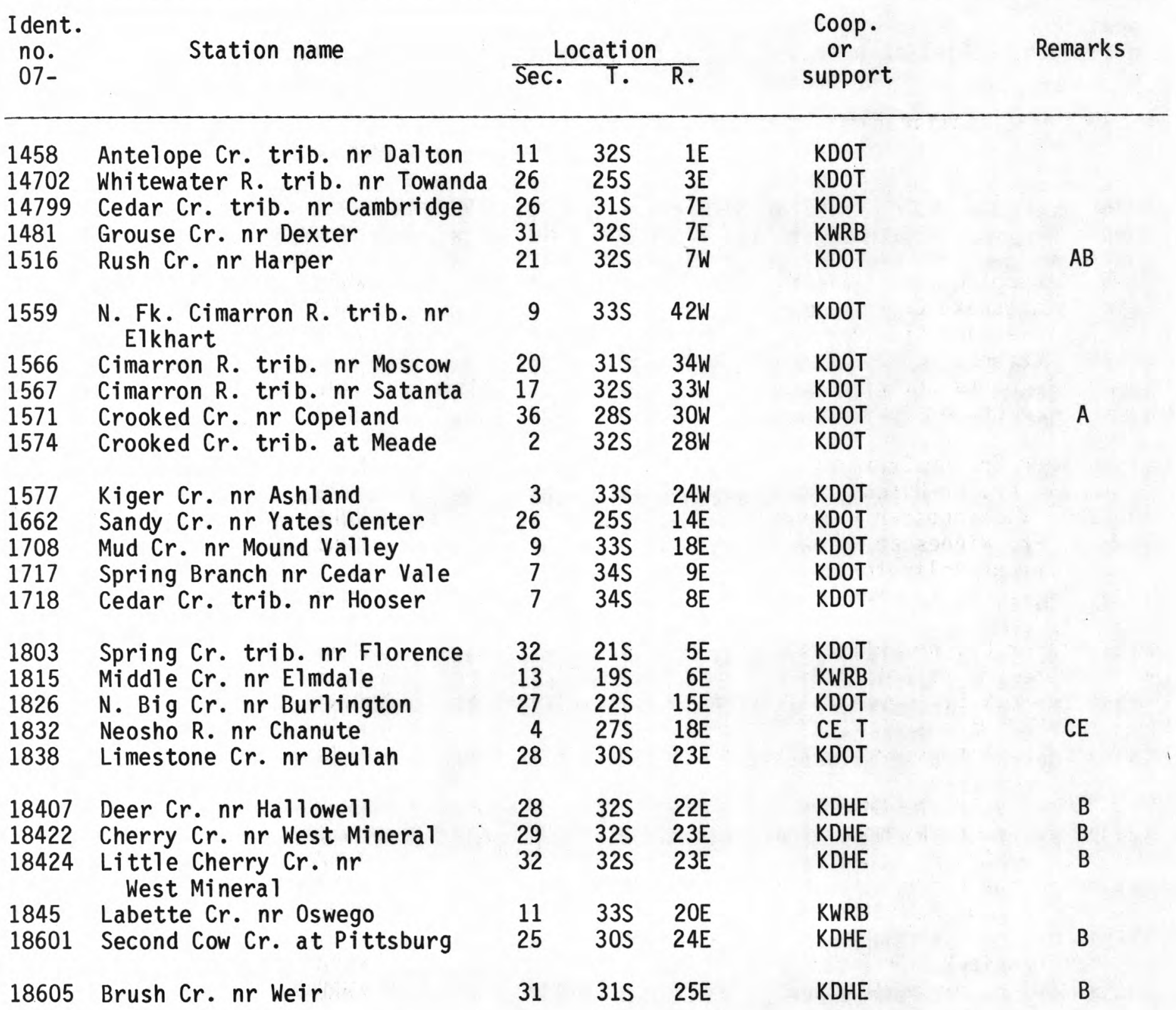


Table 2.--Partial-record surface-water gaging stations--Continued

Low-Fl ow Gage

Ident.

no.

07-

Station name

$\frac{\text { Location }}{\text { Sec. T. R. }}$

Coop.

or

Remarks

support

Arkansas River Basin

\begin{tabular}{|c|c|c|c|c|c|}
\hline $\begin{array}{l}14124 \\
14220 \\
14227\end{array}$ & $\begin{array}{l}\text { Pickerel Cr. nr Larned } \\
\text { Rattlesnake } \mathrm{Cr} \text {. nr Haviland } \\
\text { Rattlesnake } \mathrm{Cr} \text {. trib. nr } \\
\text { Hopewell }\end{array}$ & $\begin{array}{l}33 \\
10 \\
29\end{array}$ & $\begin{array}{l}21 S \\
27 S \\
25 S\end{array}$ & $\begin{array}{l}15 \mathrm{~W} \\
17 \mathrm{~W} \\
15 \mathrm{~W}\end{array}$ & $\begin{array}{l}\text { KWRB } \\
\text { KWRB } \\
\text { KWRB }\end{array}$ \\
\hline $\begin{array}{l}14254 \\
14265\end{array}$ & $\begin{array}{l}\text { Wild Horse Cr. nr St. John } \\
\text { Peace Cr. nr Sylvia }\end{array}$ & $\begin{array}{l}9 \\
4\end{array}$ & $\begin{array}{l}23 S \\
23 S\end{array}$ & $\begin{array}{l}13 W \\
10 W\end{array}$ & $\begin{array}{l}\text { KWRB } \\
\text { KWRB }\end{array}$ \\
\hline $\begin{array}{l}14267 \\
14274 \\
14459 \\
14462\end{array}$ & $\begin{array}{l}\text { Peace Cr. nr Sterling } \\
\text { Salt Cr. nr Hutchinson } \\
\text { N. Fk. Ninnescah R. nr Sylvia } \\
\text { N. Fk. Ninnescah R. ab Silver } \\
\text { Cr. nr Arlington }\end{array}$ & $\begin{array}{r}7 \\
1 \\
27 \\
25\end{array}$ & $\begin{array}{l}22 S \\
23 S \\
24 S \\
25 S\end{array}$ & $\begin{array}{r}8 W \\
7 W \\
10 W \\
8 W\end{array}$ & $\begin{array}{l}\text { KWRB } \\
\text { KWRB } \\
\text { KWRB } \\
\text { KWRB }\end{array}$ \\
\hline 14464 & Silver $\mathrm{Cr}$. $\mathrm{nr}$ Landon & 8 & $26 S$ & $9 \mathrm{~W}$ & KWRB \\
\hline $\begin{array}{l}14466 \\
14468 \\
14474 \\
14489 \\
14513\end{array}$ & $\begin{array}{l}\text { Silver Cr. nr Arlington } \\
\text { Goose Cr. nr Arlington } \\
\text { Red Rock Cr. nr Castleton } \\
\text { S. Fk. Ninnescah R. at Pratt } \\
\text { S. Fk. Ninnescah R. nr Calista }\end{array}$ & $\begin{array}{r}28 \\
4 \\
5 \\
3 \\
1\end{array}$ & $\begin{array}{l}25 S \\
26 S \\
25 S \\
28 S \\
27 S\end{array}$ & $\begin{array}{r}8 W \\
8 W \\
6 W \\
13 W \\
9 W\end{array}$ & $\begin{array}{l}\text { KWRB } \\
\text { KWRB } \\
\text { KWRB } \\
\text { KWRB } \\
\text { KWRB }\end{array}$ \\
\hline $\begin{array}{l}14522 \\
14820 \\
14858 \\
14860 \\
14890\end{array}$ & $\begin{array}{l}\text { Smoot s Cr. nr Murdock } \\
\text { Mule Cr. nr Wilmore } \\
\text { Turkey Cr. nr Croft } \\
\text { Medicine Lodge R. at Sun City } \\
\text { Elm Cr. at Medicine Lodge }\end{array}$ & $\begin{array}{r}6 \\
3 \\
27 \\
2 \\
12\end{array}$ & $\begin{array}{l}28 S \\
32 S \\
29 S \\
31 S \\
32 S\end{array}$ & $\begin{array}{l}5 W \\
16 W \\
15 W \\
15 W \\
12 W\end{array}$ & $\begin{array}{l}\text { KWRB } \\
\text { KWRB } \\
\text { KWRB } \\
\text { KWRB } \\
\text { KWRB }\end{array}$ \\
\hline $\begin{array}{l}1512 \\
15129\end{array}$ & $\begin{array}{l}\text { Chikaskia R. nr Zenda } \\
\text { Sand } \mathrm{Cr} \text {. } \mathrm{nr} \text { Zenda }\end{array}$ & $\begin{array}{l}34 \\
27\end{array}$ & $\begin{array}{l}29 S \\
30 S\end{array}$ & $\begin{array}{l}9 W \\
9 W\end{array}$ & $\begin{array}{l}\text { KWRB } \\
\text { KWRB }\end{array}$ \\
\hline
\end{tabular}


Table 3.--Ground-water-level observation wells

County

Allen

Barber

Barton

Bourbon

Cherokee

Cheyenne

Clark

Clay

Cloud

Comanche

Crawford

Decatur

Douglas
Well

number

$24 \mathrm{~S} 18 \mathrm{E} 28 \mathrm{CDD}$

$31 \mathrm{~S} 15 \mathrm{~W}$ 19BDB

$32 \mathrm{~S} 11 \mathrm{~W} 30 \mathrm{BBA}$

$32 \mathrm{~S} 12 \mathrm{~W}$ 04DBC

33S $11 \mathrm{~W} 28 \mathrm{CBB}$

$34 \mathrm{~S}$ 15W 17ADA

$35 \mathrm{~S} 15 \mathrm{~W} 11 \mathrm{CB}$

$18 \mathrm{C} 15 \mathrm{~W} 28 \mathrm{CCC} 3$

25S 24E 36AAC

33S 25E O9DAD $34 \mathrm{~S} 25 \mathrm{E}$ 13BAC

03S 37W 19BBC

03S 39W 32BDB

05S 38W 22ACB

05S 40W 14BCD

05S 42W $14 C B C$

30S 23W 06AAA

$33 \mathrm{~S} 22 \mathrm{~W} 30 \mathrm{CBC}$

06C 01E 02BCD

06S 02E 29DAC

O8S 02E 02CCA

05S 02W 01BAC Q

$31 \mathrm{~S} 18 \mathrm{~W} 19 \mathrm{ACB}$

29S 23E 24DBA

30S 24E 19ADD

01S 29W 19BDD

02S 29W 24BCC

03S 29W 12BBA

04S 26W 08DDD

12S 19E 13ADA

$12 S$ 20E 07CBC

$12 \mathrm{~S} 20 \mathrm{E} 17 \mathrm{CCB}$

$13 S 21 E$ 05DBB

15E 19E 15AAD
Water-

level

notes

Q

A

Q

Q

Q

A

A

Q

Q

Q

B

$Q$
$Q$
$Q$
$Q$
$Q$

Q

Q

Q
Q
Q

Q

Q

Q
$Q$
$Q$
$Q$

$Q$
$Q$
$R$
$Q$
$Q$
Well

number

23S 19W 22CCC 24S 17W 24DDD

24S 18W 36DDC

24S 19W 34ADD

25S 16W 31DAD

25S 18W O9AAA

25S 18W 33CDC

26S 19W $12 \mathrm{ABB} 2$

Ellis

14S 18W 12AAD

$14 \mathrm{~S} 18 \mathrm{~W} 12 \mathrm{ABB}$

Ellsworth

17S 09W 20BCD

$17 \mathrm{~S} 09 \mathrm{~W} 21 \mathrm{BCC}$

$17 \mathrm{~S}$ 09W $21 \mathrm{BCC} 2$

$17 \mathrm{~S}$ 09W 28CBB

$17 S$ 09W 28CBB2

17S 09W 31AAB

$17 \mathrm{~S}$ 09W 31AAB2

$17 S$ 09W 31ADC

Finney

21S 32W 20CBC

21S $34 \mathrm{~W} 14 \mathrm{DBB}$

22S 27W 14ADC

22S 33W 22BAA

22S 33W 36AAA2

22S 34W 26ADD

23S $27 W 12 C C C$

23S 33W 17BBB

23S 33W 28CDC

23S 34W 21DDC

$24 \mathrm{~S} 31 \mathrm{~W} 27 \mathrm{CCB}$

24S 32W 03DAC

24S 33W 09CCD

24S 33W 09CCD2

24S 33W 22DCA

24S 33W 28DAA

25S 32W 31DD

25S 33W 05ABD

25S 33W 09ABD

25S 33W 15DAC

$25 \mathrm{~S} 33 \mathrm{~W}$ 17DBD

25S 33W 35DBD

25S 34W 06AAA

25S 34W 10ABB

$25 \mathrm{~S} 34 \mathrm{~W} 34 \mathrm{DBD}$

$26 \mathrm{~S} 33 \mathrm{~W} 26 \mathrm{ABB}$
Water-

level

notes

$Q$
$Q$
$Q$
$Q$
$Q$
$Q$
$Q$
$Q$

Q

Q

Q

Q

Q

Q

0

Q

Q

Q

Q

Q

Q

Q

Q

Q

Q

Q

R

Q

Q

R

R

Q

Q

Q

Q

Q

Q

Q

Q

Q

Q

Q 
Table 3.--Ground-water-level observation wells--Continued

County

Ford

Geary

Gove

Graham

Grant

$\begin{array}{cc}\text { Well } & \text { Water- } \\ \text { number } & \text { level } \\ \text { notes }\end{array}$

25S 22W 20AAA

25S 22W 27CCD

25S 23W 11CCC

25S 23W $12 \mathrm{BBB}$

25S 23W $14 A D D$

26S 21W $17 D B C$

26S 21W 23ADA

26S 23W 10DAD

26S 24W 29DDD

26S 24W 31DDA

26S 24W 32CBA

26S 24W 32DDA

26S 24W 33CDA

$26 \mathrm{~S} 25 \mathrm{~W} 34 \mathrm{BBB}$

26S 26W 32DCC

$27 \mathrm{~S} 23 \mathrm{~W} 24 \mathrm{BCB}$

27S 24W 03BBD

27S 24W 03CDD

$27 \mathrm{~S} 24 \mathrm{~W} 04 \mathrm{BBC}$

27S 24W O9AAD

27S 24W 16BDB

$28 \mathrm{~S} 24 \mathrm{~W}$ 08DCC

28S 25W 06ABB

28S 26W 13CAA

29S 21W 05BBB

29S 26W 29ABB

$11 S$ 06E 27CBB

11S 26W 04CDC Q

11S 27W 16AAA Q

$11 \mathrm{~S} 27 \mathrm{~W} 26 \mathrm{BCC}$

11S 29W 04DAD

$11 \mathrm{~S} 30 \mathrm{~W} 27 \mathrm{ABB}$

06S 23W 12CCB A

06S 24W 28BAB

06S 24W 35DDD

06S 25W 28CBC

08S 23W 24BBD

27S 35W 17ADD

$27 S 37 W$ Q4ABB

$27 \mathrm{~S} 38 \mathrm{~W} 15 \mathrm{BBB}$

$27 \mathrm{~S} 38 \mathrm{~W} 23 \mathrm{CB}$

$27 \mathrm{~S} 38 \mathrm{~W} 32 \mathrm{BCC}$
County

Grant

(continued)

28S 36W 21CDD

28S 37W 02BBB3

28S 38W 07BBB

28S 38W 12DDD

28S 38W 17AAA

$28 \mathrm{~S} 38 \mathrm{~W} 33 \mathrm{BD} 3$

29S 35W 06BAA

29S 38W 35CCD

$30 \mathrm{~S} 36 \mathrm{~W}$ 01BBB

$30 \mathrm{~S} 36 \mathrm{~W} 32 \mathrm{BBC}$

$30 \mathrm{~S} 37 \mathrm{~W}$ 03DBA

$30 S 37 W 20 C B C$

Gray

24S 28W 36ACA

24S 30W 15CCC

26S 29W 35CCC

27S 27W 25CCD

$27 \mathrm{~S} 30 \mathrm{~W} 23 \mathrm{BB}$

28S 30W 17BBA

$28 \mathrm{~S} 30 \mathrm{~W} 24 \mathrm{BAB}$

29S 28W 28CDC

29S 29W 10BBB

Greeley

$16 \mathrm{~S} 39 \mathrm{~W}$ 02BDC

$16 \mathrm{~S} 39 \mathrm{~W} 22 \mathrm{DCB}$

$16 \mathrm{~S}$ 40W 18DBA

$16 \mathrm{~S} 41 \mathrm{~W}$ 20BAD

17S 39W 02BAA

$17 \mathrm{~S} 39 \mathrm{~W} 22 \mathrm{ABB}$

175 40W 15CCB

175 40W 31BBA

$17 \mathrm{~S} 42 \mathrm{~W} 27 \mathrm{CBB}$

Hamilton

24S 40W 17BBB

$26 \mathrm{~S} 42 \mathrm{~W} 17 \mathrm{CB}$

26S $42 \mathrm{~W} 22 \mathrm{CDB}$

Harvey

Haskel1

24S 02W 16BAA

27S 33W 29DAA $27 \mathrm{~S} 34 \mathrm{~W}$ 16DDD3

$28 \mathrm{~S} 32 \mathrm{~W} 18 \mathrm{BBB}$

$28 \mathrm{~S} 32 \mathrm{~W} 24 \mathrm{BCC}$

$28 \mathrm{~S} 33 \mathrm{~W} 21 \mathrm{BCC}$

29S 32W 26CBB2
Water-

level

notes

$Q$
$Q$
$Q$
$Q$
$Q$
$Q$
$Q$
$Q$
$Q$
$Q$
$Q$
$Q$

$Q$
$Q$
$Q$
$Q$
$Q$
$Q$
$Q$
$Q$
$Q$

$Q$
$Q$
$Q$
$Q$
$Q$
$Q$
$Q$
$Q$
$Q$

Q

Q

Q

Q

Q Q Q Q Q Q 
Table 3.--Ground-water-level observation wells--Continued

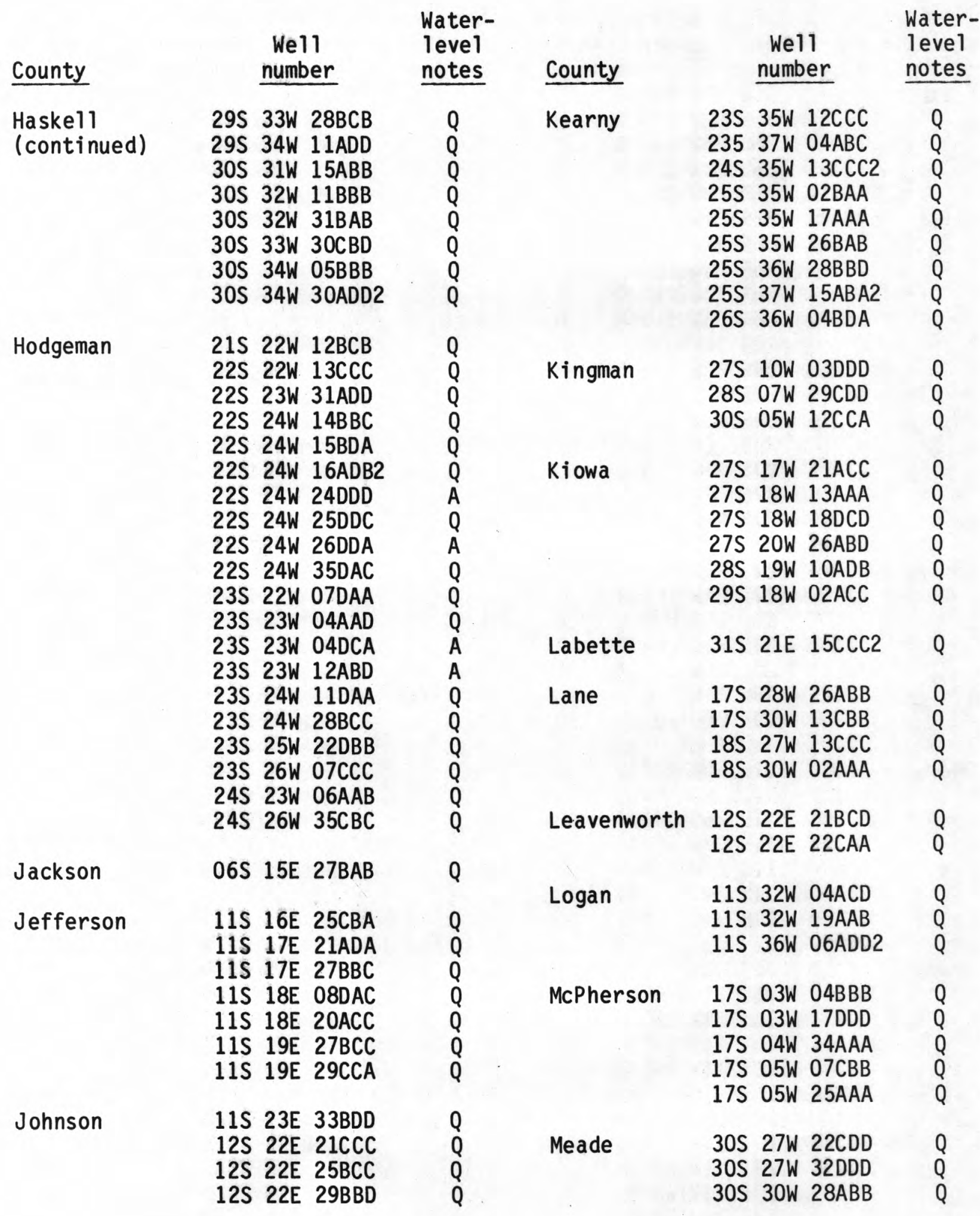


Table 3.--Ground-water-1evel observation wells--Continued

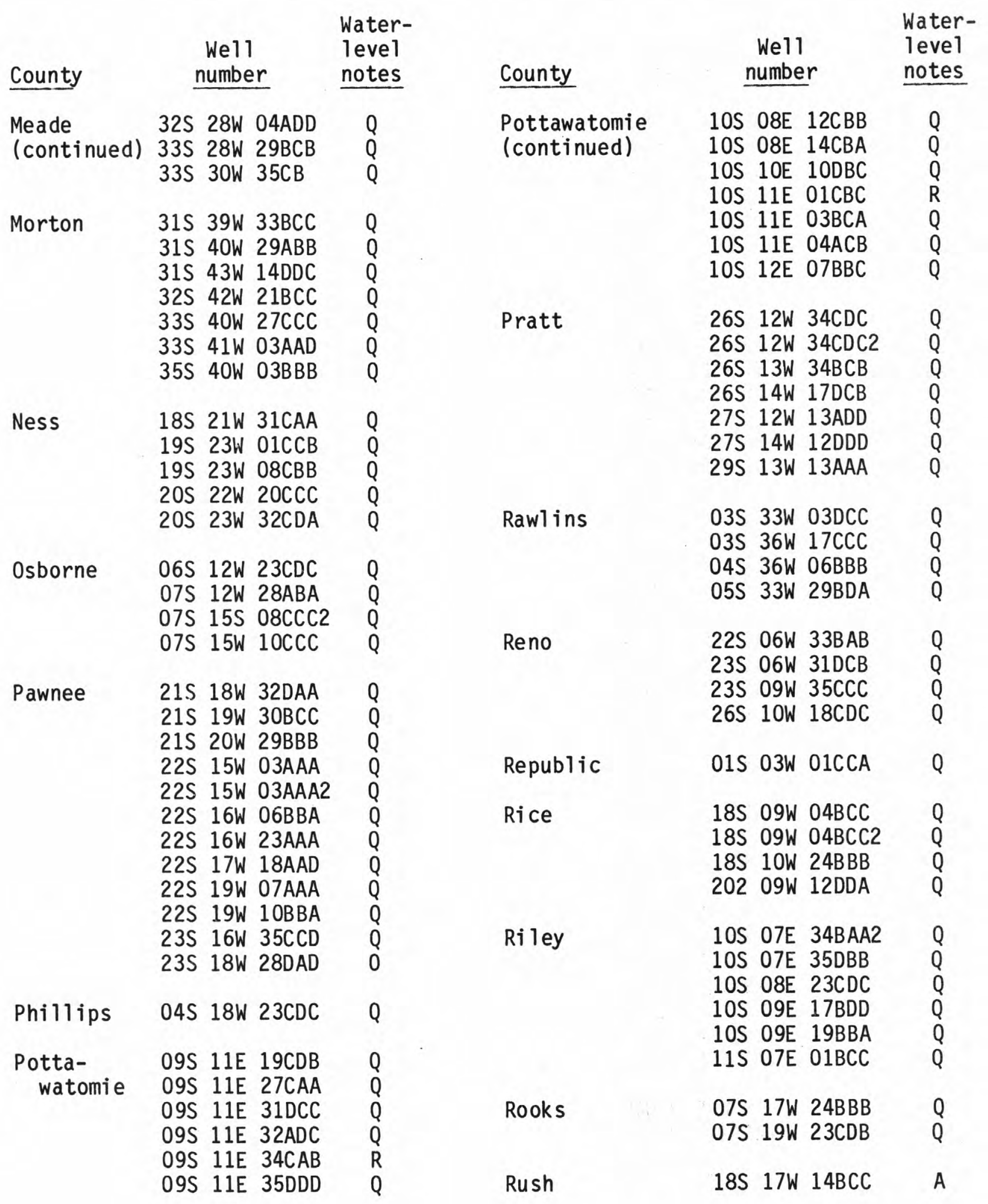


Table 3.--Ground-water-level observation wells--Continued

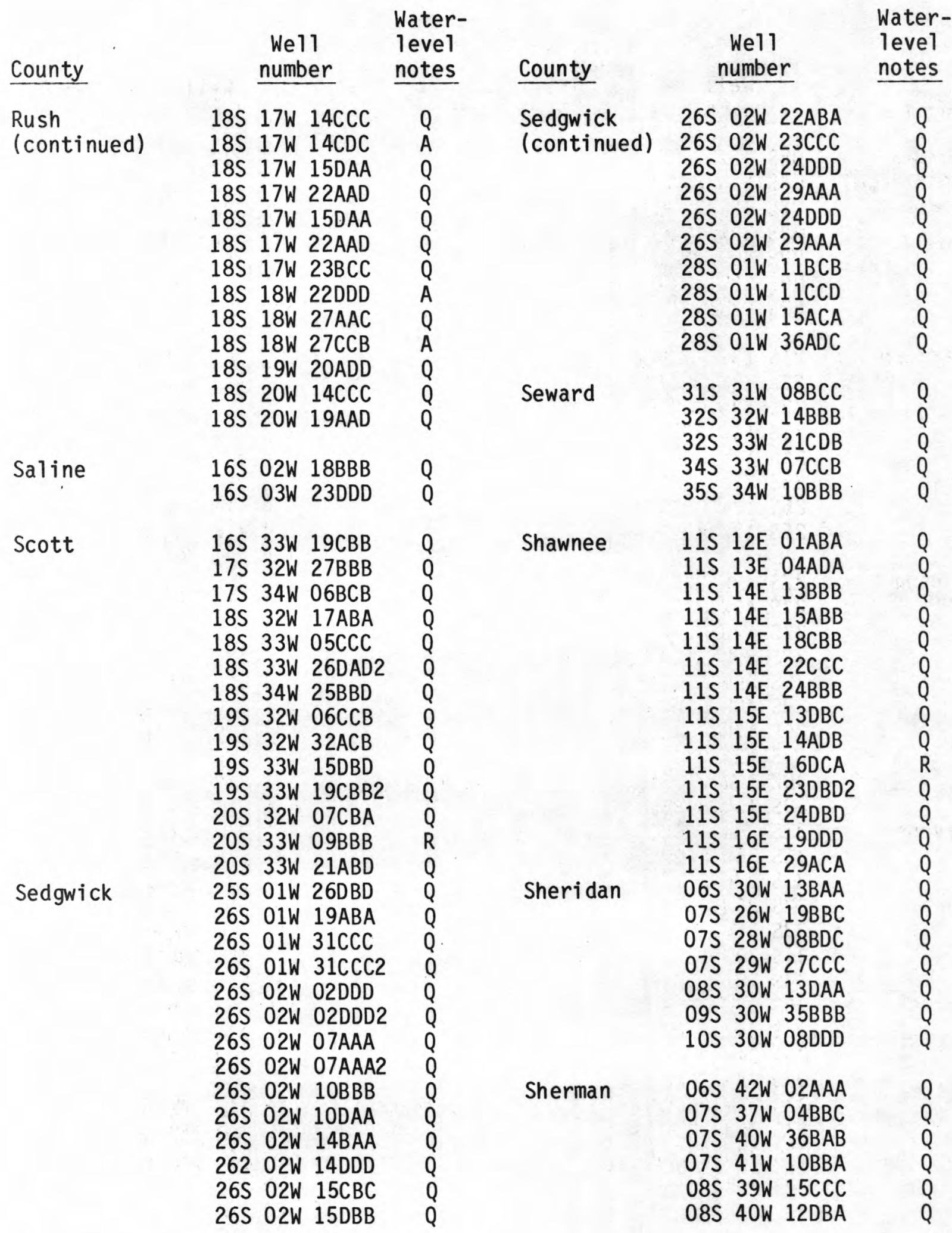


Table 3.--Ground-water-1 evel observation wells--Continued

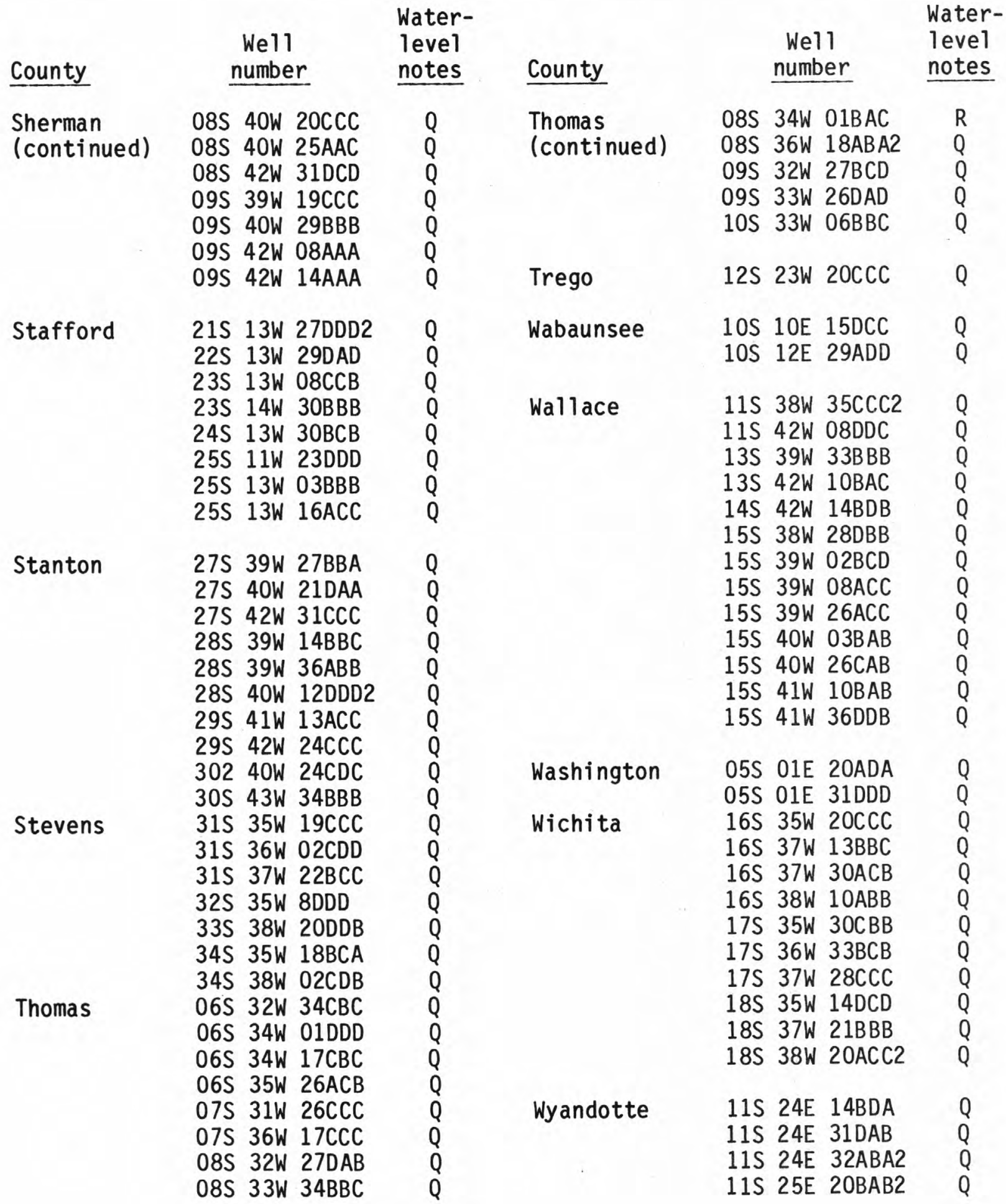


Table 4.--Surface-water-quality stations

Missouri River Basin

\begin{tabular}{|c|c|c|c|c|}
\hline $\begin{array}{l}\text { Ident. } \\
\text { no. } \\
06-\end{array}$ & Station name & $\begin{array}{l}\text { Sampling purpose } \\
\text { (frequency code) }\end{array}$ & $\begin{array}{l}\text { Coop. } \\
\text { or } \\
\text { support }\end{array}$ & Remarks \\
\hline 81557 & $\begin{array}{l}\text { Wolf R. } 3 \text { mi south of } \\
\text { Hiawatha }\end{array}$ & $\operatorname{SED}(9)$ & SCS & \\
\hline 815578 & Wolf R. at Hiawatha & $\begin{array}{l}\operatorname{SED}(9), \operatorname{CHEM}(1), \operatorname{METAL}(1), \\
\operatorname{METALB}(1), \operatorname{PEST}(1), \operatorname{PESTB}(1)\end{array}$ & SCS & \\
\hline 8156 & Wolf R. nr Hiawatha & SED (9) & $\operatorname{scs}$ & \\
\hline 8158 & Wolf R. at Leona & $\operatorname{SED}(9)$ & SCS & \\
\hline 81588 & Wolf R. nr Sparks & $\begin{array}{l}\operatorname{SED}(9), \operatorname{CHEM}(1), \operatorname{METAL}(1), \\
\operatorname{METALB}(1), \operatorname{PEST}(1), \operatorname{PESTB}(1)\end{array}$ & SCS & \\
\hline 8447 & $\begin{array}{l}\text { S. Fk. Sappa Cr. nr } \\
\text { Brewster }\end{array}$ & $\operatorname{SED}(12)$ & KWRB & \\
\hline 8465 & $\begin{array}{l}\text { Beaver } \mathrm{Cr} \text {. at Cedar } \\
\text { Bluffs }\end{array}$ & $\operatorname{SED}(12), \operatorname{BED}(2)$ & KWRB & \\
\hline 8469 & $\begin{array}{l}\text { Prairie Dog Cr. ab } \\
\text { Norton Res }\end{array}$ & $\operatorname{SED}(12)$ & KWRB & \\
\hline $\begin{array}{l}84795 \\
8538\end{array}$ & $\begin{array}{l}\text { Norton Res. nr Norton } \\
\text { White Rock Cr. nr } \\
\text { Burr Oak }\end{array}$ & $\begin{array}{l}\operatorname{CHEM}(1), \operatorname{COLI}(4), \operatorname{FIELD}(8) \\
\operatorname{SED}(12)\end{array}$ & $\begin{array}{l}\text { WPRS } \\
\text { KWRB }\end{array}$ & \\
\hline 8566 & $\begin{array}{l}\text { Republican R. at } \mathrm{Cl} \text { ay } \\
\text { Center }\end{array}$ & $\begin{array}{l}\operatorname{CHEM}(12), \operatorname{BIOL}(7), \operatorname{TOC}(12), \\
\operatorname{METAL}(4), \operatorname{COLI}(12), \operatorname{FIELD}(12), \\
\text { OBS(13) }\end{array}$ & NASQAN & MONITOR \\
\hline 8585 & $\begin{array}{l}\text { N. Fk. Smoky Hill R. nr } \\
\text { McAllaster }\end{array}$ & SED $(12)$ & KWRB & \\
\hline $\begin{array}{l}8615 \\
8635 \\
8639\end{array}$ & $\begin{array}{l}\text { Cedar Bluff Res. nr Ellis } \\
\text { Big Cr. nr Hays } \\
\text { N. Fk. Big Cr. nr } \\
\text { Victoria }\end{array}$ & $\begin{array}{l}\operatorname{CHEM}(1), \operatorname{COLI}(4), \operatorname{FIELD}(8) \\
\operatorname{SED}(12) \\
\operatorname{SED}(12)\end{array}$ & $\begin{array}{l}\text { WPRS } \\
\text { KWRB } \\
\text { KWRB }\end{array}$ & \\
\hline $\begin{array}{l}8670 \\
8695 \\
8710\end{array}$ & $\begin{array}{l}\text { Saline R. nr Russell } \\
\text { Saline R. at Tescott } \\
\text { N. Fk. Solomon R. at } \\
\text { Glade }\end{array}$ & $\begin{array}{l}\operatorname{SED}(12) \\
\operatorname{SED}(12), \operatorname{BED}(2) \\
\operatorname{SED}(12)\end{array}$ & $\begin{array}{l}\text { KWRB } \\
\text { KWRB } \\
\text { KWRB }\end{array}$ & \\
\hline $\begin{array}{l}8719 \\
8725\end{array}$ & $\begin{array}{l}\text { Deer Cr. nr Phillipsburg } \\
\text { N. Fk. Solomon R. at } \\
\text { Portis }\end{array}$ & $\begin{array}{l}\operatorname{SED}(12) \\
\operatorname{CHEM}(8), \operatorname{FIELD}(8)\end{array}$ & $\begin{array}{l}\text { KWRB } \\
\text { WPRS }\end{array}$ & \\
\hline 8730 & $\begin{array}{l}\text { S. Fk. Solomon R. at } \\
\text { Webster Res. }\end{array}$ & $\operatorname{SED}(12)$ & KWRB & \\
\hline 87346 & S. Fk. Solomon R. at & $\operatorname{CHEM}(8), \operatorname{FIELD}(8)$ & WPRS & \\
\hline 8737 & $\mathrm{Kill} \mathrm{Cr}$. nr Bloomington & $\operatorname{SED}(12)$ & KWRB & \\
\hline
\end{tabular}




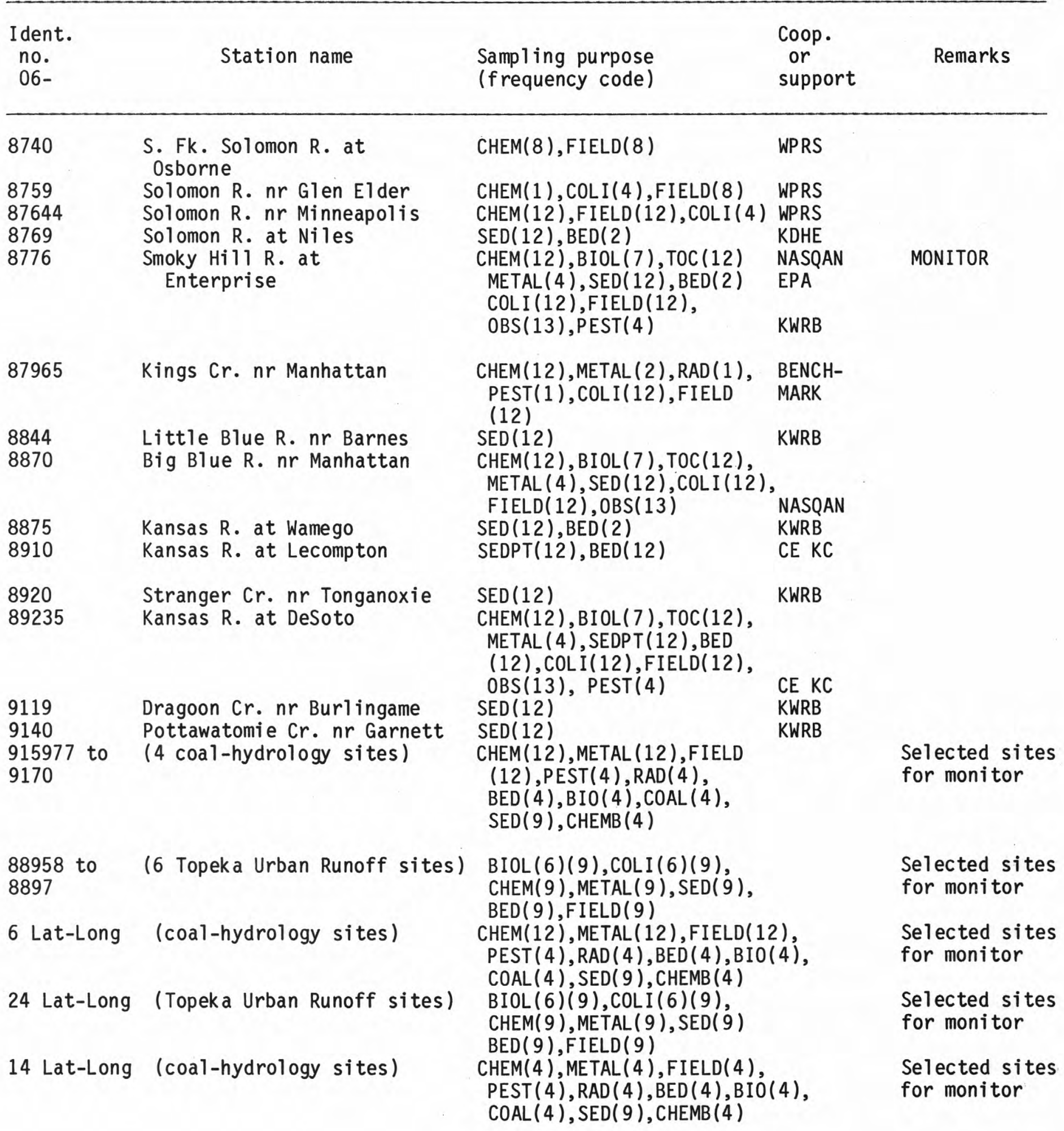


Table 4.--Surface-water-quality stations--Continued

Ident.

no.

06-

Station name

Sampling purpose

Coop.

(frequency code)

or

Remarks

Support

$\operatorname{SED}(9), \operatorname{CHEM}(1)$

SCS

of Auburn lat $38^{\prime} 57^{\circ} 18^{\prime \prime}$

long $95^{\prime} 46^{\circ} 40^{\prime \prime}$

Six mile Cr. Trib. $4 \mathrm{mi}$ NE

of Auburn lat $38^{\prime} 56^{\circ} 32^{\prime \prime}$

long $95^{\prime} 46^{\circ} 40^{\prime \prime}$

Wakarusa R. 4 mi W of Auburn

lat $38^{\prime} 53^{\circ} 50^{\circ}$ long

$95^{\prime} 52^{\circ} 53^{\prime \prime}$

Wakarusa R. 5 mi $W$ of Auburn lat $38^{\prime} 53^{\circ} 51^{\prime \prime}$ long $95^{\prime} 54^{\circ} 29^{\prime \prime}$

Pony $\mathrm{Cr}$. $\mathrm{nr}$ Reserve lat $40^{\prime} 00^{\circ} 01^{\prime \prime}$ long $95^{\prime} 37^{\circ} 40^{\prime \prime}$

Pony Cr. nr Morrill lat $39^{\prime} 57^{\circ} 56^{\prime \prime}$ long $95^{\prime} 41^{\circ} 34^{\prime \prime}$

$\operatorname{SED}(9), \operatorname{CHEM}(1)$

SCS

$\operatorname{SED}(9), \operatorname{CHEM}(1)$

SCS

$\operatorname{SED}(9), \operatorname{CHEM}(1)$

SCS

$\operatorname{SED}(9), \operatorname{CHEM}(2), \operatorname{METAL}(1), \quad \operatorname{SCS}$ $\operatorname{METALB}(1), \operatorname{PEST}(1)$,

PESTB(1)

$\operatorname{SED}(9), \operatorname{CHEM}(2), \operatorname{METAL}(1), \quad \operatorname{SCS}$

$\operatorname{METALB}(1), \operatorname{PEST}(1)$,

PESTB (1)

Pony $\mathrm{Cr}$. $\mathrm{nr}$ Sabetha

lat $39^{\prime} 57^{\circ} 10^{\prime \prime}$ long $95^{\prime} 46^{\circ} 08^{\prime \prime}$

$\operatorname{SED}(9), \operatorname{CHEM}(2), \operatorname{METAL}(1), \quad \operatorname{SCS}$

$\operatorname{METALB}(1), \operatorname{PEST}(1)$,

PESTB (1)

Pony $\mathrm{Cr}$. at Sabetha

lat $39^{\prime} 55^{\circ} 51^{\prime \prime}$ long $95^{\prime} 47^{\circ} 16^{\prime \prime}$

$\operatorname{SED}(9), \operatorname{CHEM}(2), \operatorname{METAL}(1), \quad \operatorname{SCS}$

$\operatorname{METALB}(1), \operatorname{PEST}(1), \operatorname{PESTB}(1)$ 
Table 4.--Surface-water-quality stations--Continued

\begin{tabular}{|c|c|c|c|c|}
\hline $\begin{array}{l}\text { Ident. } \\
\text { no. } \\
07-\end{array}$ & Station name & $\begin{array}{l}\text { Sampling purpose } \\
\text { (frequency code) }\end{array}$ & $\begin{array}{l}\text { Coop. } \\
\text { or } \\
\text { support }\end{array}$ & Remarks \\
\hline
\end{tabular}

\section{Arkansas River Basin}

1375 Arkansas R. nr Coolidge

1380 Arkansas R. at Syracuse

13865 Whitewoman $\mathrm{Cr}$. $\mathrm{nr}$ Leoti

1398 Mulberry $\mathrm{Cr}$. nr Dodge City

1400 Arkansas R. nr Kinsley

1412 Pawnee R. nr Larned

1419 Walnut $\mathrm{Cr}$. at Albert

1423 Rattlesnake Cr. nr Macksville

14286

1429

1433 Cow Cr. nr Lyons

14333 Arkansas R. nr Hutchinson

143665 Little Ark. R. at Alta Mills

1442 Little Ark. R. at Valley Ctr.

14478 N. Fk. Ninnescah R. at Cheney Res.

14491 S. Fk. Ninnescah R. at Pratt

1452 S. Fk. Ninnescah R. nr Murdock

1455

1457

1465
Ninnescah R. nr Peck

Slate Creek at Wellington

Arkansas R. at Arkansas City
14707 Whitewater R. at Towanda

1478 Walnut R. at Winfield

15601 N. Fk. Cimarron R. at Richfield

15622 Bear $\mathrm{Cr}$. nr Johnson

1575 Crooked $\mathrm{Cr}$. nr Nye

1579 Cavalry $\mathrm{Cr}$. at Coldwater

1675 Otter Cr. at Climax

1698 Elk R. at Elk Falls
$\operatorname{CHEM}(12), \operatorname{BIOL}(7), \operatorname{TOC}(12)$, NASQAN
$\operatorname{METAL}(4), \operatorname{PEST}(4)$,

MONITOR

$\operatorname{METAL}(4), \operatorname{PEST}(4)$,
$\operatorname{COLI}(12), \operatorname{FIELD}(12)$,

SED (12)

$\operatorname{SED}(12), \operatorname{BED}(2), \quad$ KWRB

$\operatorname{SED}(12), B E D(12) \quad K W R B$

SED (12)

$\operatorname{SED}(12), B E D(2)$

KWRB

KWRB

$\operatorname{SED}(12)$

$\operatorname{SED}(12), \operatorname{BED}(2)$

KWRB

SED (12)

$\operatorname{SED}(12)$

SED (12)

KWRB

KWRB

KWRB

KWRB

SED (12) KWRB

SED (12), BED (2) KWRB

$\operatorname{SED}(12)$

SED (12)

KWRB

CE T

KWRB

1,6

$\operatorname{SED}(12)$

KWRB

$\operatorname{SED}(12), \operatorname{BED}(2) \quad$ KWRB

$\operatorname{SED}(12), B E D(2) \quad$ KWRB

$\operatorname{SED}(12)$

KWRB

CHEM(12), BIOL (7), TOC (12), $\operatorname{METAL}(4), \operatorname{RAD}(6)(9)(2)$, $\operatorname{PEST}(4), \operatorname{SED}(12), \mathrm{BED}(2)$ COLI(12), FIELD(12), OBS(13)

CE T-

NASQAN-

KWRB

$\operatorname{SED}(12)$

KWRB

$\operatorname{SED}(12)$

SED (12)

KWRB

KWRB

$\operatorname{SED}(12), \operatorname{BED}(12) \quad$ KWRB

SED (12)

KWRB

$\operatorname{SED}(12), \operatorname{BED}(2)$

$\operatorname{SED}(12)$

$\operatorname{SED}(12)$
1,4
CE T

CE T 
Table 4.--Surface-water-quality stations--Continued

\begin{tabular}{|c|c|c|c|c|}
\hline $\begin{array}{l}\text { Ident. } \\
\text { no. } \\
07-\end{array}$ & Station name & $\begin{array}{l}\text { Sampling purpose } \\
\text { (frequency code) }\end{array}$ & $\begin{array}{l}\text { Coop. } \\
\text { or } \\
\text { support }\end{array}$ & Remarks \\
\hline $\begin{array}{l}1707 \\
1795 \\
17973 \\
179795 \\
18225\end{array}$ & $\begin{array}{l}\text { Big Hill Cr. nr Cherryvale } \\
\text { Neosho R. at Council Grove } \\
\text { Neosho R. nr Americus } \\
\text { Cottonwood R. bl Marion Lake } \\
\text { Cottonwood R. nr Plymouth }\end{array}$ & $\begin{array}{l}\operatorname{SED}(12) \\
\operatorname{SED}(12) \\
\operatorname{SED}(12) \\
\operatorname{SED}(12) \\
\operatorname{SED}(12)\end{array}$ & $\begin{array}{ll}\text { CE } & \text { T } \\
\text { CE } & \text { T } \\
\text { CE } & \text { T } \\
\text { CE } & \text { T } \\
\text { CE } & \text { T }\end{array}$ & $\begin{array}{l}1 \\
1,2 \\
1,8 \\
1,2 \\
1,2\end{array}$ \\
\hline 1835 & Neosho R. nr Parsons & $\begin{array}{l}\operatorname{CHEM}(12), \operatorname{BIOL}(7), \operatorname{TOC}(12), \\
\operatorname{METAL}(4), \operatorname{SED}(12), \\
\operatorname{COLI}(12), \operatorname{FIELD}(12)\end{array}$ & $\begin{array}{l}\text { NASQAN- } \\
\text { KWRB }\end{array}$ & MONITOR \\
\hline 1840 & Lightning $\mathrm{Cr}$. nr McCune & SED(12) & KWRB & \\
\hline
\end{tabular}


Table 5.--Ground-water-quality sampling sites

\begin{tabular}{|c|c|c|c|c|}
\hline County & $\begin{array}{c}\text { Wel1 } \\
\text { number }\end{array}$ & County & & $\begin{array}{c}\text { Wel1 } \\
\text { number } \\
\end{array}$ \\
\hline Allen & $\begin{array}{lll}24 \mathrm{~S} & 17 \mathrm{E} & 26 \mathrm{BBD} \\
24 \mathrm{~S} & 20 \mathrm{E} & 35 \mathrm{CDD} \\
25 \mathrm{~S} & 18 \mathrm{E} & 07 \mathrm{AAB} \\
26 \mathrm{~S} & 18 \mathrm{E} & 13 \mathrm{CBC}\end{array}$ & Chase & $\begin{array}{l}19 S \\
19 S \\
20 S \\
22 S\end{array}$ & $\begin{array}{ll}\text { 08E } & \text { 20AAA } \\
\text { 09E } & \text { 26DAA } \\
\text { O7E } & \text { 27DAA } \\
\text { 08E } & \text { 05CCA }\end{array}$ \\
\hline Anderson & $\begin{array}{lll}20 S & 20 E & 05 A D D \\
21 S & 18 E & 05 D C A 2 \\
22 S & 20 E & 18 A A A\end{array}$ & Chautauqua & $\begin{array}{l}32 S \\
34 S \\
35 S\end{array}$ & $\begin{array}{ll}10 \mathrm{E} & 19 \mathrm{DDD} \\
10 \mathrm{E} & 16 \mathrm{DDC} \\
13 \mathrm{E} & 17 \mathrm{BBA}\end{array}$ \\
\hline Atchison & $\begin{array}{lll}05 \mathrm{~S} & 20 \mathrm{E} & 18 \mathrm{CDC} \\
06 \mathrm{~S} & 17 \mathrm{E} & 31 \mathrm{DAA} \\
06 \mathrm{~S} & 18 \mathrm{E} & 22 \mathrm{BCD} \\
07 \mathrm{~S} & 18 \mathrm{E} & 24 \mathrm{BAA}\end{array}$ & Cherokee & $\begin{array}{l}32 S \\
33 S \\
34 S \\
35 S\end{array}$ & $\begin{array}{ll}25 E & 07 A A A \\
22 E & 19 D A A \\
23 E & 02 A B A \\
25 E & 04 C C C\end{array}$ \\
\hline Barber & $\begin{array}{lll}32 C & 12 W & 05 D B D \\
33 S & 11 W & 33 A B B \\
34 S & 10 W & 16 C A B \\
35 S & 12 W & 08 B A C\end{array}$ & Cheyenne & $\begin{array}{l}01 S \\
04 S \\
04 S \\
05 S \\
05 S\end{array}$ & $\begin{array}{ll}38 W & 09 A B B \\
39 W & 15 C C A \\
41 W & 16 D A A \\
38 W & 22 A C B \\
42 W & 14 C B C\end{array}$ \\
\hline Barton & $\begin{array}{lll}18 S & 15 W & 30 A C A \\
19 S & 12 W & 05 D D C \\
19 S & 12 W & 13 A D A \\
20 S & 13 W & 30 C A B \\
20 S & 14 W & 27 B C A\end{array}$ & Clark & $\begin{array}{l}30 S \\
31 S \\
32 S \\
33 S \\
34 S\end{array}$ & $\begin{array}{ll}23 W & 05 D B B \\
23 W & 07 B B A \\
23 W & 26 D D D \\
22 W & 30 C B C \\
25 W & 36 B A D\end{array}$ \\
\hline Bourbon & $\begin{array}{lll}23 S & 22 E & 29 A A A \\
24 S & 23 E & 04 D B \\
26 S & 25 E & 35 C C B\end{array}$ & Clay & $\begin{array}{l}07 S \\
08 S \\
10 S \\
10 S\end{array}$ & $\begin{array}{ll}\text { O4E } & 20 A D C \\
02 E & 11 A D B \\
01 E & 17 D C C \\
04 E & 06 B C D\end{array}$ \\
\hline Brown & $\begin{array}{lll}01 S & 17 E & 07 C B C \\
02 S & 18 E & 14 C A D \\
03 S & 17 E & 30 B B B\end{array}$ & Cloud & $\begin{array}{l}05 S \\
05 S \\
06 S \\
08 S\end{array}$ & 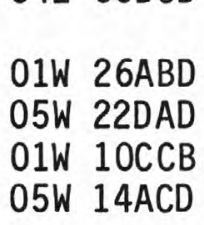 \\
\hline Butler & $\begin{array}{lll}23 S & 07 E & 10 B B B \\
24 S & 04 E & 29 D B A 2 \\
25 S & 06 E & 23 D D B \\
26 S & 04 E & 08 D C D \\
27 S & 04 E & 22 B A C \\
28 S & 05 E & 32 C D C \\
29 S & 07 E & 07 D D A\end{array}$ & $\begin{array}{l}\text { Coffey } \\
\text { Comanche }\end{array}$ & $\begin{array}{l}19 S \\
21 S \\
22 S \\
31 S \\
32 S \\
32 S \\
33 S\end{array}$ & $\begin{array}{ll}15 \mathrm{E} & 13 \mathrm{AAB} \\
15 \mathrm{E} & 16 \mathrm{CDD} \\
14 \mathrm{E} & 30 \mathrm{AAA} \\
& \\
19 \mathrm{~W} & 24 \mathrm{AAB} \\
19 \mathrm{~W} & 12 \mathrm{DA} \\
20 \mathrm{~W} & 18 \mathrm{AAA} \\
19 \mathrm{~W} & 36 \mathrm{DAA}\end{array}$ \\
\hline
\end{tabular}


Table 5.--Ground-water-quality sampling sites--Continued

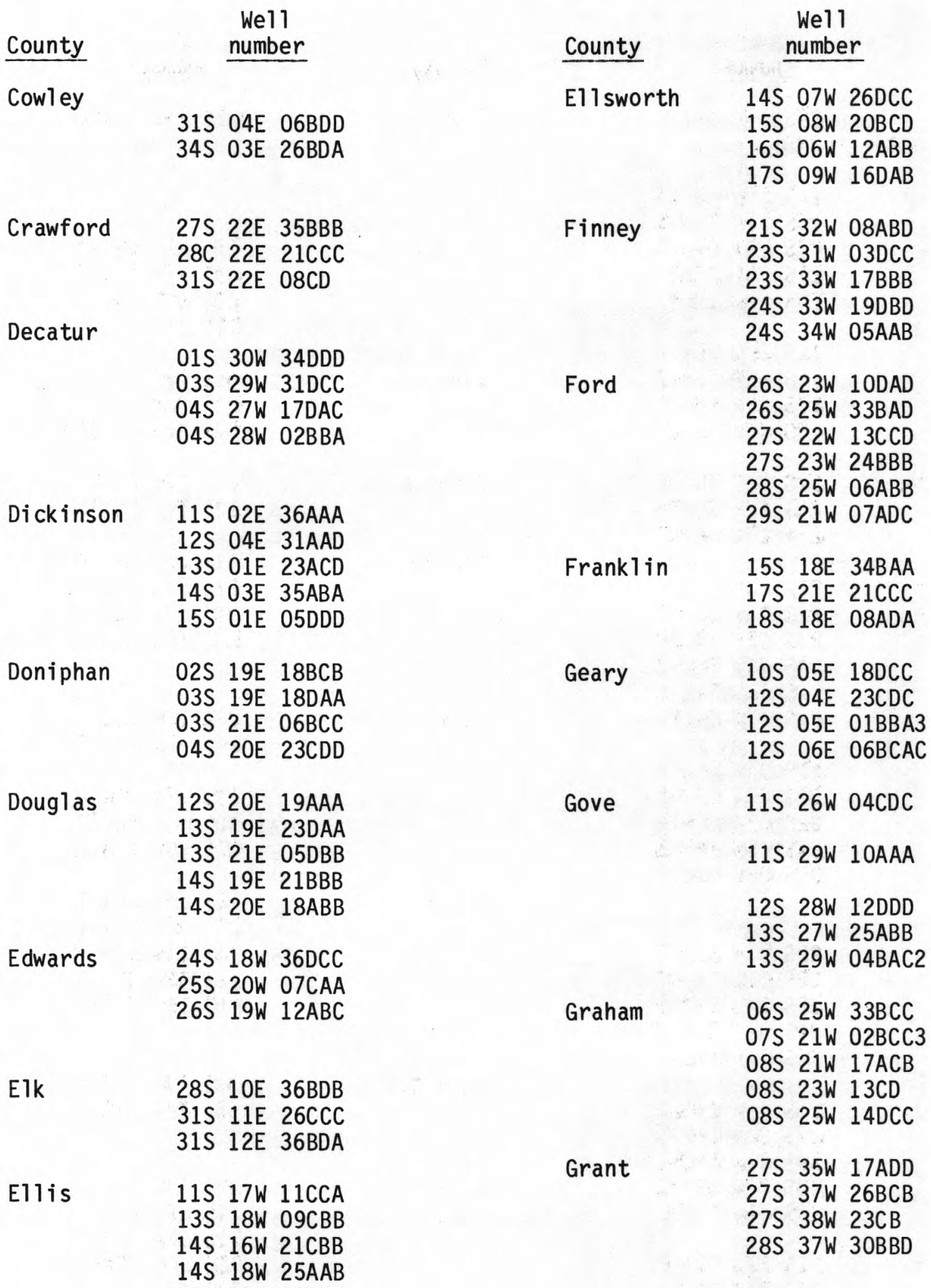


Table 5.--Ground-water-quality sampling sites--Continued

\begin{tabular}{|c|c|c|c|}
\hline County & $\begin{array}{c}\text { We11 } \\
\text { number }\end{array}$ & County & $\begin{array}{c}\text { Well } 1 \\
\text { number } \\
\end{array}$ \\
\hline $\begin{array}{l}\text { Grant } \\
\text { (continued) }\end{array}$ & $\begin{array}{lll}29 S & 35 W & 06 B A A \\
30 S & 38 W & 13 C C C\end{array}$ & Jackson & 07S 13E 10BBB \\
\hline Gray & 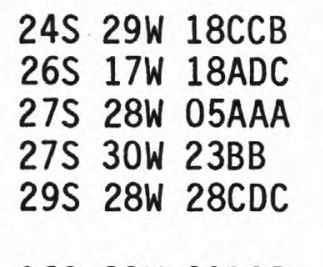 & Jefferson & $\begin{array}{lll}08 S & 17 E & 09 A A A \\
09 S & 17 E & 18 C B B \\
09 S & 19 E & 34 C C C \\
11 S & 16 E & 13 C B D\end{array}$ \\
\hline Greeley & $\begin{array}{lll}16 S & 39 W & 22 D C B \\
16 S & 41 W & 20 B A D \\
17 S & 40 W & 15 C C B \\
20 S & 41 W & 02 A D D\end{array}$ & Jewell & $\begin{array}{lll}02 S & 09 W & 23 B A C \\
03 S & 06 W & 21 C A B \\
04 S & 08 W & 25 D A B 2\end{array}$ \\
\hline Greenwood & $\begin{array}{lll}22 S & 13 E & 20 D D C \\
25 S & 13 E & 30 C C A \\
26 A & 10 E & 04 C C C\end{array}$ & Johnson & $\begin{array}{lll}12 S & 24 E & 05 D C D \\
13 S & 21 E & 26 C C D\end{array}$ \\
\hline \multirow[t]{2}{*}{ Hami 1ton } & 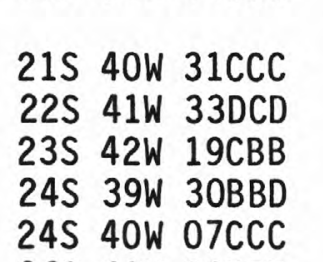 & Kearny & $\begin{array}{lll}21 S & 37 W & 02 C D D \\
23 S & 35 W & 25 B B B 2 \\
23 S & 37 W & 28 C C B \\
26 S & 37 W & 21 D D D\end{array}$ \\
\hline & $26 S 41 W 20 B B D$ & Kingman & $\begin{array}{lll}27 S & 10 W & 32 D C C \\
28 S & 06 W & 12 C D D\end{array}$ \\
\hline \multirow[t]{2}{*}{ Harper } & $\begin{array}{lll}31 S & 05 W & 25 D C C \\
32 S & 07 W & 02 C D A \\
32 S & 08 W & 20 B D D \\
34 S & 09 W & 18 B B B \\
35 S & 05 W & 11 C C C 2\end{array}$ & & $\begin{array}{lll}29 S & 07 W & 26 A D B \\
30 S & 05 W & 12 C C A \\
30 S & 09 W & 10 A D C\end{array}$ \\
\hline & & Kiowa & $\begin{array}{lll}27 S & 19 W & 30 B B D \\
27 S & 20 W & 26 A B D\end{array}$ \\
\hline Harvey & $\begin{array}{lll}22 S & 01 W & 30 D C C \\
23 S & 01 W & 32 B B C \\
23 S & 03 W & 29 D B D \\
24 S & 02 W & 02 A A C \\
24 S & 02 W & 23 B B B\end{array}$ & & $\begin{array}{lll}28 S & 16 W & 02 C C A \\
28 S & 18 W & 19 C C B \\
28 S & 19 W & 31 B B B\end{array}$ \\
\hline Haskel1 & $\begin{array}{lll}27 S & 31 W & 24 C D C \\
27 S & 32 W & 06 C B B \\
29 S & 34 W & 36 C B C\end{array}$ & Labette & $\begin{array}{lll}33 S & 18 E & 10 B B B \\
33 S & 20 E & 09 D D D\end{array}$ \\
\hline & $\begin{array}{lll}30 S & 33 W & 02 A A B \\
30 S & 34 W & 13 A B C\end{array}$ & Lane & $\begin{array}{lll}16 S & 29 W & 26 C C C \\
17 S & 27 W & 20 C C C \\
18 S & 28 W & 18 A C C\end{array}$ \\
\hline Hodgeman & $\begin{array}{lll}21 S & 22 W & 03 A B B \\
22 S & 24 W & 34 C D C \\
23 S & 23 W & 06 C A B\end{array}$ & & $\begin{array}{lll}18 S & 30 W & 02 A A A \\
20 S & 29 W & 03 C C B\end{array}$ \\
\hline
\end{tabular}


Table 5.--Ground-water-quality sampling sites--Continued

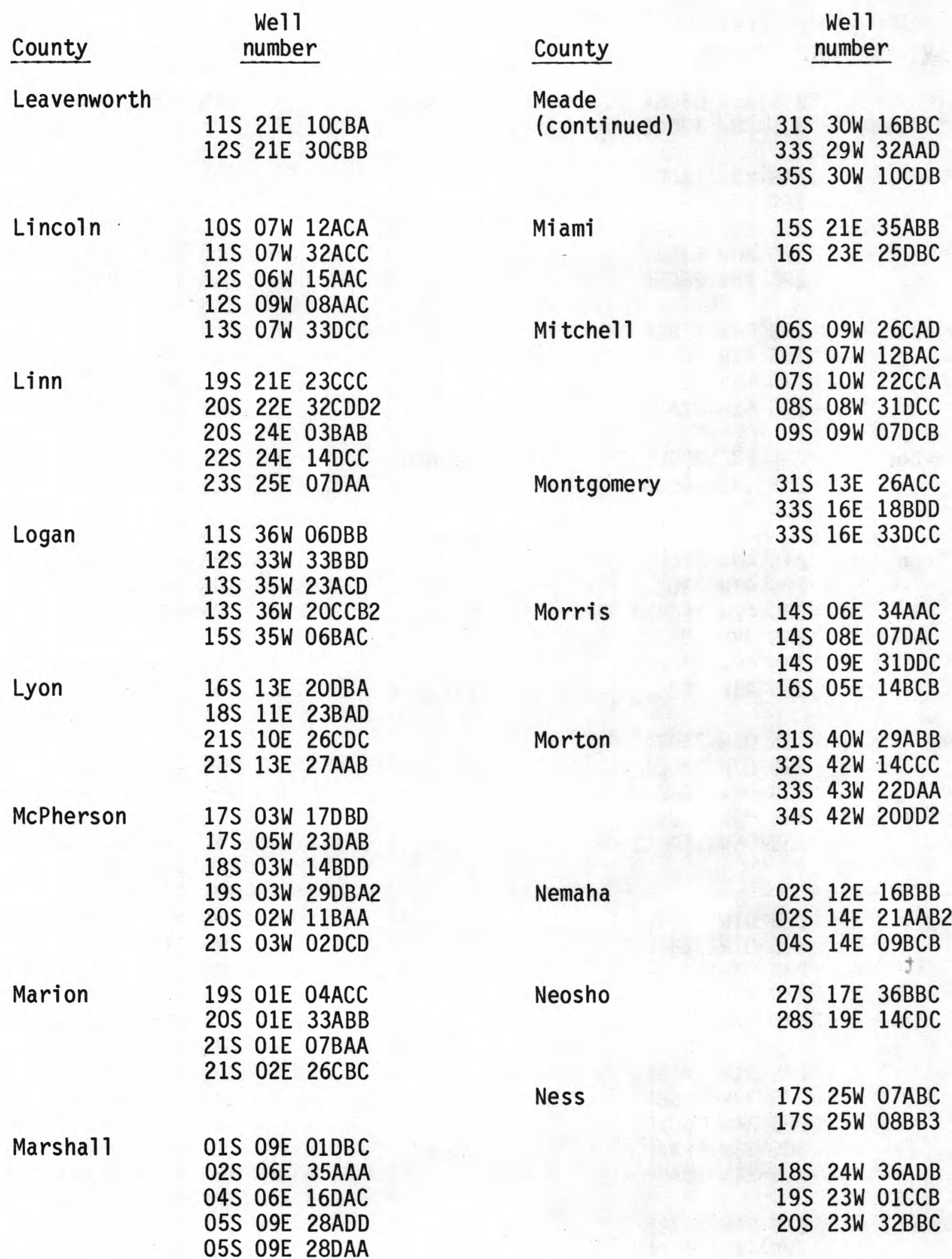

Meade

$30 S$ 26W 07BBB 
Table 5.--Ground-water-quality sampling sites--Continued

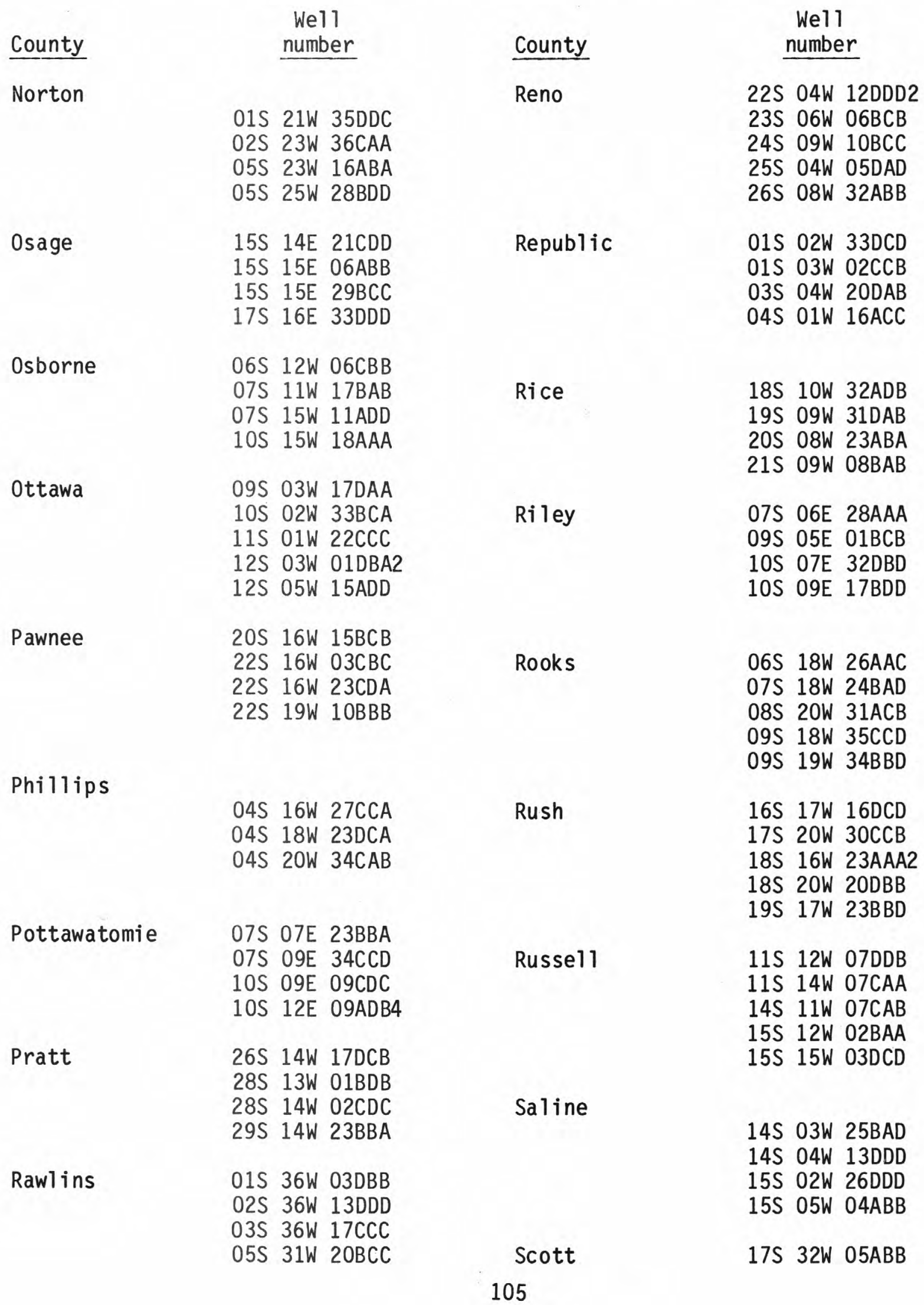


Table 5.--Ground-water-quality sampling sites--Continued

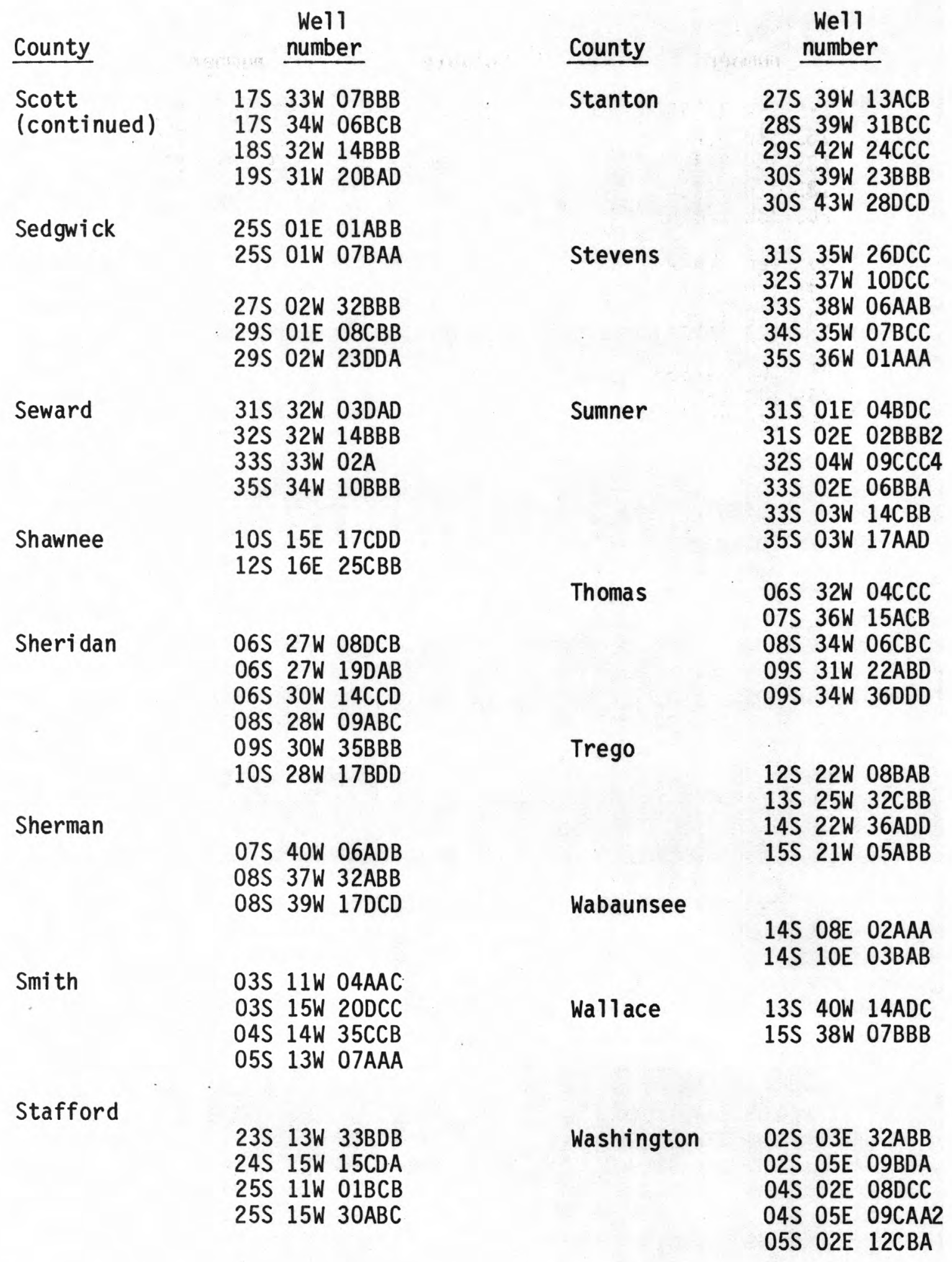


Table 5.--Ground-water-quality sampling sites--Continued

\begin{tabular}{|c|c|c|c|}
\hline County & $\begin{array}{c}\text { Wel1 } 1 \\
\text { number } \\
\end{array}$ & County & $\begin{array}{c}\text { Well } 1 \\
\text { number } \\
\end{array}$ \\
\hline Wichita & $\begin{array}{lll}16 S & 35 W & 31 D B A \\
16 S & 37 W & 30 A C B \\
18 S & 35 W & 34 A B B \\
18 S & 37 W & 03 C C C \\
20 S & 38 W & 17 C B D\end{array}$ & Wyandotte & $\begin{array}{lll}10 S & 23 E & 30 B B C \\
11 S & 23 E & 17 C C A \\
12 S & 23 E & 06 C B C\end{array}$ \\
\hline Wilson & $\begin{array}{lll}27 S & 14 E & 25 B B B \\
27 S & 16 E & 23 D A A \\
30 S & 16 E & 15 B C C\end{array}$ & & \\
\hline Woodson & $\begin{array}{lll}24 S & 16 E & 34 A B B \\
25 S & 14 E & 16 C C B \\
25 S & 15 E & 08 D A D\end{array}$ & & \\
\hline
\end{tabular}



